\title{
Community Based Education and professional competencies : a study of institutional structures, perspectives and practices in Pakistan
}

Citation for published version (APA):

Ladhani, Z. (2013). Community Based Education and professional competencies : a study of institutional structures, perspectives and practices in Pakistan. [Doctoral Thesis, Maastricht University]. Maastricht University. https://doi.org/10.26481/dis.20130705zl

Document status and date:

Published: 01/01/2013

DOI:

10.26481/dis.20130705zl

Document Version:

Publisher's PDF, also known as Version of record

Please check the document version of this publication:

- A submitted manuscript is the version of the article upon submission and before peer-review. There can be important differences between the submitted version and the official published version of record.

People interested in the research are advised to contact the author for the final version of the publication, or visit the DOI to the publisher's website.

- The final author version and the galley proof are versions of the publication after peer review.

- The final published version features the final layout of the paper including the volume, issue and page numbers.

Link to publication

\footnotetext{
General rights rights.

- You may freely distribute the URL identifying the publication in the public portal. please follow below link for the End User Agreement:

www.umlib.nl/taverne-license

Take down policy

If you believe that this document breaches copyright please contact us at:

repository@maastrichtuniversity.nl

providing details and we will investigate your claim.
}

Copyright and moral rights for the publications made accessible in the public portal are retained by the authors and/or other copyright owners and it is a condition of accessing publications that users recognise and abide by the legal requirements associated with these

- Users may download and print one copy of any publication from the public portal for the purpose of private study or research.

- You may not further distribute the material or use it for any profit-making activity or commercial gain

If the publication is distributed under the terms of Article 25fa of the Dutch Copyright Act, indicated by the "Taverne" license above, 


\section{Community Based Education and Professional Competencies: \\ A study of institutional structures, perspectives and practices in Pakistan}

\section{DISSERTATION}

to obtain the degree of Doctor at the Maastricht University, on the authority of the Rector Magnificus Prof. dr. L.LG. Soete, in accordance with the decision of the Board of Deans, to be defended in public on Friday July 5, 2013 at 16.00 hours.

by

Zahra Ladhani 


\section{Supervisor}

Prof. dr. A.J.J.A. Scherpbier

\section{Co-supervisor}

Dr. F.C.J. Stevens

\section{Assessment Committee}

Prof. Dr. C.P.M. van der Vleuten (Chair)

Dr. J. van Dalen

Prof. Dr. A. de Goeij

Dr. A. van Raak

Prof. Dr. G.J. Wesseling 
The research reported here was carried out at

\section{Maastricht University im Leminum!}

In the School of Health Professions Education

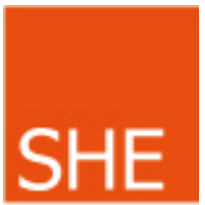

Funded by

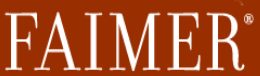


Dedicated to all health workers and teachers of Pakistan 


\section{Table of contents}

Acknowledgements

General Introductions

Competencies for Undergraduate Community Based Education for the Health Professions - A Systematic Review.

Published: Medical Teacher, Sep 2012, Vol. 34, No. 9: 733-743.

Does Community health care require different competencies from physicians and nurses?

Submitted.

Competence, Commitment and Opportunity: Views of faculty on 77 Community Based Education (CBE).

Submitted.

Academic leadership and institutional culture for community based education: an exploration of institutional practices and priorities in Pakistan.

Submitted.

General Discussion 


\section{Acknowledgements}

I would like to acknowledge the guidance and continuous support provided by my supervisors and mentors- Professor Dr. Albert Scherpbier and Dr. Fred Stevens; Ms. Lilian Swaen for her guidance in all administrative matters; Ms. Gorsira Mereke for editing parts of the manuscript; funding support from the International Fellowship in Medical Education (IFME) which was made possible through the Foundation of Advancement in Medical Education and Research (FAIMER) institute and the participants of the studies included in this thesis- the physicians and nurses working in community health care settings; faculty members, deans and administrators of HPE institutes in Pakistan. Last but not least my family, friends and colleagues who were always by my side and believed in me. 
CHAPTER 1

General Introduction 


\section{BACKGROUND}

This thesis concerns Community Based Education (CBE) within the undergraduate medical and nursing programs. The fundamental purpose of establishing a Health Professional's Education (HPE) institute is to achieve three goals: educate health care providers; advance knowledge through research, and provide care to the patients and communities they serve. To achieve these goals, various educational approaches were and are continuously being developed, innovated, experimented and implemented primarily to keep up with the rapidly changing societal health care needs and demands. Reforms ranging from apprenticeship models of training to problem based learning were introduced during the last one and a half century. Recently, two popular innovations of HPE are Community Based Education (CBE) and Competency Approach, the former being introduced few decades back and was popularized in 80s and 90s; the latter is a recent addition in HPE.

A bulk of literature on CBE is devoted to describe what it is ${ }^{[1-5]}$ and to its various models implemented world-wide ${ }^{[6-15]}$. More recently, research has focused on evaluation of these models and knowledge related changes in students attending community based education [16-23]. However, the literature offers little advice on the process of translating the concept of $C B E$ into action, i.e. how to effectively integrate $C B E$ in the larger context of HPE; what pedagogical approaches can successfully engage students in community experiences? What skills and behaviors are required to work effectively in community settings and how to infuse these in HP students so that they graduate with proper orientation to 
local context and health care needs in whatever setting they opt to work? The central theme of this thesis is to examine the integration, or its lack thereof, in HPE institutes, from the perspectives and practices of academic leaders, faculty and graduates. The thesis also explores competency approach with specific skills and roles for CBE in the undergraduate curriculum.

Thus the premise of the thesis revolves around the following basic questions about CBE: Is CBE implemented in its true spirits in HPE institutes? Is the primary purpose of introducing CBE achieved? What are the opportunities and challenges for CBE? Is competency approach a better curricular strategy for $\mathrm{CBE}$ ? If so, what are those competencies? Are the HPE systems (teaching institutes, faculty, and regulatory bodies) ready to take on CBE and its competencies as a core of HPE?

This chapter introduces and describes the terms and concepts underpinning this thesis - Health Professional's Education (HPE), Community Based Education (CBE) and Competency Approach- and where necessary, the concepts are also rationalized along with its brief historical account. The chapter rounds off with summarizing the four research studies conducted under the subject with synopsis of the specific research questions, their relevance and the link between all these studies through which we have attempted to identify current insights and gaps in CBE knowledge and practice. More detailed research questions derived from the central question are addressed in the different chapters of this thesis. 


\section{HEALTH PROFESSIONAL'S EDUCATION (HPE)}

The following few paragraphs briefly describe the term HPE, and our rationale for preferring the term HPE, and for selecting physicians and nurses as a focus for our thesis and the research studies.

The term health professional's education is fairly new, it is about education and preparation of a number of professions concerned with the health care of populations. The other common term found in literature is Medical Education, which is more narrowly focused to the education and practice of medical doctors and practitioners only ${ }^{[24]}$. Health care being an interdisciplinary, nonhierarchical blending of both conventional and complementary care requires a broader team of health professionals, besides there are many other health care providers who practice holistic and relationship based care and do not identify their practice as being medicine-based. Furthermore, the notion of integrative health care includes the goals of treating the whole person, assisting the innate healing properties of each person, promoting health and wellness and the prevention of disease. To achieve this goal, an interdisciplinary team approach is required that is guided by consensus building, mutual respect, and a shared vision on health care ${ }^{[25]}$; thus making HPE an all inclusive term and hence our rationale to prefer the broader term "Health Professions Education" over "Medical Education" for our thesis.

\section{Health Professionals Studied for the Thesis:}

In countries such as Pakistan, only the most conventional health professions -physicians, nurses and dentists - have so far been able to 
attain the professional level i.e. have structured programs for training, are regulated through a professional body, are properly licensed, and go through university education whereas the other health professional education programs are still struggling to attain recognition by both public and policy makers ${ }^{[26,27]}$. Moreover, since the topic of analysis and discourse in this thesis is community based education and competencies of health professionals to address the health care needs at the community (primary and secondary) level, it seemed appropriate to select health professionals who are trained or expected to have training for provision of holistic and comprehensive care at all levels of health care, including community settings. Even though the community related teaching experiences such as didactic sessions, skills, and field visits arefar less than required particularly in a medical curriculum - around 3\%, 250 out of 7,943 for medical and $12 \%, 513$ out of 4,176 contact hours for nursing ${ }^{[28,}$ 29] - yet out of all undergraduate- health professionals' education in Pakistan, only medical and nursing curricula have some elements of structured community teaching. Therefore, the thesis and research studies are focusing on these two groups of health professionals only. With this forward, we will now discuss the central theme of our thesis - Community Based Education in HPE, its definitions, goal, historical background and challenges in its implementation.

\section{COMMUNITY BASED EDUCATION (CBE)}

There is no standard definition of the concept of Community Based Education (CBE); however, various authorities have provided working definitions ${ }^{[1-4]}$ which summarizes that $\mathrm{CBE}$ as a means of implementing 
Community Oriented Medical Education (COME); it is pertinent here to explain COME as the distinction between these terms in not clear to many and is often confused with, or synonymously used with CBE.

COME is defined as "an approach for medical education that focuses on population groups and individual persons taking into account the health needs of the community concerned and it aims to produce community oriented doctors who are able and willing to serve their communities and deal effectively with health problems at primary, secondary and tertiary level i.e. achieving educational relevance to community needs". Community-Based Education, on the other hand, refers to learning activities that take place in a particularsetting, the community setting ${ }^{[2,3]}$; in recent literature, the term $\mathrm{CBE}$ is frequently used as a general term encompassing the concept of COME as well; hence maintaining the given recent context, $\mathrm{CBE}$ is the term used in this thesis also.

\section{Goals of Community Based Education:}

CBE must consist of activities that utilize the community extensively and in a variety of primary and secondary health care settings where not only students but also teachers, members of the community and representatives of other sector are actively engaged throughout the educational process ${ }^{[1-5,30]}$. As Menin elaborates, "it (CBE) provides students with opportunities to become increasingly involved in health issues and, as their competency grows, to plan and provide care. CBE is about engaging in a creative way with communities in the context of real health problems while at the same time learning essential attitudes and skills applicable in both hospital and community settings" ${ }^{\text {[31] }}$. The overall 
goal of CBE is to improve the universal accessibility of basic health care; it aims at training of undergraduate health professional students in the diagnosis, management and, if possible, solution of community health problems. The general objective of CBE programs is to expand students' notion of community health problems through their learning, service and research in the community and thereby to improve the health of the community in which the program is carried out ${ }^{[1-6]}$, in particular to achieve:

- Universal access to and quality of health care including in remote and hard to reach populations.

- Holistic and comprehensive health care comprising of preventive, curative and rehabilitative services.

- Healthy behaviors and lifestyles of individuals and communities at large.

- Team work within the health sector and with other socioeconomic sectors that influence health.

\section{Historical perspective of CBE:}

Before proceeding any further, we will discuss the historical context of CBE to illustrate how the idea was pioneered during last 50 years. In 1978, a meeting of world health leaders was held in Alma Ata, Russia, where Primary Health Care (PHC) was considered as vehicle for improving health of populations and health care for all to be achieved by the year 2000 was set as a target. To ensure achievement of this goal, one of the strategies was to foster the type of educational program for health care providers that could make them responsive to the needs of populations they serve. 
Hence, one year later, a number of medical schools which were already into reforming their curriculum towards community' needs and were trying to be more socially relevant, created a network - Towards Unity for Health (TUFH). In its founding meeting in Kingston, Jamaica, the terms Community Based Medical Education (CBME) and Community Oriented Medical Education (COME) were officiated [32, 34]. Much later, the word "medical" dropped and "Community Based Education (CBE)" remained.

The idea of training of health professionals to ensure care of sick (and healthy) population in their homes and neighborhoods, health promotion, proper sanitation and clean water for disease prevention started to show its current shape roughly a quarter century before the Alma Ata or the Network meetings. For example, as early as 1948, John Ryle emphasized the same notion and suggested that "the training of the doctor, which began with observations on and the care of the sick individual, is due now for a great forward stride. Observations on whole communities, whether great or small (or on appropriate samples), and improved health provisions for them, must henceforward become the prior objective $^{\prime \prime 35]}$. The more structured reflections of CBE were clearly visible in several HPE institutes around the world from early 60 s, and by the time the term CBE was coined there were more than $20 \mathrm{HPE}$ institutes that had already started offering innovative strategies ${ }^{[2,6-8]}$ for various categories of health professionals including physicians (many models), dentists (Australia, Colombia), Midwifes (Thailand), Nurses (Philippines) and allied health workers (Papa New Guinea). These programs either revised their strategic orientation (a) to create community based and health oriented 
instead of disease oriented medical programs (Australia), or (b) made attempts to expand the trainings settings to include community hospital and health centers (Edinburgh, Finland, Thailand,) or (c) made changes in the educational processes and the organizational structures (Maastricht), to extend their relationship with the health services(Mexico City, Philippines) and other sectors (Nepal, Mexico City) and with community partnership (Mexico city, Yugoslavia) or (d) prepared their curricula based on the functions of health providers working in community health center (Australia, Algeria). Each program had at least attempted to introduce one or several modifications to what was later described as $\mathrm{CBE}{ }^{[6-7]}$.

During the time when various models of HPE were coming up, Engel also gave his Bio-Psycho-Social model emphasizing understanding of human behavior, the psychological and social dimensions (personal, emotional, family, community) in addition to the biological aspects (diseases) to be integrated in patient care and education of health professionals ${ }^{[36,37]}$. Despite all these years of investments into reforming health professionals' education to address the holistic health care needs of populations, the aim of universal health care and community oriented health providers is still not achieved and there remains growing concerns about the effectiveness and sustainability of $\mathrm{CBE}^{[16-18,38-44]}$.

\section{CHALLENGES OF TODAY}

Today, the health care scenario is faced by serious challenges such as widening gaps and inequities in health and its access, emerging and remerging communicable diseases in combination with upcoming noncommunicable diseases, increased risks of infectious, environmental, and 
behavioral health problems and poor population at large, particularly of developing nations are still the ones who are suffering the most from these challenges ${ }^{[43,44]}$. And along all this time, the HPE reforms did little good to avert the present health care scenario due to many interrelated problems as Frenk et al. in their recent paper have identified: "fragmented, outdated, and static curricula; mismatch of competencies to patient and population needs; poor teamwork; persistent gender stratification of professional status; narrow technical focus without broader contextual understanding; episodic encounters rather than continuous care; predominant hospital orientation at the expense of primary care; quantitative and qualitative imbalances in the professional labor market; and weak leadership to improve health-system performance $^{\text {[38] }}$.

With the changes in the society and demands for health care, new roles and competences for health professionals have also emerged, forcing HPE institutes to consider adopting further reforms including competency approaches. In the recent past there is an increased proliferation of HPE institutes moving in this direction, albeit there is not much documented experience of utilizing the competency approach for promotion of $\mathrm{CBE}$, in other words, coupling both these approaches. In the next few paragraphs we will describe and provide a brief historical account of competency approach in general education and in HPE.

\section{COMPETENCY APPROACH}

Competency is defined as the blend of skills, abilities, and knowledge needed to perform a specific task. Use of competency as an approach to 
education originated from elementary education and vocational training in the decades of 50s and 60s for training of elementary school in many developed countries, such as New Zealand, Australia, the United States, and the United Kingdom ${ }^{[45-47]}$. Hodge points out that one of the most distinctive characteristics of the competency approach is the emphasis placed on the identification and expression of learning objectives, an emphasis reflected in the 'competency' within the title of the movement ${ }^{[47]}$. He identifies the work of educational theorist Ralph Tyler (1949) who believed that the weakness in the curriculum is the failure to be clear about the purposes of curriculum and portrayed that the prevailing approach to curriculum design which focused on the content of areas of knowledge was not a sufficient basis for structuring a curriculum. Furthermore, Hodge linked the work of Tyler with Bloom, whose taxonomy in 1956 is an important step on the way to adoption of competency approach since it structured the entire field of educational goals into the 'cognitive', 'affective' and 'psychomotor' domains, a construction which is closely related to the contemporary concept of competency as made up of knowledge, attitudes and skills components. Thus, a competency approach in education is aimed at defining, teaching, and assessing competencies. Advocates of competency approach stress on outcome behaviors that can be clearly articulated to students and future employers. It is flexible in shaping learning experiences, and has the ability to match skills development in education with those needed in the work force. This approach has since been espoused for training across other areas, particularly the technical and vocational fields and recently 
into professional disciplines including the health professions to prepare such professional who can practice at a defined level of proficiency, in

accord with local conditions, to meet local needs ${ }^{[48,49]}$.

\section{Competency approach in Health Professions' Education :}

Voorhees noted that professional programs such as health professionals' education have a natural connection with a competency approach because of the clear relationship between student performance and work force expectations ${ }^{[50]}$. Further, learning is facilitated if the way a student learns approximates to the way in which they are expected to carry out later professional tasks. Frenk et al. describe the competency approach as a disciplined way to specify the health problems, identify the requisite competencies required of graduates for health system performance, tailor the curriculum to achieve competencies, and assess achievements and shortfalls ${ }^{[38]}$. Quoting Epstein and Hunder, they stated that: “Competency is the habitual and judicious use of communication, knowledge, technical skills, clinical reasoning, emotions, values, and reflection in daily practice for the benefit of the individual and the community being served" [38]. Since the introduction of a competency approach in HPE, numerous models and categories of competencies have emerged for training of physicians and nurses at undergraduate level (discussed in detail in Chapter 2) which are mainly drawn from hospital settings or focus on preparing health professionals to work in clinical locations. In spite of tertiary focus of competency approach in HPE so far, there is a natural affinity of CBE with the competency approach as it has potential to direct the adaptation of competencies into the curriculum based on specific 
contexts and health care needs. Besides, the competencies that are founded on best practices from the field have higher chances of preparing successful workforce. Likewise, in order to harness students' capabilities for community oriented practice be it in hospital or community setting, it is essential to identify expected and appropriate roles of health professional at all levels including community.

\section{RESEARCH QUESTIONS}

While CBE and competency approach as separate constructs have previously been studied extensively, to examine these two approaches together is central to this thesis which seeks to answer the following research questions:

1. What $\mathrm{CBE}$ related competencies are identified in the literature?

2. Do community settings require different sets of competencies for physicians and registered nurses? What variations exist in the competencies of physicians and registered nurses working in rural, urban and semi urban community settings? What variations exist in the competencies of physicians and registered nurses working in community facilities run by the government, non-governmental organisations (NGOs) or universities?

3. What are perceptions and practices of faculty members' in relation to the implementation of $\mathrm{CBE}$ in their institutions?

4. What are the perspectives of academic leadership about CBE? Do these perspectives promote a culture of community service and CBE? What attributes of HPE institutes' culture support and 
promote CBE? What attributes of HPE institutes' culture will hinder CBE?

\section{THESIS LAYOUT}

The answers to these questions were explored in a variety of studies and settings including HPE institutes and community health centers of a number of cities and small towns of Pakistan, except chapter 2 which explores the concept and application of CBE competencies in the literature. Using a systematic review we searched literature of the past 10 years to find what was already known and published in terms of CBE competencies with specific attention to undergraduate nursing and medical programs. Building on the findings of the systematic review, chapter3 examines the practice of CBE competencies in community settings. Using in-depth interviews and review of job descriptions, it investigates whether the competency themes that we found in the literature are identifiable in the practice of physicians and nurses working in various community settings and, whether these competencies are identifiable and expected by their employers. The next two chapters, 4 and 5 utilize a variety of research methods- focus group discussions, indepth interviews and a web based survey- to explore the practices and perceptions of faculty members concerned with CBE and leadership of HPE institutes in relation to the implementation of $\mathrm{CBE}$ in their institutions.

The last chapter of our thesis assembles and summarizes key findings from all our researches. It also shares strengths and limitations of our studies, discusses its implications for CBE and competencyapproach, and 
in the end, the directions that future research might take are thrashed out and presented.

\section{REFERENCES}

1. Alausa O.K. Bhattacharaya A. Chowdry Z. Duranal. Ermakov V. Manyeneng W.G. et al. Community-based education of health personnel, Nov. 1987; Report no. 746, sponsored by World Health Organization Study Group, Geneva.

2. Hamad B. Community Oriented Medical Education, What it is? Medical Education. (1991) 25: 16-22.

3. Magzoub M.E. Schmidt H.G. A taxonomy of community based medical education. Academic Medicine. 2000; 75 (7), 699-707.

4. Bor D. Position Paper on Community-Based Education for Health Professionals. Education for Health. 2003; 16(3) 400 - 404

5. Hays, R. (2007). Community-oriented medical education. Teaching and Teacher Education, 23, 286-293

6. F. M. Katz and T. Fülöp: editors. Personnel for health care: case studies of education programs. Public health papers 70, Vol 1. Geneva: World Health Organization 1978. http://apps.who.int/iris/bitstream/10665/39452/1/WHO PHP 70

7. F. M. Katz and T. Fülöp: editors. Personnel for health care: case studies of education programs. Public health papers71, Vol 2. Geneva: World Health Organization 1980. http://apps.who.int/iris/bitstream/10665/39452/3/WHO PHP 71

8. Richard R.\&Fulup T. Innovative schools for health personnel: Reports of ten schools belonging to the network of community oriented education institutions for health sciences. 1987; WHO offset publication ISB 9241701021.

9. Ornt D.B. Population Medicine in a Curricular Revision at Case Western Reserve. Acad Med. 2008; 83:327-331.

10. Chamberlain L. \& Lisa J. Integrating Collaborative Population Health Projects into a Medical Student Curriculum at Stanford. Acad Med. 2008; 83:338-344.

11. Finkelstein J. Teaching Population Health as a Basic Science at Harvard Medical School. Acad Med. 2008; 83:332-337 
12. Kerkering K. and Novick,L.F. An Enhancement Strategy for Integration of Population Health into Medical School Education: Employing the Framework Developed by the Healthy People Curriculum Task Force. Acad Med. 2008; 83:345-351.

13. McIntosh S. Training Medical Students in Community Health: A Novel Required Fourth-Year Clerkship at the University of Rochester. Acad Med. 2008; 83:357-364.

14. Talaat W. \& El-Wazir Y. The El-Tal El-Kebir Story: An example of social accountability from Egypt. Medical Teacher. 2012; 34: 1-7

15. HalaasG.W. Instructional Methods and Techniques: The rural physicians associate program: new directions in education for Competency. Education for Health. 2005; 18 ( 3): $379-386$

16. Larry W.C. et al. Perceptions and valuation of a Community-Based Education and Service (COBES) program in Uganda. Medical Teacher. 2011; 33: e9-e15.

17. Kristina T.N. Majoor G.D.Van Der Vleuten. Does Community-Based Education come close to what it should be? A Case Study from the developing world: students' opinions. Education for Health. 2006; 19: $179-188$.

18. Kristina T.N. Majoor G.D. Van Der Vleuten. Does Community-Based Education come close to what it should be? A Case Study from the developing world: evaluating a program in action against objectives on paper. Education for Health. 2005; 189:208.

19. Frances M. O. Yoshimoto C. M. Bell S.\&Nuinos R. Educating health professionals in a community setting: What students' value. Education for Health. 2001; 14(2), 256 -266.

20. Tyler I. V. \& et al. Canadian Medical Students' Perceptions of Public Health Education in the undergraduate Medical Curriculum. Academic Medicine, 2009; 84 (9): 1307 - 13129

21. Umer F. et al. Doctors Perception about Staying In or Leaving Rural Health Facilities in District Abbottabad. Journal of Ayub Medical College, 16(2)

22. Aziz A.Kazi A. Ashraf J.Fatmi Z. Knowledge and skills in community oriented medical education (COME) self-ratings of medical undergraduates in Karachi. The Journal of the Pakistan Medical Association. 2006; 56 (7), 313-317.

23. Alice A.K \& Stuart J. S. Community-based education: is the effort worth it. Medical Education. 2001; 35:315 \pm 316 . 
24. Kreitzer M.J. Kligler B. Meeker W.C. Health professions' education and Integrative health care Commissioned for the IOM Summit on Integrative Medicine and the Health of the Public. February, 2009.

25. Boon, H., V. Verhoef, D. O'Hara, and B. Findlay.From parallel practice to integrative health care: A conceptual framework. BioMed Central Health Services Research 2004; 4:15.

26. Stevens F.C.J. The Sociology of Health Professions. The WileyBlackwell Encyclopedia of Health, Illness, Behavior, and Society. 2014 (forthcoming).

27. Kanji Z.K. Dhamani K. Ladhani Z. Nursing. The Wiley-Blackwell Encyclopedia of Health, Illness, Behavior, and Society. 2014 (forthcoming).

28. Curriculum of MBBS - Revised Edition 2011. Prepared by: Pakistan Medical \& Dental Council (PM\&DC) and Higher Education Commission (HEC), Islamabad; pp 48-52. Accessed on April $17^{\text {th }} 2013$ : http://www.pmdc.org.pk/LinkClick.aspx?fileticket=EKfBIOSDTkE\%3D

29. Curriculum of Nursing education, BScN - Revised Edition 2010. Prepared by: Pakistan Nursing Council (PNC) and Higher Education Commission (HEC), Islamabad

30. Kristina T.N.Majoor G.D. Van der Vleuten C.P.M. Defining generic objectives for community-based education in undergraduate medical programs. Medical Education. 2004; 38 (5), 510-521

31. Menin S. Menin R. Community Based Medical Education. The Clinical Teacher. 2006; 3: 90-96

32. The Network: Towards Unity for Health Official Website. Accessed on March 13th 2013http://www.the-networktufh.org/about.

33. Richards R. Editorial: The Network: TUFH's 25th Anniversary. Education for Health. 2004; 17( 3): $278-279$.

34. Schmidt H.G. Neufeld V. R.Nooman Z. M. Ogunbode T. Network of Community Oriented Education institutions for health sciences. Academic Medicine. 1991; 66(5): 259-263

35. Ryle J. A. Changing disciplines. London: Oxford University Press, 1948. Extracted from quotations in Buck C, Llopis A, Najera E, Terris M. The challenge of epidemiology. Issues and selected readings. Washington; Pan American Health Organization, Regional Office of the WHO, 1989. 
36. Engel GL. The need for a new medical model: a challenge for biomedicine. Science. 1977;196:129-36.

37. Smith R.C. The Biopsychosocial Revolution: Interviewing and Provider-patient Relationships Becoming Key Issues for Primary CareJ Gen Intern Med. 2002 April; 17(4): 309310.doi: 10.1046/j.1525-1497.2002.20210.

38. Frenk J. Chen L. Bhutta Z.A. et al. Health professionals for a new century: transforming education to strengthen health systems in an interdependent world. www.thelancet.com. 2010 November 29; doi:10.1016/S0140-6736(10)61854-5

39. Bloom S.W. Structure and Ideology in Medical Education: An analysis of resistance to change. Journal of Health and Social Behaviour. 1988; 29: 294-306.

40. AhemdJ. \&Shiakh B.T. The state of affairs of Primary health care facilities' in Pakistan. Where is the state' stewardship? EMHJ. 2011; 17(7): 619-623.

41. Asad K. Failure analysis of Primary health Care in Pakistan and recommendations for change. Health Commission report, Insaf Research Wing. June 2009.

42. Lubna B. A, Akram, D.S, Ali S.K. Development of the CommunityOriented Medical Education Curriculum of Pakistan: A Case Report on the national initiative on curriculum development. Education for Health. 2006; 19: $223-228$

43. Boelen $\mathrm{C}$. The challenge of changing medical education and Medical Practice. World Health Forum. 1993; Vol 14: 214- 216.

44. Bryant J.H. Educating Tomorrow's Doctors. World Health Forum. 1993; 14: 216- 230.

45. Department of Education. Working together: education and training. London: HMSO, 1986.

46. Grant G. On competence: a critical analysis of competence- based reforms in higher education. San Francisco: Jossey - Bass, 1975.

47. Hodge $S$. The origins of competency-based training. Australian Journal of Adult Learning. 2007: 47, 2. 180-209. Accessed on March $12^{\text {th }}$ 2013. http://www.eric.ed.gov/PDFS/EJ797578.pdf

48. Foss \& et al. Using Professional Specialty Competencies to Guide Course Development. Journal of Nursing Education. 2004; 43 (8), 368-375. 
49. Anna A. \& Made M. Outcomes based education: Where has it come from and where is it going. Issues in Educational Research, 2007: 17(2), 161-182Tanner C.A. Competency-based education: The new panacea? Journal of Nursing Education. 2001; 40, 387-388.

50. Voorhees, R.A. Competency-based leaning models: A necessary future. In R.A. Voorhees (Ed.), Measuring what matters: Competencybased leaning models in higher education 2001; pp. 5- 13. San Francisco: Jossey-Bass. 


\section{Chapter 2}

\section{Competencies for Undergraduate Community Based Education for the Health Professions - A Systematic Review}

Published:

Zahra Ladhani, Albert J.J.A. Scherpbier, Fred C.J. Stevens.

Medical Teacher Sep 2012, Vol. 34, No. 9: 733-743. 


\section{ABSTRACT}

\section{Background}

Community Based Education (CBE) along with competency approach is increasingly becoming popular. However, there appears to be lack of evidence on $\mathrm{CBE}$ competencies for undergraduate curriculum therefore this systematic review attempted to identify and categorized CBE competencies to determine frequently used.

\section{Aims}

The systematic review was aimed at identifying and categorizing CBE competencies implemented in nursing and medical schools to inform all stakeholders of health professional' education.

\section{Method}

A systematic review of electronic data bases including MEDLINE, CINAHL \& ERIC and manual search of four medical education journals was carried out. Search was restricted to original research, published in English language between January 2000 and December 2009.

\section{Results}

Nineteen studies fulfilled the search criteria, the competencies identified were categorized under six themes: Public health; Cultural Competence; Leadership \& Management; Community Development; Research and Generic Competencies. Moreover, a number of clinical competencies also found to be overlapping with CBE.

\section{Conclusions}

The literature on CBE competencies is limited in numbers and in its geographical span as most of the studies found was from developed countries; to expand the efforts to other institutions and countries core competencies for CBE must be recognized and disseminated widely for its integration in health professionals' curriculum. 


\section{BACKGROUND}

One of the strategies recommended by the World Health Organization (WHO) for achieving "Health for All" is reforming health professional curricula by incorporating concepts and methods to prepare students for providing care at all levels of health care settings and by aligning education with community needs ${ }^{1}$. On similar lines, the Pew Health Professions Commission recommended that health professionals' roles and obligations should be expanded to include "community" as an integral part of their professional responsibility ${ }^{2,3}$. These notions gave rise to Community Oriented Medical Education (COME) and, later, to the introduction of "Community-Based Education (CBE)" in health professional education ${ }^{4}$.As the $C B E$ movement gained momentum, medical educators across the globe introduced various models for teaching community health concepts and promoting students' understanding of social accountability which are well documented as well.

Alongside $\mathrm{CBE}$, there is also the rise of competency-based education; the National Council of Nursing in the USA defined competence as "the application of knowledge and the interpersonal, decision-making and psychomotor skills expected for the practice role, within the context of public health, safety and welfare" ${ }^{5}$. In Canada, the National Working Group on Continuing Competence for Registered Nurses developed a similar definition: "The ability of a Registered Nurse to integrate and applythe knowledge, skills, judgment, and interpersonal attributes required to practice safely and ethically in a designated role and setting ${ }^{\prime 6}$; a definition that acknowledges that the practice environment has a direct 
bearing on competence, including knowledge. Jones ${ }^{7}$ also noted that professional education programmes, such as those in health professional education, have a natural connection with competency-based education, because of the direct relationship between student performance and work force expectations. The goal of competency based education is to ensure that curricula are based on scientific evidence and equip students with standardized, measurable competencies as evidence of their preparedness for practice. Furthermore, the competencies that are developed based on best practices identified at the field level have higher chances of preparing successful workforce. Likewise, in order to harness students' capabilities for wider public health practice, it is essential to identify expected and appropriate roles of health professional at community level.

The competency approach for health professional education currently focuses on preparing them to treat diseases and care for sick at secondary and tertiary level care. Prominent examples of competency based approach for physicians include Tomorrow's Doctors published by the General Medical Council (GMC), six general competencies ${ }^{8}$ by the Graduate Medical Education (ACGME -Patient Care; Medical Knowledge; Practice-based Learning and Improvement; Interpersonal and Communication Skills; Professionalism and Systems-based Practice) of the US' Accreditation Council, nine abilities for future physicians by Brown University", and the CanMEDS ("meta-competencies" or physician roles: Medical Expert, Communicator, Collaborator, Manager, Health Advocate, Scholar \& Professional) framework comprising seven roles for the 
physician $^{10}$ by the Royal College of Physicians and Surgeons of Canada. For nursing graduates, the United States Council of State Boards of Nursing $^{5}$ and the Canada National Working Group on Continuing Competence for Registered Nurses ${ }^{6}$ are main examples. Along with clinical skills, these competency models have identified a number of generic competencies (communication, problem solving, critical thinking and decision making) however little attention is paid to the competencies required for preventing illness and promoting health through primary care or community based setting. Tyler ${ }^{11}$ reports that medical students perceive their public health curriculum negatively due to problems relating to the structure, content and delivery of the curriculum, which fails to provide them with a clear understanding of their role in communities. Kristina et al. ${ }^{16}$ also observed that "although CBE has been widely accepted as important innovation in undergraduate medical education, little attention has been given to a rational definition of objectives for CBE program."

\section{AIMS}

CBE-related competencies found in the literature are mainly developed by international organizations such as WHO (Five-Star Doctor) ${ }^{12}$, The Association of Community Health Nursing Educators (ACHNE) and Quad Council Public Health Nursing Organizations ${ }^{13}$ which are adopted and customized by institutions offering various levels of health profession' education such as post graduate or graduate levels. In the medical education literature, however, there appears to be lack of evidence addressing adoption of CBE competencies for undergraduate curriculum 
nor any systematic or formal evaluations of such curricula which have incorporated CBE competencies were found. We therefore conducted a systematic review aimed at identifying and categorizing $\mathrm{CBE}$ competencies implemented in nursing and medical schools and documented in peer reviewed journals. Keeping in view the interdisciplinary nature of $\mathrm{CBE}$ and overlap in the roles of health professionals particularly in remote areas of resource poor countries, it was considered important to identify competencies for at the least two health professionals- physicians and nurses.

\section{METHODS}

We searched the literature for articles on CBE core competencies in undergraduate nursing and medicine curricula. We were interested in articles that described an explicit relationship between "competency" and curricular approach, were reviews or used qualitative or mixed methods, were published in English between January 2000 and December 2009 and included an abstract. We excluded studies in which competency was only implied and referred to by terms like outcome, studies conducted in postgraduate education, opinion papers, descriptive papers, editorials, commentaries and articles on competencies in on-line education.

\section{Search strategy:}

We searched the MEDLINE, CINAHL and ERIC databases for papers published between January 2000 and December 2009, and we manually searched issues of Academic Medicine, Education for Health, Medical Education and Medical Teacher published during the same period by 
browsing the tables of contents and reviewing abstracts in cases of doubt regarding inclusion.

\section{Screening of articles and selection criteria:}

In selecting papers for inclusion in the review, we adhered to the guidelines of Best Evidence Medical Education (BEME) ${ }^{14}$ starting with an initial search in which we reviewed titles only. This resulted in 511 articles, from which we eliminated duplications and articles not meeting the inclusion criteria, leaving 77 articles for second level screening, in which the first author assessed the full text of the articles, and abstracts of the articles were shared among the co-authors for assessment. Since most of the resulting eleven articles dealt with competencies or content related to socio-cultural aspects, we expanded the search by adding the keyword "cultural competencies". This additional search increased the number of papers included in the review to nineteen (Fig. 1).

\section{RESULTS}

The following information was abstracted from the final articles $(N=19)$ : name and location of the institution, the academic programme involved, academic year in which the competencies are introduced/taught, the method used for arriving at the list of competencies and a list of the competencies involved. 
Fig. 1: Graphical representation of the search

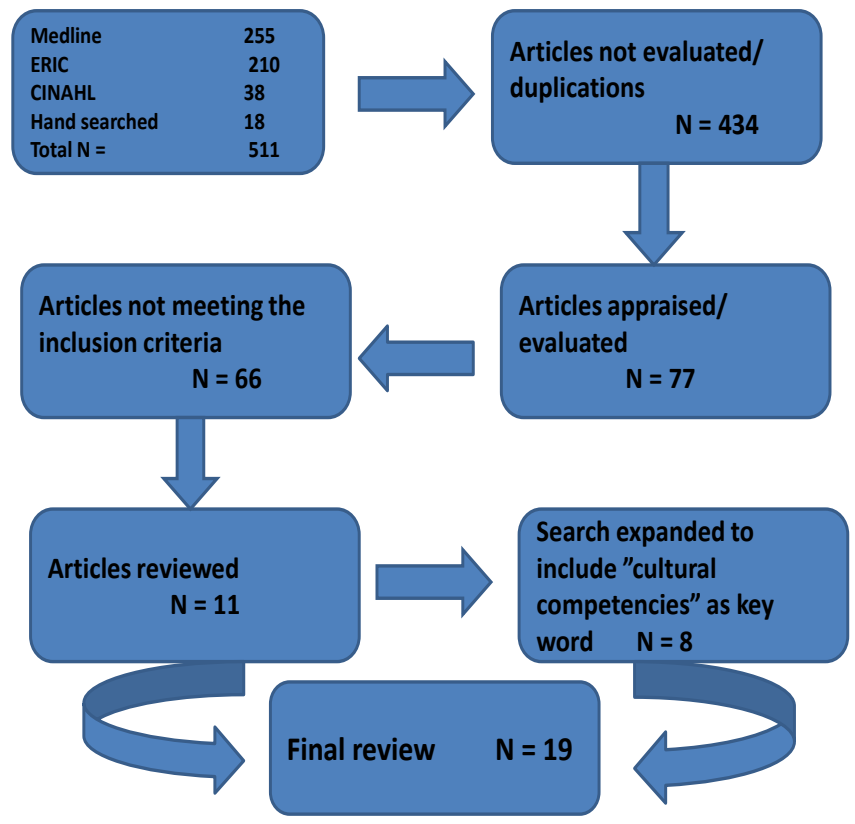

Of the nineteen articles selected for review, thirteen were concerned with medical programmes, four with nursing programmes and two with programmes relating to multiple health professions, such as medicine, nursing, dental and allied health professions. Thirteen articles originated from the USA, two from the Netherlands and one each from New Zealand, South Africa, the United Arab Emirates and the UK. Most articles reported that competencies were derived from the existing competency models $(\mathrm{N}=7)^{15-21}$. Six articles have described in detail their process of curriculum review ${ }^{22-27}$. Five articles ${ }^{28-31}$ do not explicitly state their method, and one used Delphi rounds ${ }^{32}$. 
The length and place of CBE courses in the curriculum vary. Barss et al. ${ }^{22}$ describes the introduction of competencies in first year only, Michener ${ }^{33}$ describe full integration of $\mathrm{CBE}$ in the curriculum and Strasser et al. ${ }^{32}$ propose additional year focused on CBE to a regular nursing degree programme; the summary is provided in Table 1.

We grouped the competencies described in the nineteen articles into the following themes:

1. Public health

2. Cultural Competence

3. Leadership and management

4. Community development and advocacy

5. Research and evidence based practice

6. Generic Competence: communication, problem solving, decision making, creativity, motivation, self- reflection, facilitation and presentation.

We will discuss these themes consecutively. 
Table 1: Summary of the articles included in final review

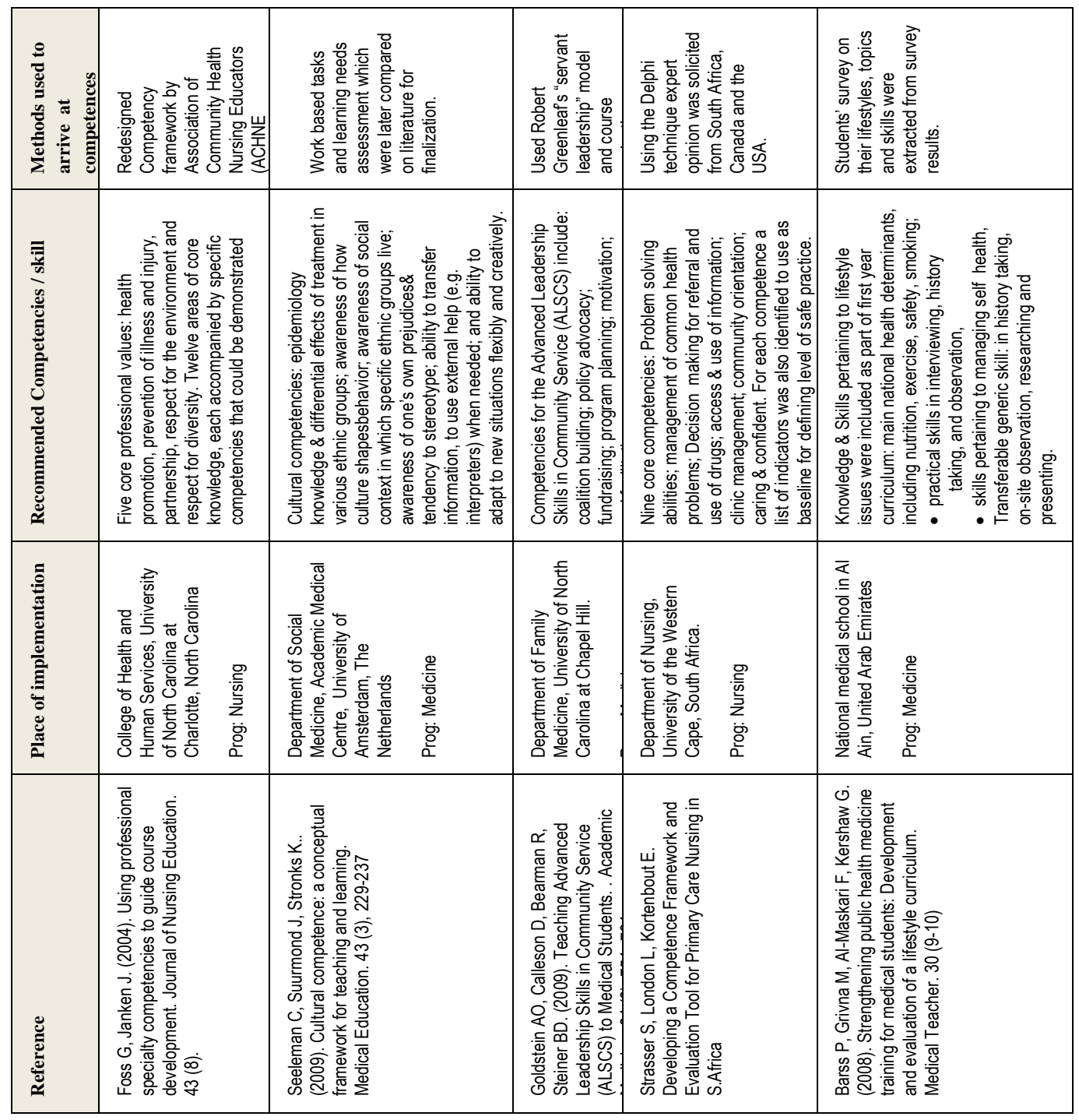




\begin{tabular}{|c|c|c|c|c|}
\hline 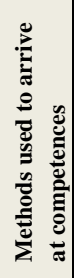 & 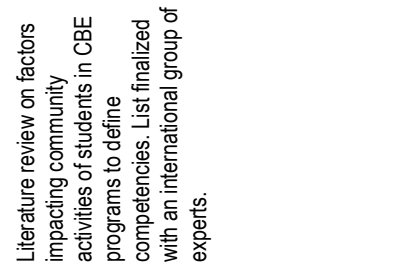 & 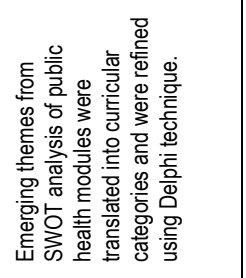 & 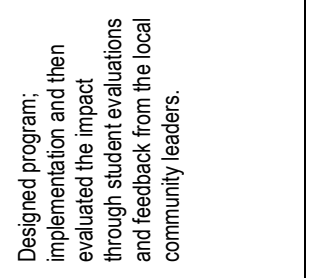 & 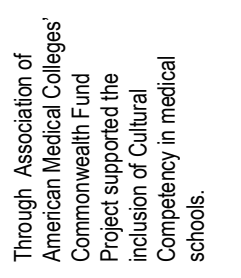 \\
\hline 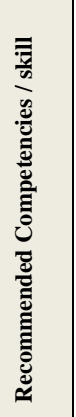 & 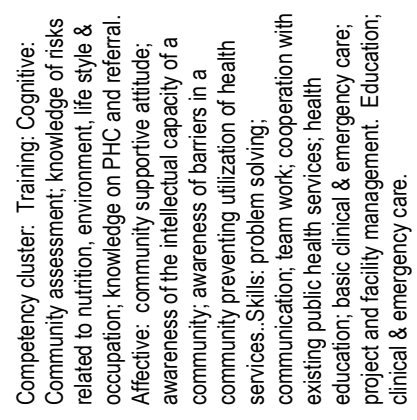 & 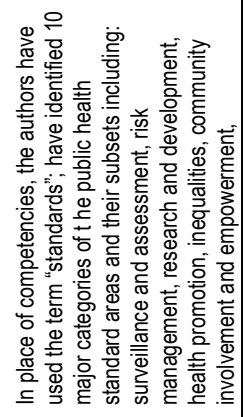 & 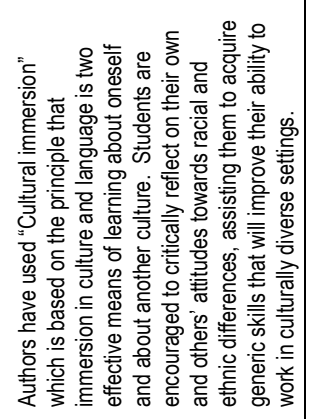 & 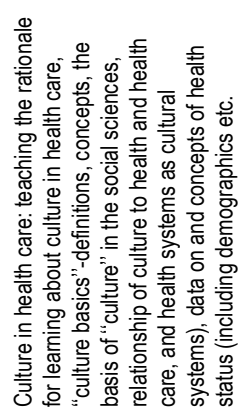 \\
\hline 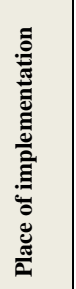 & 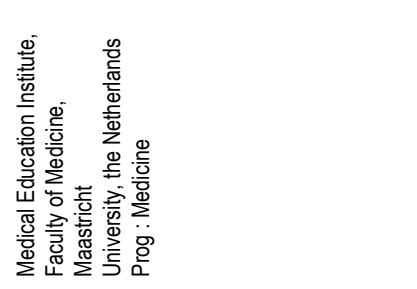 & 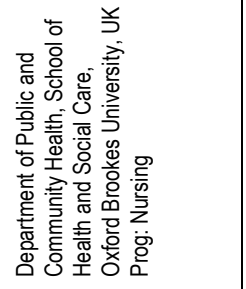 & 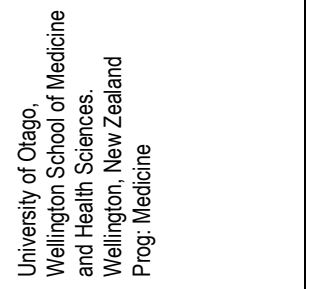 & 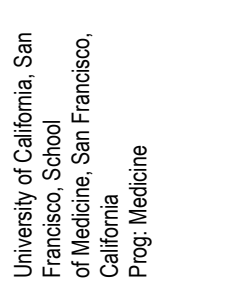 \\
\hline 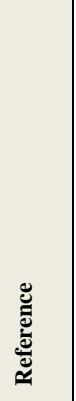 & 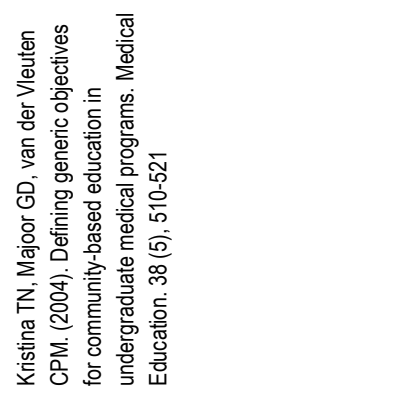 & 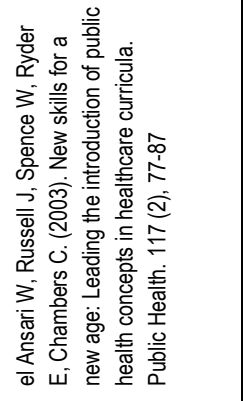 & 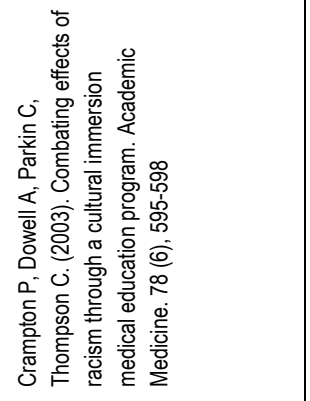 & 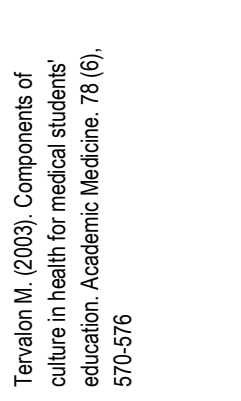 \\
\hline
\end{tabular}




\begin{tabular}{|c|c|c|c|c|}
\hline 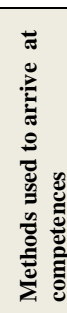 & 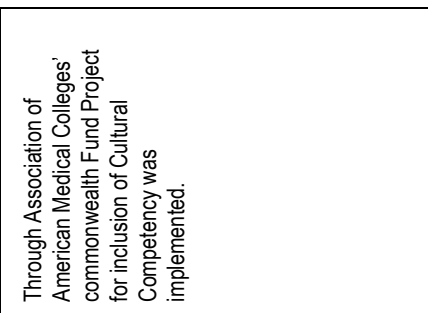 & 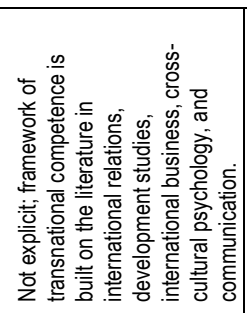 & 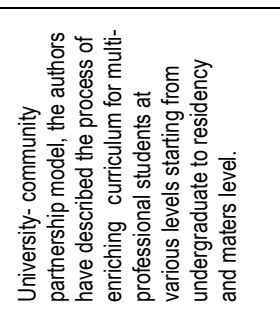 & 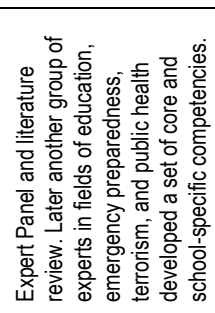 \\
\hline 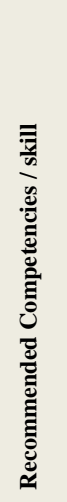 & 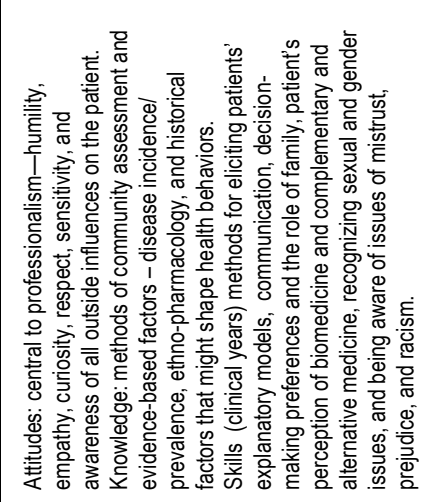 & 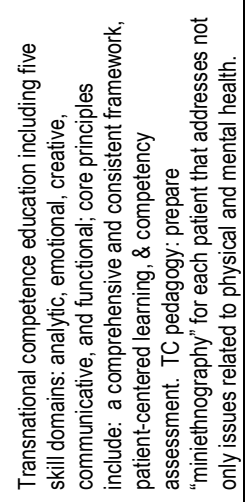 & 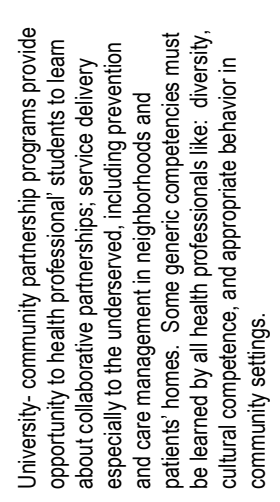 & 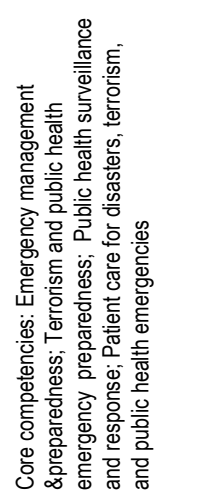 \\
\hline 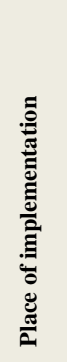 & 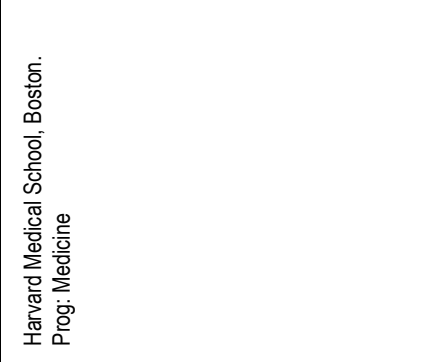 & 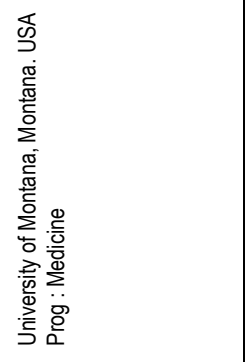 & 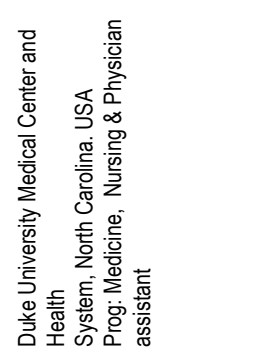 & 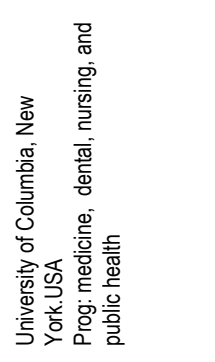 \\
\hline 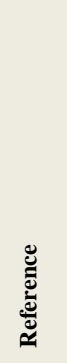 & 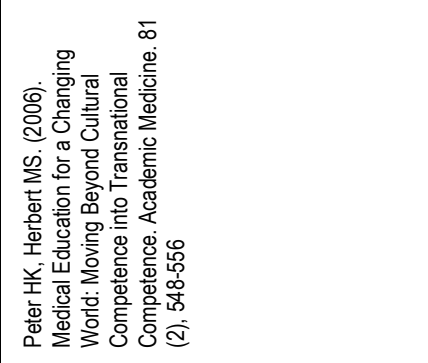 & 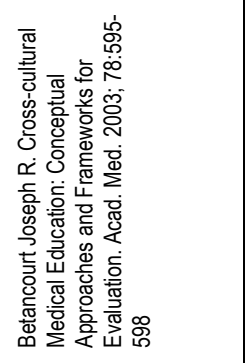 & 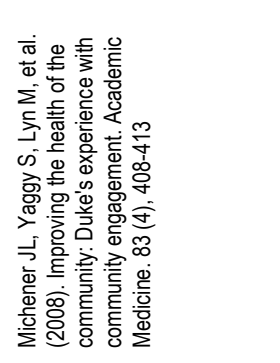 & 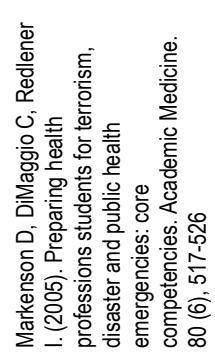 \\
\hline
\end{tabular}




\begin{tabular}{|c|c|c|c|c|c|}
\hline 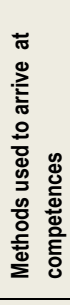 & 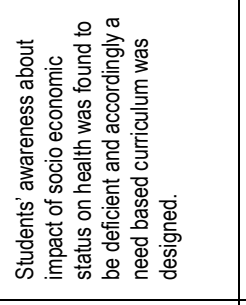 & 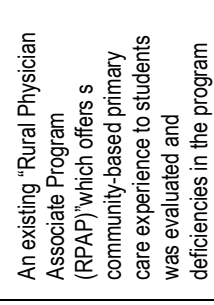 & 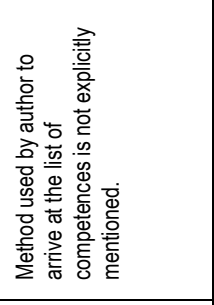 & 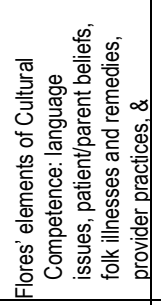 & 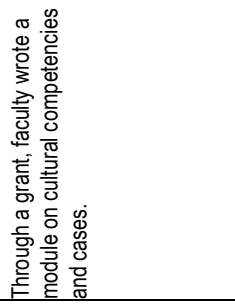 \\
\hline 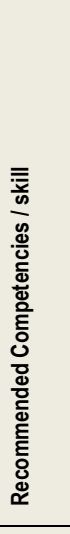 & 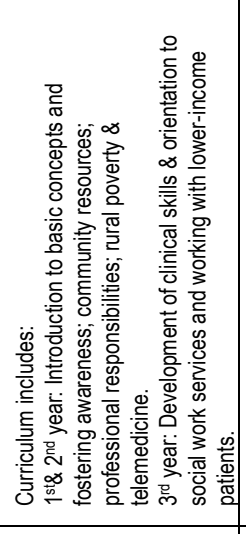 & 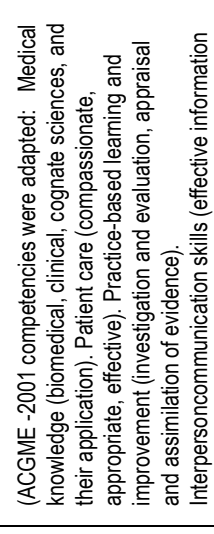 & 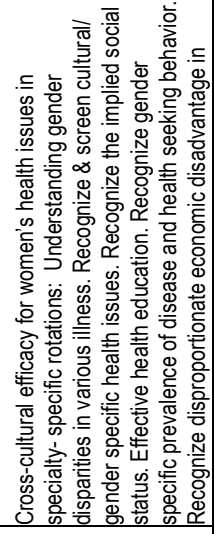 & 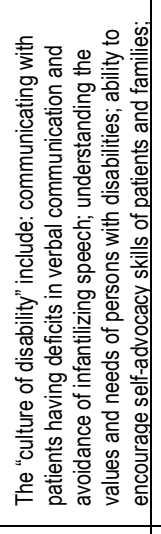 & 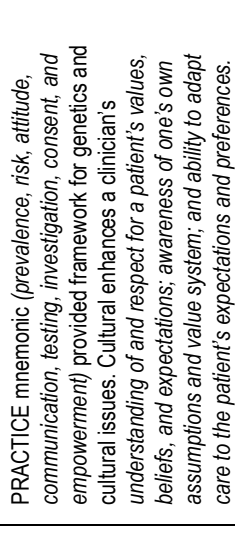 \\
\hline 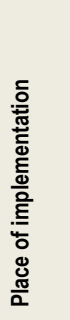 & 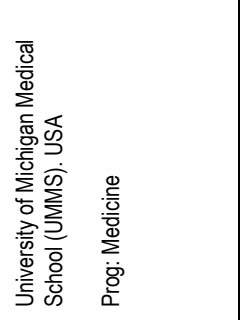 & 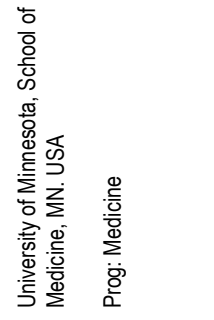 & 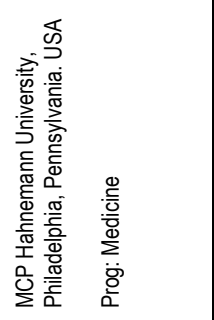 & 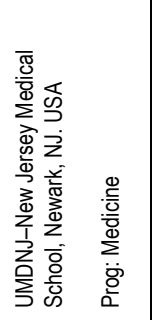 & 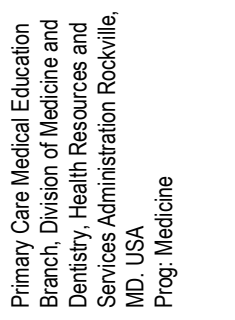 \\
\hline 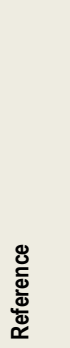 & 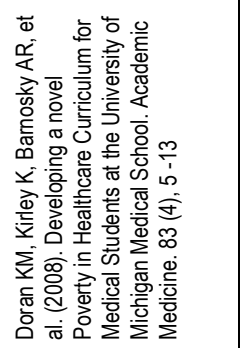 & 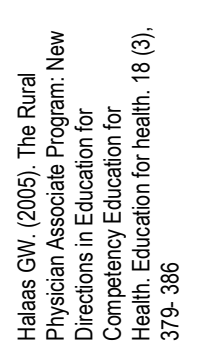 & 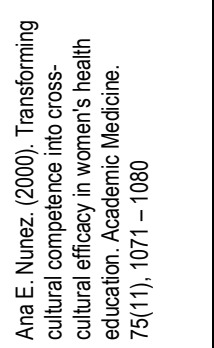 & 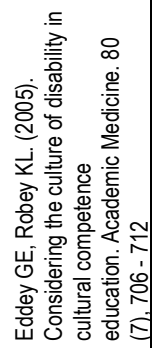 & 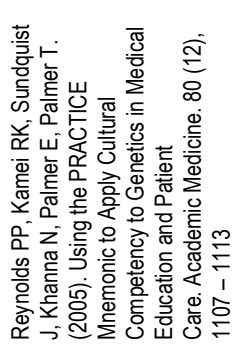 \\
\hline
\end{tabular}




\section{Public health:}

Competencies under this theme emerged as "core" competencies for CBE. Specific skills pertaining to this theme are epidemiological and biostatics skills $^{15,16,23}$, such as prevention of illness and injury, health promotion, surveillance and risk assessment and management. Public Health is considered as important competency for both- medicine and nursing students, Barss ${ }^{22}$ quoting from 'Tomorrow's Doctors' 3, 10 has reported inclusion of these competencies for medical students. Similarly, Strasser ${ }^{32}$ and Foss et al. ${ }^{15}$ suggest integrating public health skills namely community assessment and interventions, family nursing, health screening and health education in nursing curriculum in order to prepare nurses for provision of comprehensive primary health. Markenson ${ }^{25}$, in addition to general public health competencies, recommends preparing all health professions students i.e. of medicine, dentistry, nursing and public health for responding to terrorism, disasters and public health emergencies.

\section{Cultural Competence:}

With the emergence of multicultural societies as a result of rapid movement of people between countries, health professionals are increasingly required to provide appropriate care to people from different ethnic backgrounds. Hence, in the literature, and in the CBE literature in particular, 'cultural competence' is gaining importance in various countries, especially those with high immigration rates like Canada and the USA. Acquiring cultural competence are considered equally important for all health professionals, skills comprising the application of knowledge of social and cultural factors that affect health care practice, the use of 
relevant data sources and best evidence in providing culturally competent care, the promotion of safe and quality outcomes of care for diverse populations, advocating for social justice and elimination of health disparities and continuous cultural competence development are identified by Calvillo et al. ${ }^{21}$. In addition, 'Cultural immersion' is identified by Crampton et al. ${ }^{24}$ as an important skill that aims at encouraging students to critically reflect on their own and others' attitudes towards racial and ethnic differences. Seeleman et al. ${ }^{17}$ recommends knowledge of epidemiology and the differential effects of treatment in diverse ethnic groups, awareness of how culture shapes individual behaviour and thinking, awareness of the social context in which specific ethnic groups live, awareness of one's own prejudices and tendency to stereotype, ability to transfer information in a way the patient can understand and to use external help (e.g. interpreters) when needed and the ability to adapt to new situations flexibly and creatively.

Three articles take account of the possibility that cultural factors may contribute to health disparities, based on the notion that there are certain vulnerable groups within societies who often receive inadequate health care compared to majority populations for example women of colour and people with physical or mental disabilities acknowledging the core values of disability culture including emphasis on interdependence rather than independence $^{20,27,31}$.

\section{Leadership and management:}

In response to the recommendation by the Institute of Medicine that "increased physician leadership and opportunities for leadership training 
would help redesign the health care system for the 21st century", Goldstein et al. ${ }^{18}$ implemented 'The Advanced Leadership Skills in Community Service (ALSCS) elective' to increase medical students' leadership skills, with emphasis on community service. This programme includes coalition building, policy advocacy, fund-raising, programme planning, motivation and facilitation as specific leadership competencies. El Ansari et al. ${ }^{23}$ identifies strategic leadership as one of ten public health standards, with a related subset including developing, sustaining and implementing a vision and objectives for health. Similarly, Strasser ${ }^{32}$ identifies leadership and management as essential competencies for nurses working in primary care settings who are required to provide the full spectrum of services including managing health care centres and services at household level ${ }^{15,32}$. Skills such as independently managing health centres as well as patients with common conditions (from a list of health conditions identified by the South African Nursing Council), knowing when and where to refer, being confident in accessing and using information.

\section{Community development and advocacy:}

Foss et al. ${ }^{15}$, Tervalon ${ }^{28}$ and Michener et al ${ }^{33}$ have identified community partnerships, goal setting, designing interventions, and identification of appropriate participants for community project as important competencies. Michener et al. $^{33}$ illustrate their university-community partnership programmes as essential for students' learning about collaborative partnerships and service delivery, especially to the underserved neighbourhoods and patients. Tervalon ${ }^{28}$ suggests 
community participation as one of the core competencies including the use of expert teachers, community-school partnerships and the community as a learning environment.

Specific competencies pertaining to this theme for nursing graduates include advocating for community health, influencing health-related legislation at the local, state and national levels, interpreting the effects of the economic and political environments and population growth on global health and using ethical problem-solving strategies to address ethical problems (at the community level) ${ }^{15}$. In their description of the ALSCS curriculum, Goldstein ${ }^{18}$ suggests that medical students must be able to select specific advocacy tools to meet a policy objective and influence legislation (to lobby policy makers, to counter opposing lobbying activities, to draft legislation) and to mobilize community resources to effect policy change.

\section{Research and evidence based practice:}

This theme comprises competencies like appraising, planning and managing research and implementing best evidence in health care practice. Kristina et al. ${ }^{16}$ and El Ansari et al. ${ }^{23}$ emphasize that CBE should include various dimensions of research specifically "investigation skills from assessment of populations health care needs to evaluation of the effectiveness of various models of care delivery, capitalizing on principles of epidemiologic transition. Healthcare professionals should also be able to carry out health policy analysis and healthcare planning for service provision as well as identification of areas of resource need, based on best available evidence and/or best practices. Barss et al. ${ }^{22}$ includes, in their 
curriculum, skills in research, writing and presentation pertaining to life style. Calvillo et al. ${ }^{21}$ includes among the cultural competencies for nursing graduates the use of relevant data sources and best evidence as a basis for providing care. Moreover, nurses must be cognizant of sources of evidence and be able to critically appraise evidence to design culturally appropriate care, have an understanding of ethical guidelines for conducting research and be able to conduct and critique research with diverse populations.

Generic competence (communication, problem solving, decision making, creativity, motivation, self- reflection, facilitation and presentation):

The competencies grouped under this theme are referred to as "generic", because these are required in all settings and at all levels of care and not limited to CBE or primary care settings only. Most of the articles see generic skills as overarching competencies, which are presented either as a group or individually. In most articles it is implied that these skills communication, problem solving and decision making, in particular - are core components of undergraduate curricula.

Kristina et al. ${ }^{16}$ carried out an extensive literature review and had a panel of experts review their work on defining CBE objectives, which concluded that one of the major categories of skills in the curriculum should include problem solving, communication, team work, cooperation with existing public health services, health education, basic clinical and emergency care and project and facility management. Barss et al. ${ }^{22}$ group together assessment, interviewing and observation as "practical skills". Goldstein ${ }^{18}$ 
includes motivation and facilitation (of underserved populations), institutionalizing change and effective presentation skills as part of leadership development for medical students.

The articles that focus on cultural diversity strongly promote selfreflection skills. Tervalon ${ }^{28}$ says that "learning to use self-assessment and self-reflective processes and tools can set a standard for students that can assist them throughout their professional lives to interface in each clinical encounter with humility, compassion, and confidence". Ana ${ }^{31}$ includes self reflection among the assessment methodologies stating that this is “essential for the assessment of students' progress and for professional development".

\section{Overlapping nature of competencies}

Some of the competencies identified in the articles can be categorized under multiple themes. Seeleman et al. ${ }^{17}$ for example proposes, under the cultural competence integration of epidemiology and generic skills.

Similarly, Goldstein et al. ${ }^{18}$ integrates the theme of community development with leadership and management. Figure 2 illustrates how CBE competencies overlap.

One of the important findings is that CBE competencies interrelate and overlap not only with each other but also with clinical competencies, and should therefore be taught in relation to and within the context of other subjects of the undergraduate curriculum. For example, while explaining the role of nurses within primary care, Strasser ${ }^{32}$ contends that providing curative services at a primary care level requires strong history-taking, diagnostic as well as management skills. She further elaborates that the 
health assessment, treatment and care is seen as the gold standard for attaining competence in primary care and that the competencies identified are not limited to one subject and cannot be taught in isolation, but should spread across various subjects as it is difficult to tease CBE competencies apart from other competencies, especially the generic ones. Foss ${ }^{15}$, Kristina $^{16}$, Barss ${ }^{22}$, El Ansari ${ }^{23}$, and Markenson, ${ }^{25}$ all have mapped the curriculum of their respective institutions and found that many topics and competencies for CBE are already part of the traditional curriculum.

\section{Figure 2: Interrelation and overlapping of competencies}

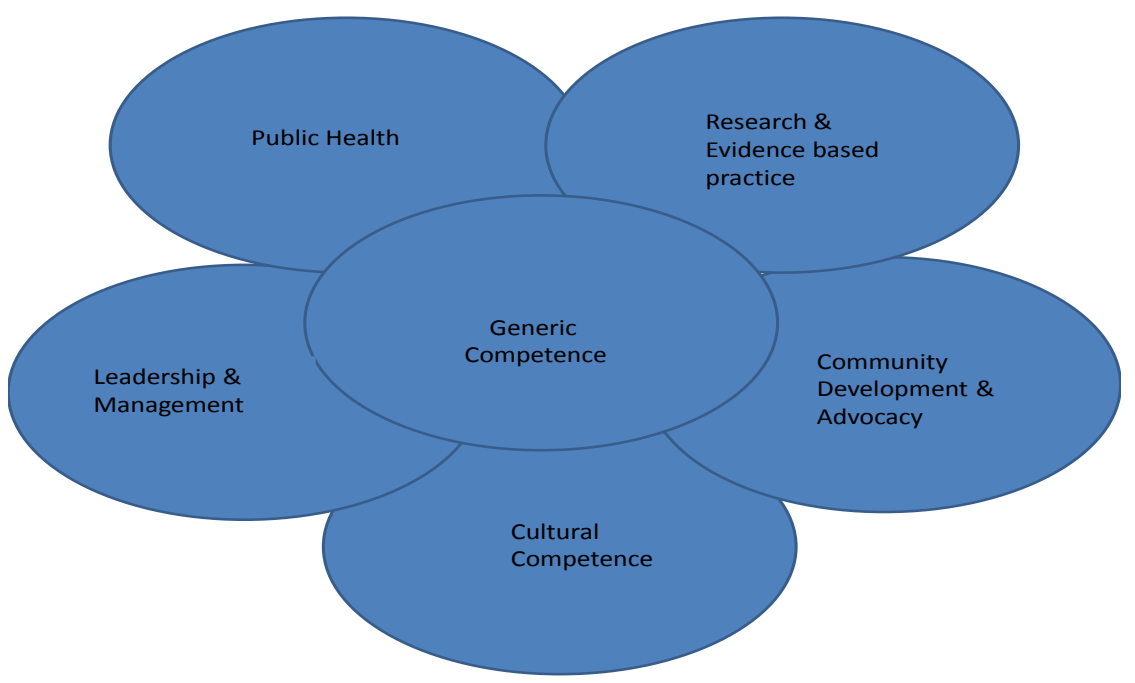




\section{DISSCUSSION}

The CBE literature is mostly concerned with describing teaching models, curricula or cases of effective CBE, while only few articles have identified sets of competencies for undergraduate medical and nursing programmes. The lack of coverage of specific CBE competencies may be due to the fact that $\mathrm{CBE}$ either uses traditional teaching approaches or does not have a specific set of competencies. Our results highlight similar shortcomings in the recent literature, the studies were not only limited in number but also in countries of origin, with most studies being conducted in developed countries. This suggests that innovations in CBE are confined to a few well resourced countries and are either not adopted or not documented in those parts of world where CBE competencies are most needed, i.e. poor resourced countries where access to competent health providers is one of the major obstacles to effective health care. This review has identified a number of CBE competencies, some of which are generic or common to all subjects while there are also a number of competencies specific to CBE only.

Each teaching institution has unique curricular needs depending on national as well as local circumstances, which are vital in planning a competency-based curriculum; however for undergraduate level CBE programmes competencies like public health, community development and leadership should be the minimum requirements. Incorporating these competencies into curricula will demand innovative strategies for teaching and assessment, such as moving learning activities into field sites or community settings to help students understand and appreciate the 
interplay between geopolitical and economic determinants and health outcomes.

The CBE competencies, such as generic, cultural and research are not unique to $\mathrm{CBE}$ and do not necessarily, require community based settings. These are generally considered important life skills for all professionals, and for health professional students these competencies could easily be integrated with other clinical experiences in hospitals or outpatient settings, where students can practice these while they work with patients and their families. Institutions for health professional education offering a competency based undergraduate curriculum that does not include CBE also teach competencies like "effective communication" and "problem solving", which are listed as important competencies by all proponents of competency-based education. These skills are also considered vital for a wide range of hospital-based activities, such as patient care, consultation and collaboration with colleagues and co-workers, and teaching and/or presentation skills in the medical arena. These skills can be incorporated in traditional curricula without major revisions or resources. Initiating the teaching of $\mathrm{CBE}$ competencies by building on available resources will certainly help jump start competency based CBE curriculum.

Future research is required on how these competencies are taught and assessed within interdisciplinary curricula; how these are perceived by faculty members, students and communities and ultimately if they have any bearing on improving the health status of the populations served by graduates from competency based CBE programmes. 


\section{CONCLUSIONS}

Since the review is limited to peer-reviewed studies published between 2000 and 2010, it cannot be excluded that relevant studies have been overlooked. Furthermore, the exclusion of grey literature and articles written in other languages than English may have introduced publication bias. However, given that we combined electronic and manual searches, it seems safe to assume that the search was sufficiently comprehensive and helps us conclude that the literature on CBE competencies is limited and to expand the efforts to other institutions and countries core competencies for CBE must be recognized and disseminated widely for its integration in health professionals' curriculum.

\section{REFERENCES}

1. Alausa OK, Bhattacharaya A, Chowdry Z, Durana I, Ermakov V, Manyeneng WG, et al. 1987, Community-based education of health personnel, Nov. Report no. 746, sponsored by World Health Organization Study Group, Geneva

2. Kinder G, Cashman SB, Seifer SD, Inouye A, Hagopian A. (2000). Integrating Healthy Communities Concepts into Health Professions Training. Public Health Reports. 115 (2-3), 266 -270.

3. O'Neil EH, Seifer SD 1995, Service-Learning in Health Professions Education: Bibliography, Pew Health Professions Commission, San Francisco CA.

4. Richard R, Fulup T 1987, Innovative schools for health personnel: Reports of ten schools belonging to the network of community oriented education institutions for health sciences. WHO offset publication, ISB 9241701021.

5. National Council of State Boards of Nursing. (1996). NCSBN Position Paper. Available: 
https://www.ncsbn.org/Continued_Comp_Paper_TestingServices. pdf. Last accessed 2010 Jan 5.

6. Campbell B, Mackay G. (2001). Continuing Competence: An Ontario Nursing Regulatory Program That Supports Nurses and Employers. Nursing Administration Quarterly. 25 (2), 22-30.

7. Jones EA. (2005). Working in partnership with faculty to transform undergraduate curricula. In: Voorhees RA Measuring what matters: Competency-based leaning models in higher education. San Francisco, CA : Jossey Bass Inc. 15-27.

8. Lurie S J, Mooney CJ, Lyness JM, MD. (2009). Measurement of the General Competencies of the Accreditation Council for Graduate Medical Education: A Systematic Review. Academic Medicine. 84 (3), 301-309.

9. Brown Medical School 2000, An Educational Blueprint for the Brown Medical School, 45p, Office of Curriculum Affairs, USA

10. Frank J R (2005). The CanMEDS 2005 Physician Competency Framework. 2nd ed. Ottawa: The Office of Education, Royal College of Physicians and Surgeons of Canada

11. Tyler IV, Hau M, Buxton JA, Elliott L, Harvey. BJ, Hockin JC, Mowat DL. (2009). Canadian medical students' perceptions of public health education in the undergraduate medical curriculum. Academic Medicine. 84 (9), 1307-1312

12. World Health Organization 1996, Doctors for Health, A WHO Global Strategy for Changing Medical Education and Medical Practice for Health for All, Geneva.

13. Quad Council. Quad Council Public Health Nursing Competencies; 2003, 11p.

Alex Haig, Marshall Dozier. (2003). BEME Guide No 3: Systematic searching for evidence in medical education -Part 1: Sources of information. Medical Teacher. 25 (4), 352 -363.

14. Foss $G$, Janken J. (2004). Using professional specialty competencies to guide course development. Journal of Nursing Education. 43 (8).

15. Kristina TN, Majoor GD, van der Vleuten CPM. (2004). Defining generic objectives for community-based education in undergraduate medical programmes. Medical Education. 38 (5), 510-521. 
16. Seeleman C, Suurmond J, Stronks K.. (2009). Cultural competence: a conceptual framework for teaching and learning. Medical Education. 43 (3), 229-237.

17. Goldstein AO, Calleson D, Bearman R, Steiner BD. (2009). Teaching Advanced Leadership Skills in Community Service (ALSCS) to Medical Students. . Academic Medicine. 84 (6), 754 -764.

18. Halaas GW. (2005). The Rural Physician Associate Program: New Directions in Education for Competency Education for Health. Education for health. 18 (3), 379- 386.

19. Eddey GE, Robey KL. (2005). Considering the culture of disability in cultural competence education. Academic Medicine. 80 (7), 706 712.

20. Calvillo E, Clark L, Ballantyne JE, Pacquiao D, Purnell LD, Villarruel. (2009). Cultural Competency in Baccalaureate Nursing Education.Journal of Trans cultural Nursing. 20 (2), 137-145.

21. Barss P, Grivna M, Al-Maskari F, Kershaw G. (2008). Strengthening public health medicine training for medical students:

Development and evaluation of a lifestyle curriculum. Medical Teacher. 30 (9-10)

22. el Ansari W, Russell J, Spence W, Ryder E, Chambers C. (2003). New skills for a new age: Leading the introduction of public health concepts in healthcare curricula. Public Health. 117 (2), 77-87.

23. Crampton P, Dowell A, Parkin C, Thompson C. (2003). Combating effects of racism through a cultural immersion medical education program. Academic Medicine. 78 (6), 595-598.

24. Markenson D, DiMaggio C, Redlener I. (2005). Preparing health professions students for terrorism, disaster and public health emergencies: core competencies. Academic Medicine. 80 (6), 517526.

25. Doran KM, Kirley K, Barnosky AR, et al. (2008). Developing a novel Poverty in Healthcare Curriculum for Medical Students at the University of Michigan Medical School. Academic Medicine. 83 (4), $5-13$.

26. Reynolds PP, Kamei RK, Sundquist J, Khanna N, Palmer E, Palmer T. (2005). Using the PRACTICE Mnemonic to Apply Cultural Competency to Genetics in Medical Education and Patient Care. Academic Medicine. 80 (12), 1107 - 1113. 
27. Tervalon M. (2003). Components of culture in health for medical students' education. Academic Medicine. 78 (6), 570-576.

28. Betancourt Joseph R. Cross-cultural Medical Education: Conceptual Approaches and Frameworks for Evaluation. Acad. Med. 2003; 78:595-598.

29. Peter HK, Herbert MS. (2006). Medical Education for a Changing World: Moving Beyond Cultural Competence into Transnational Competence. Academic Medicine. 81 (2), 548-556.

30. Ana E. Nunez. (2000). Transforming cultural competence into cross-cultural efficacy in women's health education. Academic Medicine. 75(11), $1071-1080$.

31. Strasser S, London L, Kortenbout E. (2005). Developing a Competence Framework and Evaluation Tool for Primary Care Nursing in South Africa. Education for Health. 18 (2), 133-144.

32. Michener JL, Yaggy S, Lyn M, et al. (2008). Improving the health of the community: Duke's experience with community engagement. Academic Medicine. 83 (4), 408-413.

33. Abrams SE. (2004). From Function to Competency in Public Health Nursing: 1931 to 2003. Public Health Nursing. 5 (21), 507 -510.

34. Albanese MA, Mejicano G, Mullan P, Kokotailo P, Gruppen L. (2008). Defining characteristics of educational competencies. Medical Education. 42 (3), 248-255.

35. Dussault G, Franceschini MC. (2006). Not enough there, too many here: understanding geographical imbalances in the distribution of the health workforce. Human Resource Health. 12 (4), 1478-4491

36. Tanner C. (2004). Competency-based education: The new panacea? Journal of Nursing Education. 40 (9), 387-388

37. Magzoub M E, Schmidt HG, Abdel-Hameed A, Dolmans D, Mustafa SE. (1998). Student assessment in community setting: a comprehensive approach. Medical Education. 32 (1), 50-59.

38. Maeshiro R, Johnson I, Koo D, Parboosingh J, Carney JK, Gesundheit N. etal. (2010). Medical education for a healthier population: Reflections on the Flexner Report from a public health perspective. Academic Medicine .85 (2), 211-219

39. Merl PA, Csanyi GS, Petta P, Lischka M.(2000). Competencies at the University of Vienna Medical School. Medical Education. 34 (3). 
40. Magzoub ME, Schmidt HG. (2000). A taxonomy of community based medical education. Academic Medicine. 75 (7), 699-707.

41. Boelen C. (1992). Medical education reform: the need for global action. Academic Medicine. 67 (11), 745-49.

42. Schmidt H, Magzoub M.E (1997). Assessment of students in community settings. Maastricht: Network, CA. 


\section{Chapter 3}

\section{Does community health care require different competencies from physicians and nurses?}

Zahra Ladhani, Fred C.J. Stevens, Albert J.J.A. Scherpbier

Submitted 


\section{ABSTRACT}

\section{Background}

In Health Professionals Education, the competency based approach has gained a lot of popularity. For community settings it has specific relevance as often fully functional health teams are not available to provide comprehensive care to the populations, and the health providers who work in such isolated settings need not only be competent in their own professions but also must be able to perform the roles of health team members who are not available.

\section{Methods}

This study examined the specific tasks of health providers and variations in their competencies in a context where there is a structural scarcity of community health care workers. In-depth Interviews of 11 Physicians and 06 Registered Nurses (RNs) working in community settings of Pakistan were conducted along with review of their job descriptions.

\section{Results}

The most frequently required competency for physicians is "direct patient care" and for nurses it is either "public health" or "administration". Location of health facility or level of care does not demand different competencies, however depending on the employer the required competencies do vary. The critical factors in determining the tasks performed by health providers were availability of a functional health team and the preparation of health providers for CBE competencies.

\section{Conclusions}

The specific tasks of physicians and RNs working in community settings provide a useful framework to analyze competencies, and can help educators revisit the curricula and instructional designs. The results provide important insights into the practice of community health provision which should be utilized by educators and policy makers alike 
for the production and deployment of aptly, competent healthcare providers.

\section{Key Words}

1. Competencies

2. Community settings

3. Undergraduate Curriculum

4. Health care Providers

5. Tasks \& functions 


\section{INTRODUCTION}

The rise of the competency-based approach in health professional education (HPE) has sparked curricular reforms that are currently being tested in institutions for nursing and medical education. Testimony to the growing popularity of this educational approach is its endorsement in the Lancet by the global independent Commission on the Education of Health Professionals for the $21^{\text {st }}$ century, which welcomes it as "a disciplined approach to specify the health problems to be addressed, identify the requisite competencies required of graduates for health system performance, tailor the curriculum to achieve competencies, and assess achievements and shortfalls. ${ }^{\text {[1] }}$ The commission furthermore suggests that "a potentially transformative use of competencies would be to serve as an objective basis for classification of the various health professions." ${ }^{[1]}$ Competencies describe functional and behavioural qualities that enable health professionals to provide effective health care. Each function in a health care organisation requires a certain mix of competencies to be performed by individual care providers or, more effectively, by a team, as is increasingly common in clinical settings like secondary and tertiary hospitals, where team members have distinct roles and responsibilities. For competency-based HPE to be effective it is important that it is designed to equip health providers with appropriate competencies to meet the health care needs of populations. Unfortunately, in community settings there is growing evidence that the roles to be fulfilled by health providers tend to be described less clearly, particularly at the level of primary care where a multidisciplinary, functional health team is generally 
lacking and facilities are run single-handedly by a physician or a nurse or, in many instances, by a paramedic who - albeit untrained - is expected to provide the full spectrum of services. So, it appears that on one hand there is an urgent need to tailor education to community needs while on the other hand there is no substantial evidence that in community settings clear demands are made of health providers in terms of competencies.

In Pakistan in particular, where this study was done, the issue of the availability of competent health teams is acute and complicated. To begin with, community facilities in the public sector - the major health care provider - have positions for physicians and paramedics but not for nurses. Secondly, not many physicians opt to work in community facilities, leaving a vast number of facilities to be run by paramedics or, even worse, without any staffing at all. Finally, physicians working in community settings are not competent to provide the full range of services required in a community setting, as they are trained in tertiary care settings where their role in the health care team is limited to diagnosing and treating clinical patients. ${ }^{[2-4]}$ In our earlier study we found through systematic review that Community Based Education (CBE) should focus on competencies relating to Public Health, Leadership \&Management, Community Development \& Advocacy, Research, Evidence Based Practice and Cultural and Generic Competencies. ${ }^{[5]}$ In the present study we investigated whether these competencies are identifiable in the practice of community care, whether they are affected by impeding factors and whether they are recognised by various stakeholders including the health 
professionals themselves. The study also explored potential variations in competencies between different settings, in light of a WHO report on health workforce strengthening, that cautioned, "HPE approaches and human resource planning that focus on the training of individuals without taking into account the work environment and mobility will have limited success. Scaling up education in an isolated way will not compensate for addressing the increasing challenges for health workforces, such as shortages, imbalances, educational quality and productivity concerns.." ${ }^{[6]}$ To support efforts for designing and delivering effective education for health professionals working in community settings we explored and documented professionals' views regarding the practice of community care and variation in tasks between settings. The results are expected to add to the existing knowledge about relevant and coherent HPE strategies to train health providers who are equally competent to work in all health care settings. We specifically addressed the following research questions:

1. Do community settings require different sets of competencies for physicians and registered nurses?

2. What variations exist in the competencies of physicians and registered nurses working in rural, urban and semi urban community settings?

3. What variations exist in the competencies of physicians and registered nurses working in community facilities run by the government, non-governmental organisations (NGOs) or universities? 


\section{METHODS}

\section{Background and setting:}

The Research Ethics Committee of the Shifa Colleges of Medicine and Nursing, Islamabad, Pakistan where the primary author was employed, approved the study protocol. The study was conducted in community settings in two major cities of Pakistan - Karachi and Islamabad - and the surrounding towns/villages. These settings were purposely selected for their easy accessibility and the presence of a large number of government and NGO facilities as well as medical universities, particularly ones with teaching sites in urban slums.

In this paper, 'community settings' refers to health facilities providing care at primary or secondary level. Services at primary level include basic preventive care for mothers and children under five years and curative care for common illnesses as identified by WHO for populations of around 10,000 - 25,000. Staff at primary level comprises: a physician, a lady health visitor (a health worker with two years of training in maternal and child health care), a vaccinator and a team of community health workers. Secondary care includes all services offered at primary level with the addition of specialised curative care, minor surgery, labour and delivery, obstetrics and neonatal emergency care, laboratory and facilities for investigations such as X-rays and ultrasound for a catchment population of 25,000 - 50,000 provided by staff comprising a physician with administrative responsibilities, medical specialists, RNs (a few locations only), auxiliary staff and a team of community health workers. ${ }^{[2,7]}$ 
The term 'health care providers' is used with reference to physicians with at least a bachelor of medicine (MBBS) degree and registered nurses (RNs) with a diploma or bachelor's degree working in community settings. For inclusion in the study we selected health care providers from the three major types of community care facilities in Pakistan: government and non-governmental organisations (NGOs) and medical universities. It was difficult to recruit RNs as very few RNs are employed in community settings ${ }^{[4]}$ and no official data is available on the number of community health nurses (CHNs). It is roughly estimated that out of $52,000^{1} *$ nurses registered in Pakistan some thirty to forty work as CHNs. ${ }^{[8]}$ In the public sector there is no designated position or career structure for RNs in community settings, although a recent pilot programme has introduced the position of staff nurse at the secondary level of community care in ten districts (out of 136). One of these RNs was included in the study. Most of the RNs participating in the study worked in three organisations (one private medical university and two NGOs) that are recognised for their community based health care, and employ RNs as CHNs.

\section{Sample and Data Collection:}

We selected twelve health care facilities representing a mix of rural, semiurban and urban facilities at primary and secondary level of care and run by government, NGOs and medical universities. Of these facilities, six

\footnotetext{
$1 *$ The figure represents the number of registered nurses which had trained in the country and were registered with the Pakistan Nursing Council in November 2012. There is no data on the exact number of nurses currently in the workforce.
} 
employed an RN, all of which participated in the study. Of twenty physicians employed by nine facilities, eleven were randomly selected to participate in the study, bringing the total number of participants to seventeen.

To collect and analyse the data we used a mixed method approach including in-depth interviews and document review. Written consent was obtained from all participants before the interviews:

1. In-Depth Interviews (IDIs): The principal investigator conducted face-toface interviews with all participants at their place of work using a semistructured guide containing few close ended questions- such as respondents education background, designation, total number of years of experience, length of working in current position etc. and a number of open ended questions pertaining to health providers' daily routine including their tasks and functions, primary and secondary responsibilities, average time spent on each tasks, difficult and easy to perform tasks etc. along with a pre-set list of tasks for probing. Verbal consent was obtained from all participants; the interviews were tape recorded and the interviewer noted important points and observations.

2. Document review: In order to compare job expectations and practice, we reviewed job descriptions of physicians and RNs working in community settings that were obtained from the participants' employers.

\section{DATA ANALYSIS}

The recordings of the interviews and the documents were imported in Nvivo 9, qualitative research software which we used to organise and analyse the data. After listening to and reviewing the recordings, the 
principal researcher prepared detailed summaries of the interviews and drafted initial inductive codes. After refining and revising the codes in consultation with two of the other authors, the principal researcher reread the data assigning and categorising codes to generate themes. A framework matrix from the software was used to analyse the task descriptions. Variations in tasks were recorded and analysed from four perspectives: professional (physicians and RNs); geographical (rural, semi urban and urban); level of care (primary and secondary); employers (government, NGO, university).

\section{RESULTS}

Seventeen health care providers from twelve facilities were interviewed. They were all mid-level professionals (Table 1). Three of the facilities employed nurses as well as physicians, six employed only physicians and three only RNs. The government run facilities employed more male physicians, while the university and the NGO facilities employed more female physicians. Most of the university-based physicians worked in the community setting as part of their residency training in family medicine. All employers provided clearly defined role descriptions for the physicians. In the government and non-government facilities the main tasks were direct patient care and administration and management, while in the university setting the main tasks were teaching combined with patient care. Universities and NGOs provided well defined role descriptions for RNs; at primary level facilities, RNs provided preventative and health promotion services at health facility and household level, health facility management and supervision of community health workers 
(CHWs). At secondary level facilities, the role of $\mathrm{CHNs}$ included also training and supervision of auxiliary staff and $\mathrm{CHWs}$ and networking with other health providers.

Table 1: Participants' demographic and employment data

\begin{tabular}{|c|c|c|c|c|c|}
\hline $\begin{array}{l}\text { Position \& Primary } \\
\text { Responsibilities }\end{array}$ & Education & $\begin{array}{l}\text { Years of } \\
\text { experience in } \\
\text { health care }\end{array}$ & Employer & $\begin{array}{l}\text { Place of } \\
\text { work }\end{array}$ & Level of care \\
\hline $\begin{array}{l}\text { Medical officer (MO) } \\
\text { Role: Direct patient care }\end{array}$ & MBBS & 5 years & Government & Rural & Primary \\
\hline $\begin{array}{l}\text { MO - In charge } \\
\text { Role: Admin \& } \\
\text { Management; Direct } \\
\text { patient care }\end{array}$ & MBBS & 10 years & Government & Rural & Secondary \\
\hline $\begin{array}{l}\text { MO } \\
\text { Role: Direct patient care }\end{array}$ & MBBS & 10 years & NGO & Urban & Secondary \\
\hline $\begin{array}{l}\text { MO } \\
\text { Role: Direct patient care }\end{array}$ & MBBS & 2 years & University & Rural & Primary \\
\hline $\begin{array}{l}\text { Senior } \mathrm{MO} \\
\text { Role: Teaching, } \\
\text { Direct patient care }\end{array}$ & $\begin{array}{l}\mathrm{MBBS}+{ }^{* *} \mathrm{FCPS} \\
\text { family medicine }\end{array}$ & 8 years & University & Semi Urban & Secondary \\
\hline $\begin{array}{l}\text { Assistant Professor } \\
\text { Role: Admin \& } \\
\text { Management, Teaching }\end{array}$ & $\begin{array}{l}\mathrm{MBBS}+\mathrm{FCPS} \\
\text { family medicine }\end{array}$ & 10 years & University & Semi Urban & Secondary \\
\hline $\begin{array}{l}\text { Staff nurse } \\
\text { Role: Direct patient care }\end{array}$ & $\begin{array}{l}\text { Diploma in } \\
\text { Nursing }\end{array}$ & 2 years & Government & Rural & Secondary \\
\hline $\begin{array}{l}\text { Community Health Nurse } \\
\text { Role: Preventative, Admin } \\
\text { \& Management }\end{array}$ & BSc. Nursing & 5 years & University & Rural & Secondary \\
\hline $\begin{array}{l}\text { Community Health Nurse } \\
\text { Role: Preventive, Direct } \\
\text { patient care, Admin \& } \\
\text { Management }\end{array}$ & BSc. Nursing & 7 years & NGO & Rural & Primary \\
\hline $\begin{array}{l}\text { Field officer } \\
\text { Role: Admin \& } \\
\text { Management }\end{array}$ & BSc. Nursing & 10 years & NGO & Rural/ Urban & $\begin{array}{l}\text { For a number } \\
\text { of facilities }\end{array}$ \\
\hline
\end{tabular}

** FCPS $=$ Fellow of College of Physicians and Surgeons 
One of the RNs was a field officer supervising and managing health staff of a total of twenty health facilities. Although there was no official job description, the job of $\mathrm{RN}$ in the government facility was expected to include assisting physicians in providing direct patient care.

Competencies of physicians and RNs working in community settings At the time of data analysis, the responses generated from the questions pertaining to the tasks and functions performed by health providers were enlisted and mapped under an appropriately fitting competency which had resulted from our earlier study5 (Public Health, Leadership \& Management, Community Development \& Advocacy, Research, Evidence Based Practice and Cultural and Generic Competencies). In addition to the competencies identified earlier, we have also listed "Direct patient care" as one of the competency cluster since it emerged in our present study as most frequently performed tasks particularly by the physicians. Moreover, we found that tasks under "Cultural and Generic" competencies are cross cutting in all settings and level of care, as one participant said, they are "interwoven with whatever I do." Table 2 presents each competency along with cluster of corresponding tasks and functions identified by the respondents in their interviews. 


\section{Table 2: Competency clusters with its corresponding tasks and}

\section{functions}

\begin{tabular}{|c|c|}
\hline Competencies & Corresponding Tasks/ Functions \\
\hline \multicolumn{2}{|l|}{ Functional Competencies } \\
\hline Public Health & $\begin{array}{l}\text { Preventive activities, Health promotion, Health education, Screening, } \\
\text { Surveillance, Outreach, Case finding and care, Social marketing, Mass } \\
\text { vaccination campaigns (national polio days), School health services, } \\
\text { Maintaining information system. }\end{array}$ \\
\hline Direct Patient Care & $\begin{array}{l}\text { "Being a doctor": History taking \& recording, Physical assessment, } \\
\text { Diagnosing, Prescribing, Minor surgery, Basic lab works, Making referrals } \\
\text { and Emergency care. } \\
\text { "Being a nurse": Assisting physician, Nursing procedures, Diagnosing and } \\
\text { prescribing for common illnesses, Recognising high risk cases \& referrals, } \\
\text { Home based management of chronic illness, First Aid, Conduct normal } \\
\text { delivery, Assess \& Resuscitate new born and Post natal care. }\end{array}$ \\
\hline $\begin{array}{l}\text { Leadership and } \\
\text { Management (All tasks } \\
\text { identified pertain to } \\
\text { Administration) }\end{array}$ & $\begin{array}{l}\text { "Being an administrator": Administration, Conflict Management, } \\
\text { Budgeting, Planning and Overseeing implementation of activities, } \\
\text { Organising events, Knowledge of and connections with resources and } \\
\text { referral services, Chairing or attending meetings, Liaison with } \\
\text { management, Maintaining records/reports, Coordination. }\end{array}$ \\
\hline $\begin{array}{l}\text { Research (mentioned by } \\
\text { three participants) }\end{array}$ & $\begin{array}{l}\text { Data collection, Training and Supervision of data collectors, Ensure data } \\
\text { quality, Review data and Prepare reports. }\end{array}$ \\
\hline Teaching and Learning & $\begin{array}{l}\text { "Being a teacher": Coaching, Mentoring, Supervision, Training-Needs- } \\
\text { Assessment (TNA), Preparing training courses, On-the-job training in } \\
\text { clinical and generic skills for community health workers, Giving feedback. }\end{array}$ \\
\hline $\begin{array}{l}\text { Community } \\
\text { Development and } \\
\text { Advocacy }\end{array}$ & $\begin{array}{l}\text { Identifying volunteers, Organising community based groups, Facilitating } \\
\text { community representatives for networking with other providers, Help } \\
\text { build trust of community in health services/team. }\end{array}$ \\
\hline \multicolumn{2}{|c|}{ Generic Competencies (Cutting across all functional competencies) } \\
\hline \multirow[t]{2}{*}{ Cultural Competence } & $\begin{array}{l}\text { Knowing \& Speaking the same language (or finding an interpreter to } \\
\text { understand patients' complaints); Understanding health and illness beliefs } \\
\text { and practices; Providing culturally acceptable/appropriate care. }\end{array}$ \\
\hline & $\begin{array}{l}\text { Communication: verbal and written } \\
\text { Counselling, Report writing /documentation, Negotiation, Presentation } \\
\text { and facilitation. }\end{array}$ \\
\hline
\end{tabular}




\section{Competency variations between health care providers:}

During the interviews, respondents were also asked to express the frequency of tasks which they usually perform on a routine day at their workplace in terms of percentage; these were later aggregated to calculate average frequency of tasks performed by the health provider in health care settings.

We found that Direct Patient Care was mentioned as most frequently performed task by physicians -one respondent puts it "I' $m$ a doctor and to see patients is my job." Administration that included tasks like budgeting, planning and overseeing the implementation of activities, organising events, chairing meetings etc. came second for physicians working in government settings. Tasks pertaining to Teaching \& Training were equally recurrent among their university employed counterparts.

The RNs ( $\mathrm{N}=5$ out of $\mathrm{N}=6$ ) working in $\mathrm{NGO}$ and University settings mentioned tasks clustered under Public Health as most frequently performed, whereas in government setting "Direct patient Care" in terms of assisting physicians is the most frequently performed tasks by RNs. Administrative task are second most performed tasks by RNs in all settings. The tasks under "Community Development and Advocacy" are not frequently performed in any setting, however occasionally RNs in NGO and University settings are performing these tasks. Research was not mentioned as a task or responsibility, but physicians as well as RNs described research as an important activity for their career development. Two RNs and one physician were concerned that their role in research was limited to data collection and that they were not regarded as members of the research team. 
Table 3: Frequency of tasks and functions performed by health care providers in different employer settings

\begin{tabular}{|c|c|c|c|c|c|c|}
\hline \multirow[t]{3}{*}{$\begin{array}{l}\text { Tasks and } \\
\text { Functions }\end{array}$} & \multicolumn{6}{|c|}{$\begin{array}{l}\text { Frequency of tasks and functions performed in } \\
\text { Percentage* }\end{array}$} \\
\hline & \multicolumn{2}{|c|}{ Government } & \multicolumn{2}{|c|}{ NGO } & \multicolumn{2}{|c|}{ University } \\
\hline & Physician & Nurse & Physician & Nurse & Physician & Nurse \\
\hline $\begin{array}{l}\text { Direct Patient } \\
\text { Care }\end{array}$ & $75 \%$ & $50 \%$ & $75 \%$ & $25 \%$ & $50 \%$ & $20 \%$ \\
\hline Public health & $10 \%$ & $20 \%$ & $20 \%$ & $60 \%$ & $20 \%$ & $60 \%$ \\
\hline $\begin{array}{l}\text { Leadership and } \\
\text { Management } \\
\text { (Administration) }\end{array}$ & $50 \%$ & $30 \%$ & $20 \%$ & $40 \%$ & $10 \%$ & $40 \%$ \\
\hline Research & NP** & NP & NP & NP & $10 \%$ & $10 \%$ \\
\hline $\begin{array}{l}\text { Teaching and } \\
\text { Learning }\end{array}$ & $10 \%$ & $5 \%$ & $10 \%$ & $30 \%$ & $50 \%$ & $30 \%$ \\
\hline $\begin{array}{l}\text { Community } \\
\text { development } \\
\text { and advocacy }\end{array}$ & $5 \%$ & NP & $10 \%$ & $25 \%$ & $5 \%$ & $25 \%$ \\
\hline
\end{tabular}

*Percentages presented in the table are an average and do not add up to $100 \%$ as these were performed simultaneously.

**NP: Not performed

Overall, variation in tasks performed by health providers is mostly observed between employers than location or health providers.

Table 3 presents the tasks using the same competency cluster as in Table 2 and performance frequency of these tasks by health providers working for various employers in different settings. 


\section{Preparation for community health tasks:}

Participants were asked about their preparation for work in community settings. They were asked how well prepared they were on starting their job (Figure 1); where they had learned the required skills (Figure 2) and what facilitated or inhibited the acquisition of the required competencies.

Figure 1: Preparation of health providers with respect to the CBE competencies

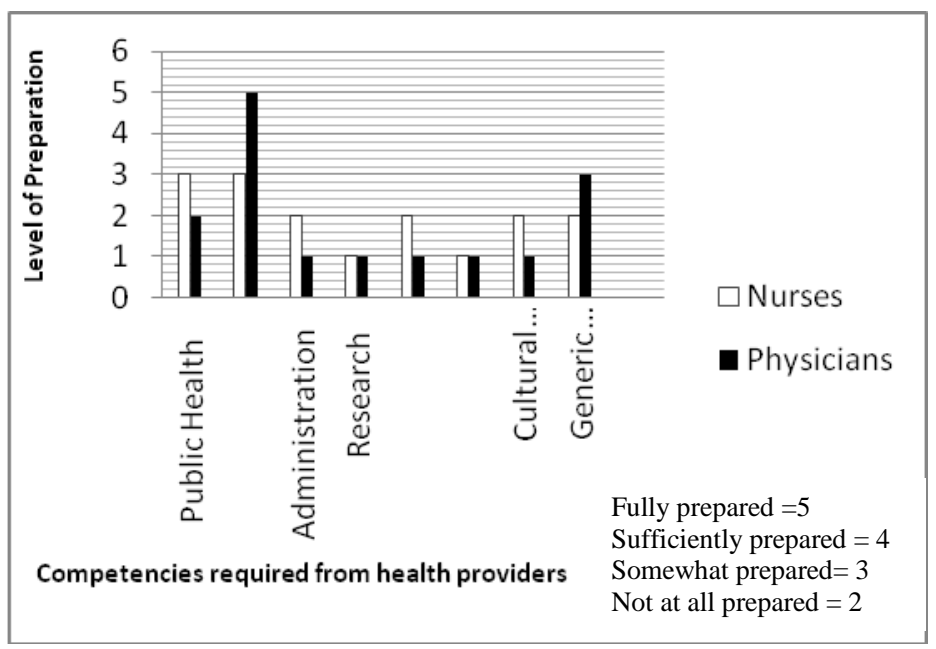

Ten physicians said their hospital-based undergraduate training had not given them opportunities to learn the skills they were expected to perform in the community setting. Similarly, all nurses indicated that their basic training had not equipped them with specific skills for the job, but they received practical on-the-job training to learn those skills. Most importantly however, all except one of them said they continued to learn because an attitude of lifelong learning had been instilled in them during 
their basic training. All physicians indicated that their training had prepared them well for Direct Patient Care. Both RNs and physicians reported a lack of preparation for Research and Community Development and Advocacy.

Figure 2 shows that health providers had acquired most of the competencies through in-service training programmes organised by their employer or through formal or informal training in a previous job. Undergraduate training had prepared the physicians for Direct Patient Care only and RNs for Public Health as well. None of the participants reported having received any dedicated training in competencies for the community setting.

Figure 2: Sources of the acquisition of competencies

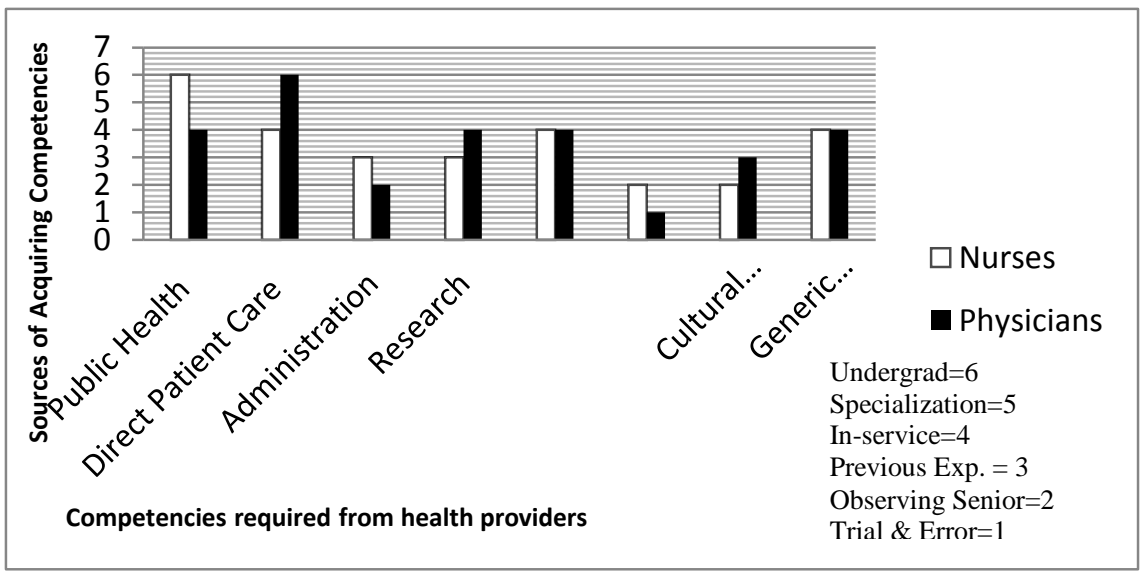




\section{DISCUSSION}

The interviews and the job descriptions indicated that Direct Patient Care was the core task of the physicians while the RNs had primarily preventive or administrative tasks. Although the catchment population and the number of services provided differed between locations and levels of care, there was no concomitant variation in tasks. Slight variations in job descriptions were observed between employment settings, with patient care being considered the primary task in government and NGO settings while in the university setting teaching was prioritised. In government and NGO settings administration was the second most important task. The main factor determining task variation, however, was not location or level of care but health providers' preparation for the CBE competencies and the availability of a multi-professional team consisting of a physician, RNs, administrator, allied health professionals and CHWs. In teams, different members had distinct roles and were expected to perform the competencies described in their job description. In health facilities where there was no designated position for RNs, employers recruited women from the local community to assist physicians in providing curative services, and in such cases, all other tasks were compromised. Where physicians were not available or attended clinic for a few hours only, administrative and patient care tasks including curative services were delegated to RNs.

Our exploration suggests that the CBE competencies identified in our earlier study ${ }^{[5]}$ were not fully performed in the practice of community care. Although it is generally recommended that the emphasis in 
community care should shift from curative care to health promotion and prevention, the participants identified direct patient care as their central and primary task and reported having difficulty performing tasks like teaching and administration/management, which they learned over time either through formal in-service training or informally by observing colleagues. Our data suggest that this may be due to health providers receiving no formal training in these competencies. Even though the nursing curriculum offers courses like "Principles of teaching and learning" and "Administration and management", it is not clear how the skill aspects of these competencies are translated to health care practice, particularly in community settings.

Since the challenges of health care and the complexities of health determinants are not always adequately met by the traditional roles of health providers, it is advocated in the literature to give more prominence to health education, counselling and support services as crucial roles in contemporary health care. ${ }^{[9]}$ In order to be effective agents of change in health care it is also critical for health providers to acquire competencies such as "Leadership \& Management", "Research \& Evidence Based Practice" and "Community Development \& Advocacy". Goldstein et al. ${ }^{[0]}$ support the recommendation by the Institute of Medicine that "increased physician leadership and opportunities for leadership training would help redesign the health care system for the 21st century." Similarly, El Ansari et al. ${ }^{[11]}$ identify strategic leadership as one of the core public health standards, implying that health providers should be educated to develop, sustain and implement a vision and objectives for health. Apart from 
providing leadership, health providers working in community settings are also well placed to link academia with the health care system. If appropriately trained, health providers in community settings can help train other health professionals and undergraduate students ${ }^{[12]}$ to achieve the transfer of skills such as communication, counselling, health education and advocacy as these skills require one-on-one supervision and are not feasible to teach in busy, tertiary hospitals. Prideaux ${ }^{[13]}$ and Irby $^{[14]}$ too, provide evidence that clinicians working in community settings can be effective role models, supervisors and teachers.

Despite the need for competencies other than direct patient care, such as those included in the CanMEDS ${ }^{[15]}$ roles and the competencies identified by the Accreditation Council for Graduate Medical Education -USA ${ }^{[16]}$ or WHO' "Five Star Doctor" ${ }^{[17]}$, the participants indicated that a number of competencies for community care are not yet incorporated adequately in HPE. On top of performing tasks without adequate preparation, some of the participants appeared to perform tasks without being legally licensed to do so. In Pakistan, RNs are neither trained nor licensed to prescribe, but on probing RNs mentioned learning this skill on the job. In the absence of physicians they had no choice but to intervene. This phenomenon was observed in South Africa by Strasser et al. as well. ${ }^{[18]}$, prompting the recommendation that undergraduate training should prepare primary care nurses to provide all services including medical diagnosis and prescribing. Otherwise the population would continue to be deprived of critical health services. 
Another interesting observation by the participants was the difficulty of working in rural areas where the population was poor and uneducated. Health providers working for government run facilities also mentioned other factors adding to the challenge of opting for work in community settings: lack of resources, safety issues, being alone without any professional support or advice, no one to 'check' on them, social isolation and limited or no control over factors directly or indirectly affecting the health care of the population. Health providers preferred to work with NGOs even if it meant working in a remote village because they had access to resources, professional advancement and community support. This finding was evident during the data collection visits and was also reported in other studies highlighting the reluctance of physicians to work in remote areas, especially in the public sector. ${ }^{[2,3,19]}$ Clearly, this situation calls for major efforts to reform HPE, with educators and policy makers joining forces to reduce the gap between academia and the health care system to ensure that health providers are equipped with competencies that enable them to meet the needs and demands of community settings.

\section{CONCLUSION}

Though this study was conducted in Pakistan, the issues addressed are pertinent to HPE institutions elsewhere planning to introduce a competency-based approach. Exploring the specific tasks of physicians and RNs in community settings can identify relevant competencies and related issues and help educators to (re)design curricula that contribute to the provision of appropriate community health care. The results provide insight into some critical facts. Firstly, the current generation of 
health providers are not well prepared by education and training to provide comprehensive care to the general population. Secondly, in community settings there are many synergies between the competencies of physicians and nurses. At the same time these two groups offer distinct sets of services, which should be harnessed to build effective, nonhierarchal, collaborative health teams. Finally, educators and policymakers should collaborate to train health professionals that are equipped with appropriate competencies and to create attractive opportunities in community settings to induce health providers to opt to work there. In short, education and health policy should join forces to ensure that populations receive the best of care from all members of the health team.

\section{REFERENCES}

1. Julio Frenk, Lincoln Chen, Zulfiqar A. Bhutta et al. “Health professionals for a new century: transforming education to strengthen health systems in an interdependent world". www.thelancet.com Published online November 29, 2010 DOI:10.1016/S0140-6736(10)61854-5.

2. J. Ahemd\& B.T. Shiakh. "The state of affairs of Primary health care facilities' in Pakistan. Where is the state' stewardship?"EMHJ. 2011; 17(7): 619-623.

3. M. Asad Khan. Failure analysis of Primary health Care in Pakistan and recommendations for change. Health Commission report, Insaf Research Wing. (June 2009).

4. Gulzar, S.A. Shamim, M.S., Khuwaja, A.K. Promoting motivation towards community health care: A qualitative study from nurses in Pakistan. J Pak Med Assoc. 2010; 60 (6): 501-503.

5. Ladhani Z., Scherpbier, A.J., Stevens, F.J. Competencies for Undergraduate Community Based Education for the Health 
Professions - A Systematic Review. Medical Teacher. 2012; 39 (9): 733-743.

6. Malaj, A., Dias,C., Miller, S., Galmond, E., (2012) WHO Regional Office for Europe: Toolkit for country health workforce strengthening. Accessed from URL:

[http://www.euro.who.int/en/what-we-do/health-topics/Healthsystems/health-workforce]

7. Health Systems Profile- Pakistan Regional Health Systems Observatory- EMRO. PP 26- 43. Accessed from URL: [http://gis.emro.who.int/HealthSystemObservatory/PDF/Pakista n/Health\%20system\%20organization.pdf]

8. Official Web site of Pakistan nursing council : [http://www.pnc.org.pk/Registration.htm]

9. McDonald, A.L., Langford, I.H., Boldero, N. The future of community nursing in the United Kingdom: district nursing, health visiting and school nursing. Journal of Advanced Nursing. 1997; 26: 257-265.

10. Goldstein, A.O., Calleson,D., Bearman, R., Steiner,B.D. Teaching Advanced Leadership Skills in Community Service (ALSCS) to Medical Students. Academic Medicine. 2009; 84 (6): 754 -764.

11. el Ansari, W., Russell, J., Spence, W., Ryder, E., Chambers, C.,. New skills for a new age: Leading the introduction of public health concepts in healthcare curricula. Public Health. 2003; 117 (2): 77-87.

12. Howe, A., Crofts, D., Billigham, K.. Can nurses teach tomorrow's doctors? A nursing perspective on involvement in communitybased medical education. Medical Teacher. 2000; 22(6): 576-584.

13. D Prideaux\& et al. Clinical teaching: maintaining an educational role for doctors in the new health care environment. Medical Education. 2000; 34: 820- 826

14. Irby D. Teaching and learning in ambulatory settings: a thematic review of the literature. Academic Medicine. 1995; 70: 898 - 931.

15. Frank J R. The CanMEDS 2005 Physician Competency Framework. The Office of Education, Royal College of Physicians and Surgeons of Canada. 2nd ed. Ottawa; 2005

16. Lurie S J, Mooney CJ, Lyness JM, MD. Measurement of the General Competencies of the Accreditation Council for Graduate 
Medical Education: A Systematic Review. Academic Medicine. 2009; 84 (3): 301-309.

17. World Health Organization. Doctors for Health: A WHO Global Strategy for Changing Medical Education and Medical Practice for Health for All. Geneva; 1996.

18. Strasser S, London L, Kortenbout E. Developing a Competence Framework and Evaluation Tool for Primary Care Nursing in South Africa. Educ. Health. 2005; 18(2)133-144.

19. Nazmul Chaudry\& Jeffrey S. Hammer. Development Research Group World Bank. Ghost doctors: Absenteeism in Bangladeshi health facilities -World Bank Policy Research Working Paper 3065, May 2003. 


\section{Chapter 4}

\section{Competence, Commitment and Opportunity: Views of faculty on Community- Based Education (CBE)}

Zahra Ladhani, Fred C.J. Stevens, Albert J.J.A. Scherpbier Submitted 


\section{ABSTRACT}

\section{Background}

Despite the fact that CBE has been included into contemporary Health Professionals' Education (HPE), doubts exist of its success. The literature indicates three major barriers to successful implementation, related to deficient (a) institutional structure, (b) curriculum and (c) human resources. The focus of this study was on human resources i.e. faculty members; the study aimed at exploring the implementation of CBE from faculty' perceptions and practices in context of institutional structure \& systems and curriculum.

\section{Method}

Our sample was drawn from HPE institutes situated in two cities of Pakistan. Focus Group Discussions (FGDs) and In-Depth Interviews (IDIs) were used. We interviewed groups of faculty members from 12 medical and nursing colleges and four key informants including two registrars of the national councils for medicine and nursing.

\section{Results}

Our respondents reported a number of circumstances that hampered effective implementation of CBE. These were either related to their own preparation or to their environment which constituted institutional structure and curriculum. Under the structural barriers, they identified inadequate resource allocation for community based teaching and research, ambiguous reward and promotion structures for community service. In regard to the curriculum, we found that community concepts are insufficiently connected to or integrated with other subjects, and that, the opportunities for contextual learning through community based encounters are also underutilized. Besides these barriers, more than half of the faculty members were not formally trained for $C B E$ and would benefit from faculty development programs on certain important CBE concepts. Moreover, respondents reported insufficient commitment, 
appreciation and sometimes even resistance for CBE, permeating at all levels - regulatory bodies, institutional heads and faculty members.

\section{Conclusions}

To improve CBE and to bring strategic and sustainable change into HPE at large it is required to invest adequately in all three elements: institutional structure, curriculum and faculty and to ensure a balance between these elements.

\section{Key words}

1. Community based education

2. Institutional structure

3. Faculty development

4. Curriculum 


\section{INTRODUCTION}

As Community-Based Education ( $\mathrm{CBE}$ ) has developed over the years, around the globe a variety of CBE models has been introduced ranging from a complete shift of curriculum delivery into the community settings to the incorporation of community health topics within a subject commonly known as Community Medicine and/or Hygiene ${ }^{[1]}$. Although $\mathrm{CBE}$ in one form or another has entered contemporary Health Professional Education (HPE), many continue to harbour serious doubts about the effectiveness of its implementation ${ }^{[2,3,4]}$. These doubts relate mainly to lacunae and deficiencies in HPE institutional structures, curricula and human resources.

The most critical structural issue concerns the lack of teaching methods that are purposefully designed to support CBE or community service, leading to inadequate resource allocation, poor reward structures for community based faculty members and commitment to CBE being little more than paying lip service. ${ }^{[5,6]}$ Evaluating a CBE programme, Kristina et al. identified time allocation as another structural issue, reporting that "curricula are earmarked for CBE, but in practice only about half of that time is used for learning in the community, the rest is taken for lectures and activities in facilities remote from the community ${ }^{[3-4]}$. Thus, despite international academic organisations recognising the importance of community and social orientation of curricula, the conventional curriculum is persisting as the predominant model in HPE. ${ }^{[7]}$

Secondly, it remains questionable whether CBE is truly integrated within HPE curricula. Community-based encounters usually accounts for a very 
small proportion of a medical student's time compare to hospital-based experiences in the clinical years ${ }^{[6]}$; moreover these are not made relevant to the requirements of practice. Umer et al. ${ }^{[8]}$ stated that "although $69 \%$ of the doctors had visited the rural health facilities during their student life, they are lacking training to work in rural health facilities;" continuing by stating that "students have no community experience and at best gain only superficial knowledge from textbooks. Although a large number of students had visited primary health care facilities, they seldom interacted with rural communities." The recent report in the Lancet by the commission on Education of Health professionals for the $21^{\text {st }}$ century concludes that HPE is not able to address health care challenges, largely because of fragmented, outdated, and static curricula producing illequipped graduates. ${ }^{[9]}$

Thirdly, there is a scarcity of competent and committed human resources for the planning and implementation of $\mathrm{CBE}$, because educators are not properly trained or appraised on the core requirements for CBE. ${ }^{[10]}$ Many faculty members impart, implicitly or explicitly, the belief that hospitalbased learning is superior to community-based experiences. ${ }^{[6]}$ The paucity of community based encounters coupled with this negative attitude towards CBE by faculty ultimately devalues community experiences for students. ${ }^{[3,4]}$ In HPE, faculty has become increasingly important in policymaking and curricular decisions, while at the same time, the broader academic community, including institutional structure and curricula, exerts a very strong influence on the decisions and actions of faculty members. Diane and colleagues suggested that a university's 
mission, well-defined mechanisms and reward structure determine the degree to which community service is valued by faculty. They further stated that the emphasis placed by a university on community service and civic engagement gives direction to faculty members on how and where to devote their time. Hence, alignment and balance between the three elements - institutional structure, curriculum and faculty members - are fundamental to accomplishing the tripartite mission of HPE institutions: preparing effective graduates, providing high quality care to the communities they serve and advancing knowledge through research. ${ }^{[11]}$ Finally, only all three elements together can influence graduates' competence, performance and career choice, which in the case of community/primary health care will ultimately affect the population's access to health care and health status. The triangle in Figure 1 symbolises the connectivity and interdependence of the elements in advancing the HPE mission; the inner circles represent the fit between students (competencies, performance and $\mathrm{CB}$ career choice) and $\mathrm{CB}$ health care and the entire figure shows the direct influence of the three elements: the (larger) school system and structure, the curriculum and faculty/educators. Our study specifically explored the third element: faculty members' perspectives of CBE within the context of institutional structures, systems and the curriculum. We explored faculty members' perceptions and practices in relation to the implementation of CBE in their institutions. We expected that in the discussions, the training needs of faculty would also surface and that these might ultimately be useful in 
guiding evidence-based faculty development activities, locally and in countries with similar situations.

Fig. 1: Elements of HPE institute and impact of its influence

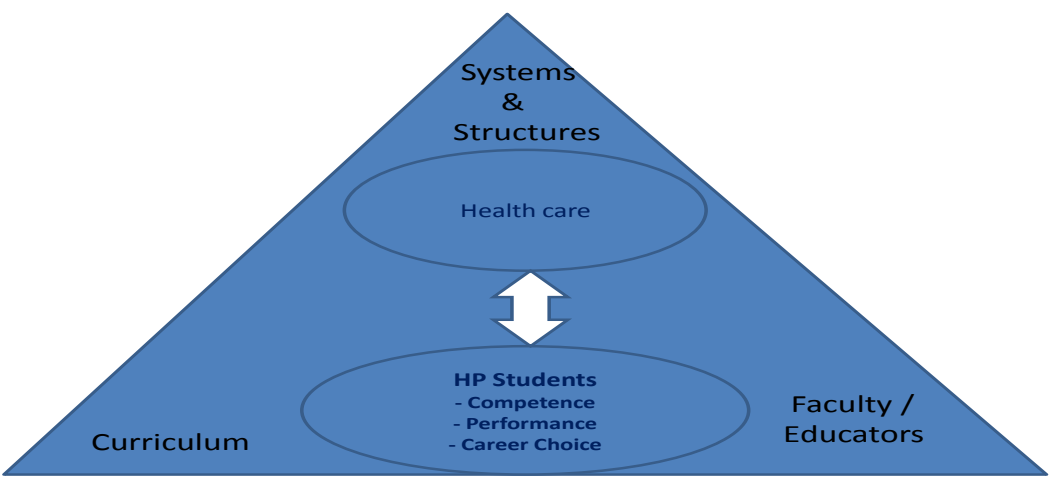

\section{METHODOLOGY}

\section{Ethical approval:}

The study protocol was reviewed and approved by the research ethics committee of Shifa Colleges for Nursing and Medicine, Islamabad, Pakistan. Verbal consent from the participants was obtained at the start of all the interviews.

\section{Design, Sample and Setting:}

A descriptive qualitative study was designed using focus group and indepth individual interviews to elicit perceptions of faculty regarding desirable CBE practices and competencies and to gain an understanding of the underlying perceptions regarding $C B E$. 
To qualify for inclusion in the study HPE institutions had to meet the following criteria: having at least two health professional schools: a medical and a nursing school; having teaching sites in the community/ies; and employing faculty to teach and supervise delivery of the curriculum in the community setting. Based on these criteria, we selected six institutions which were either part of a medical university or of a faculty of health sciences of a general university financed and governed by the public sector, armed forces and private sectors. The sample was taken in two cities of Pakistan - Karachi and Islamabad - and consisted of two public, one armed forces and three private institutions. We conducted a total of twelve focus group interviews, six with medical school faculty and six with nursing school faculty. Additionally, we interviewed two community experts and two registrars of regulatory bodies, i.e. nursing and medical councils. One expert was a senior medical educator involved in initiating CBE in Pakistan and the other was a nursing educator who was amongst the first few nurses to work as a community health nurse in a university prototype health centre and later proposed a career structure for community nurses.

\section{Data Collection:}

Groups of five to six faculty teachers of community health courses in the medical and nursing colleges in our sample participated with permission from their academic leads. The participants were asked to talk about their own academic preparation for $\mathrm{CBE}$; their definition and understanding of $\mathrm{CBE}$; teaching hours and content; satisfaction with the course and its 
outcome; their understanding of $\mathrm{CB}$ competencies and any specific competencies they had defined for the community course.

For the individual interviews a set of open ended questions was prepared; the experts were asked to share their views about practices, difficulties in the implementation of the programme and recommendations for the CBE programme. The registrars were asked about their understanding of $\mathrm{CBE}$, how they personally valued $\mathrm{CBE}$, and the contribution of the regulatory body to ensuring the proper implementation of CBE.

\section{DATA ANALYSIS}

All interviews were conducted by the principal researcher, who took notes and audio recorded the interviews. Since all interviews were conducted in the English language there were no translation issues. The notes were typed up immediately after the interview and, where practically possible, shared with the participants to determine their validity and accuracy. When the notes were approved by the participants, the notes and recordings were imported into qualitative research software - Nvivo 9, which was used to organise and analyse the data. After listening to and reviewing the recordings, the principal researcher prepared detailed summaries and drafted a list of initial inductive codes discussing it with the other two authors for refinement and revision. Using the revised codes, the data was re-read, re-coded and categorised to generate themes. 


\section{RESULTS}

\section{Participant Characteristics:}

A total of 65 faculty members, 28 from nursing colleges and 37 from medical colleges, at different stages in their careers (early career, senior faculty, head of department) participated in a total of twelve focus group interviews. Of the faculty from medical colleges, $65 \%$ worked full time in the community health /medicine department and the others were coteaching family medicine. Two (private) nursing colleges had a group of faculty members dedicated full-time to the community health nursing course whereas the faculty of the other three colleges taught multiple courses. Of the faculty members, $45 \%$ had some sort of formal training (a certificate course or diploma or graduate studies in Public (or community) Health) while the remaining $55 \%$ had not specialised in or prepared otherwise for teaching the community health course or had specialised in other subjects, such as dermatology, internal medicine and family medicine. Of the medical faculty members, $94 \%$ had received their training from a college with a traditional curriculum without any exposure to community settings as an undergraduate student, while $65 \%$ of faculty from nursing colleges had similar undergraduate experiences as their medical colleagues.

\section{Barriers to $\mathrm{CBE}$ :}

During the focus group and individual interviews, participants identified factors and forces that negatively affected the implementation of CBE. These factors were related to their own preparation, to the institutional structure and to the curriculum. 


\section{i. Structural barriers:}

Resource allocation: the (lack of) availability of resources in the form of trained personnel and financing for teaching, service and research activities in the community was identified as a major problem in all types of institutions - public, private, and armed forces. According to participants, college administrations did not consider it necessary to employ staff to coordinate $C B$ activities. In the public institutions the student /faculty ratio was around 50:1; a group from a medical college said: "we (teachers)use only large group teaching formats; even during students' practical training we give lectures because student batches are too large, and there is not enough time allocated for teaching; there are approximately 180 hours altogether, which works out at around 4.5 hours per week and we have to cover syllabi, take exams and mark papers so we have no time left for practical teaching. The conditions are such that we are unable to teach the way we want to: we have no resources, faculty size is adequate for teaching 100 students, but our college enrols 300 students annually; how can we take such a big group for community visits; considering the resources and incentives we get, what we are doing is just fine." With regard to the availability and allocation of resources for CBE a similar comment was made by one of the experts: "issues are also related to resources such as the unavailability of a vehicle, and even if there is a vehicle there is no money for petrol, shortage of trained teachers in schools, shortage of staff in health facilities....."

Faculty roles and rewards policies: Faculty members indicated that their institution's promotion policies heavily favoured clinical research and 
teaching; some faculty members concluded "there is a gap" between expectations and promotion policies, "the college expects them to spend time at the field site and those who do, are not acknowledged in the same manner as faculty doing clinical research or teaching clinical subjects." Some suggested that this (attitude) could only be changed if leadership (national and institutional) would recognise the importance of community service and research.

\section{ii. Curricular barriers:}

Community Health -a standalone subject: According to participants, only $15-20 \%$ of the time in academic programmes (five years for medicine and four years for nursing) was spent on topics related to primary health care, public health, communicable diseases, community assessment and health systems, which are all part of a subject titled "Community Medicine" in medical curricula and "Community Health" in nursing curricula. The public and armed forces colleges follow the curriculum and sequence prescribed by the regulatory body, i.e. the aforementioned topics are spread across the curriculum with the majority of content being taught in fourth year. In most institutions lectures are the main teaching format and paper and pencil exams the usual method of assessment.

There was no institution in which community related content or community-based encounters were planned for the final year in medicine or in case of nursing the last semester. One of the participating nursing colleges had started community electives but had been unable to continue these due to a lack of trained faculty. Moreover, none of the colleges involved community members in their institutional activities or 
academic planning; community participation was sought only for site selection which the faculty members considered important to access the community.

Missed opportunities for contextual learning: Clinical training in the community as prescribed by the regulatory body consisted of "field visits" i.e. a number of day trips to places like a water filter plant, a factory, incineration plant and a primary and secondary care facility, with students being expected to write about their experiences in a "visit book" afterwards. A number of participants indicated that these visits had little or no relevance to the content taught in the classroom and felt that the purpose of a clinical rotation in the community should be to expose students to "real life conditions", considering that most (medical) students are from upper or middle income families and usually have no idea about the living conditions of the mainstream population. They added, however, that even though it was important to "show" students the real setting, it was not always possible to do so, due to reasons beyond their control, such as frequent riots and safety concerns in the city, lack of resources and allocated time being only just enough to "cover" the contents of the course.

Participants from one private institution (nursing and medicine) related contextual learning with community experiences and described that "when we talk about disparity in health care or vulnerable populations in the classroom, students should also see and feel such realities, so that they are prepare to deal with all sorts of populations." Interestingly, a few participants from the same group considered clinical exposure in hospital 
settings as a substitute for community based encounters, justifying this as follows: "students get ample opportunities to interact with patients from poor socio-economic strata as many such patients visit our hospital." Another group said "in our PBL curriculum students learn about the community from the cases that reflect the problems of populations from the field site." They also said "we tell our students about the community, its environment, social factors that affect health etc.; they also learn about epidemiology, biostatistics and research but there is not enough time to apply and practice these skills in the community."

\section{iii. Faculty-related barriers:}

Preparation and competence: A number of respondents shared that do not have formal training on Community based care similarly many of them were neither trained to become teachers nor have received any training on curricular approaches. Several of them had a degree in public health but nevertheless felt unprepared to teach those concepts at undergraduate level. Some of the faculty members were not sure about $\mathrm{CBE}$; according to them $\mathrm{CBE}$ entailed teaching public health and primary health care topics in the classroom and learning about consulting with poor patients. Moreover, their understanding of competencies varied hugely. Some used terms as "attributes" or "values" or "skills" to define competencies, and described it as "in addition to year objectives, which are programme specific, university wide all schools are expected to instil in graduates the same "attributes", such as lifelong learning or critical thinking skills." There was also a group that suggested competencies, such as communication, interviewing (patient and family), negotiation, 
teaching and conducting surveys, as important skills to be learned during community rotations. Yet some members of another group disregarded competencies and said "the most important thing is to learn content and pass exams."

Lack of commitment: almost all focus groups identified lack of commitment and interest from national leadership, i.e. executives of regulatory bodies, as one of the main barriers to $\mathrm{CBE}$. They gave examples like fewer hours dedicated to community medicine/health in the curriculum as compared to clinical subjects, no high-stakes exams, limited funds and lack of activities for faculty development. Two groups shared their concerns over the limited amount of time allotted to $C B$ clinical training and classes; participants from one private medical college, shared their disconcert with the available time in the curriculum, "in fourth year, students spend a total of 8 weeks -3 hours each day for five days (total = 24 hours) in the community, how can our students learn about community?"

The data from the interviews with the experts and registrars of regulatory bodies indicated that academic institutions were not interested and committed to carry forward the agenda of community health; one registrar said: "HPE institutions are required to adopt one BHU (Basic Health Unit) to mutually benefit the community and the students, however except one or two institutions in the country no one else follows this requirement." Another illustration of institutional lack of commitment was from an expert saying: "Even though in the early 1980s a large number of nursing teachers were trained at one of the best universities in Pakistan 
where community nursing was a strong component, once these teachers returned to their own institutions they (teachers) were assigned other tasks instead of allowing them to teach CHN courses."

Resistance to change: One community specialist said that the main reason why CBE was not fully integrated within HPE was that "CBE and PBL both demand and expect that departments are dissolved and the curriculum is integrated within a system, but the problem is that with this change the power of department heads diminishes, and therefore there is a lot of resistance." This phenomenon was also mentioned in some of the focus groups in relation to regulatory bodies. There is no change in the curriculum, revisions are long overdue and "their professional values and practices are misaligned; even though they see the need for change, they do not make it."

\section{Strengthening CBE:}

Numerous suggestions were made by participants for ways to strengthen $\mathrm{CBE}$, such as changes at the institutional level without altering the curriculum. Field visits could be made more relevant and meaningful, for example by introducing visits to rural health care facilities instead of model health centres located close to the institutions. Two groups ventured somewhat more audacious recommendations: increasing $C B$ clinical rotations through electives and mandatory internship in primary health care centres. However, most believed that change was impossible unless the curriculum was revolutionised and the focus of HPE shifted from the hospital to the community. There were others who believed that all changes should be initiated by the regulatory bodies because 
institutions had to follow the directions set by them. One faculty member said: "these (curricular and time division) changes could only be mandated through regulatory bodies, and unless they won't take such steps, there will be no change."

\section{DISCUSSION}

The participants in the study commented on various aspects of CBE and its implementation including barriers set by institutional structure, the curriculum and their own preparation for CBE. The availability of resources for teaching, service or research activities in the community appeared to be a major problem in all types of institutions, a finding that is in conformity with a number of other studies. ${ }^{[3,4,5,12]}$ Joyce and Joanne found that community service commitments were not valued to the same extent as teaching and research, with one of their study participants describing community service as "the stepchild in the tripartite university mission." ${ }^{[5]}$ Bloom contended that a large amount of funding in American medical schools was directed to academic research and specialty medicine and that at the same time there was less funding for community teaching and service. The participants in our study also mentioned that poor reward structures and low priority for community service as well as ambiguity concerning expectations and policies constitute structural barriers. Diane and colleagues ${ }^{[10]}$ reported in a similar vein that "(unidentified) faculty roles and (poor) rewards policies can be barriers to significant and sustained faculty involvement in communities and that faculty are more likely to receive promotion for publishing articles in peer- 
reviewed journals than for demonstrating an active commitment to addressing community problems."

In relation to the curriculum, we found that community concepts were not connected or integrated with other subjects or clinical training. Community based encounters were considered inadequate and having little relevance to the content that was taught. We noticed slight variations between institutions in methods and frequency of community based encounters, but by and large these opportunities were underutilised even though faculty acknowledged that community rotations increased students' understanding of population problems and provided context for their learning. Previous studies also showed that in general CB teaching is undervalued, research is overvalued, and community service is the least valued of activities. ${ }^{[5,10]}$ Aziz et al. ${ }^{[13]}$ reported that "students perceive that current medical school curricula are unable to meet the required standards."

The role of faculty is critical to making CBE work, and our study and many others testify to the fact that this continues to be a challenge, despite considerable investment in faculty development. $[5,10,14]$ Of the participants in our study more than half were not formally trained for CBE. There was also an absence of clarity regarding certain important concepts such as community participation; moreover, none of the participating institutions involved community members in the planning of educational activities, and most faculty members considered community participation only required for selecting field sites. Faculty also had no clear conceptions regarding competencies for health professional 
students in general and for CBE in particular; their description of these competencies underscored the view of $\mathrm{CBE}$ as a mere 'add on' to the 'core' curriculum. Moreover, lack of commitment, appreciation of and resistance to CBE appeared to permeate opinion at all levels - regulatory bodies, institutional heads and faculty members. Apparently, Sam Bloom's analysis of 1988 still holds true: "the themes of community oriented problem based learning encounter deep resistance especially in the way in which new physicians experience the complex modern bureaucracy of medicine, with its rewards and constraints." ${ }^{[7]}$

The perceptions of the participating faculty members suggest that faculty entrusted with the delivery of CBE in HPE might be qualified as "uninformed" and "un-engaged". By "un-informed" we mean that faculty are not properly prepared to deliver $\mathrm{CBE}$, while their views on $\mathrm{CBE}$ are limited and lectures and field trips are considered adequate to meet CBE requirements. By "un- engaged" we mean that faculty are not fully committed to or believe in CBE; they are aware of various CBE models and quote examples, but they consider themselves helpless to bring about any change to enhance $\mathrm{CBE}$ in their own institutions or within the curriculum at large. Moreover, faculty do not appear to have internalised the real meaning of $\mathrm{CBE}$, with many concepts and competencies remaining to them nothing more than empty labels without true substance. It seems that CBE is a patchwork, which has failed to be woven into a coherent and sturdy HPE "fabric".

Our findings suggest that CBE continues to pose a real challenge, and unless institutional structure, curriculum and faculty are strengthened and 
brought into alignment, this situation is unlikely to change. Similar obstacles were found by Lubna et al., ${ }^{[14]}$ who reported about Pakistan that unfortunately CBE could not be perpetuated in the country mainly due to lack of commitment from administration, communication amongst stakeholders and faculty buy in. Furthermore, the perspectives and practices reported by our study participants clearly highlighted a need not only for educating faculty members about CBE concepts and methodologies but also for further research on their attitude towards and motivation for $\mathrm{CBE}$, as faculty will only be able to conduct meaningful transactions with students and other stakeholders, such as community representatives and policy makers, if they themselves believe in the concepts and goals and act as effective role models.

\section{CONCLUSIONS}

The implementation of $\mathrm{CBE}$ in its true sense demands that strategic and sustainable change in HPE at large, i.e. in all three elements - institutional structure, curriculum and faculty - must be well balanced in terms of resource allocation and commitment at all levels. Additionally, considering that informed and engaged faculty members are crucial to the success of any HPE endeavour, it is imperative to invest not only in their training but also in creating mechanisms to harness their interest and enthusiasm to advance the promotion and delivery of CBE.

\section{REFERENCES}

1. Richard R \& Fulup T. Innovative schools for health personnel: Reports of ten schools belonging to the network of community 
oriented education institutions for health sciences. WHO offset publication. 1987; ISB 9241701021.

2. Hays R. Community-oriented medical education. Teaching and Teacher Education. 2007; 23: 286-293.

3. Kristina T.N, Majoor G.D, Van Der Vleuten. Does CommunityBased Education come close to what it should be? A Case Study from the developing world: students' opinions. Education for Health. 2006; 19: $179-188$.

4. Kristina T.N, Majoor G.D, Van Der Vleuten. Does CommunityBased Education come close to what it should be? A Case Study from the developing world: evaluating a program in action against objectives on paper. Education for Health. 2005; 189:208.

5. Joyce $S$, Joanne R. Perceptions of tenured nursing faculty related to decision-making for community service. Nursing Outlook. 2007; 55:202-207

6. Alice A.K \& Stuart J. S. Community-based education: is the effort worth it. Medical Education. 2001; 35:315 \pm 316 .

7. Bloom S.W. Structure and Ideology in Medical Education: An analysis of resistance to change. Journal of Health and Social Behaviour. 1988; 29: 294-306

8. Umer F. et al. Doctors Perception about staying-in or leaving rural health facilities in district Abbottabad. Journal of Ayub Medical College. 2004; 16(2)accessed from: http://www.ayubmed.edu.pk/JAMC/PAST/16-2/umar.htm

9. Julio Frenk, Lincoln Chen, Zulfiqar A. Bhutta et al. Health professionals for a new century: transforming education to strengthen health systems in an interdependent world. www.thelancet.com.2010 November 29; doi:10.1016/S01406736(10)61854-5

10. Diane C, Jordon C, Sarena D S. Community-engaged scholarship: Is faculty working communities a true academic enterprise? Academic Med. 2005; 80: 317-21.

11. Linda P, David E. K, Phyllis C, Peter C, Sharon K. The Culture of Academic Medicine: Faculty perceptions of the lack of alignment between individual and institutional values.J Gen Intern Med. 2009 Dec;24(12):1289-95 doi:10.1007/s11606-009-1131-5. 
12. Larry W.C. et al. Perceptions and valuation of a CommunityBased Education and Service (COBES) program in Uganda. Medical Teacher. 2011; 33: e9-e15

13. Aziz A, Kazi A, Ashraf J, Fatmi Z. Knowledge and skills in Community Oriented Medical Education (COME) self-ratings of medical undergraduates in Karachi. The Journal of the Pakistan Medical Association. 2006; 56 (7): 313-317

14. Lubna B. A, Akram, D.S, Ali S.K. Development of the CommunityOriented Medical Education Curriculum of Pakistan: A Case Report on the national initiative on curriculum development. Education for Health. 2006; 19: $223-228$. 


\section{Chapter 5}

\section{Academic Leadership and Institutional Culture for Community Based Education: An exploration of institutional practices and priorities in Pakistan}

Zahra Ladhani, Fred C.J. Stevens, Albert J.J.A. Scherpbier Submitted 


\section{ABSTRACT}

\section{Objectives:}

The purpose of this study was to explore perspectives of academic leaders and the culture of HPE institutes towards Community Based Education (CBE) in Pakistan, with the hope to increase awareness of academicians and other stakeholders as a first step towards full integration of CBE.

\section{Methods:}

A purposive sample of 13 academic leaders was drawn including deans \& principals of HPE institutes (medical and nursing colleges) and Heads of Community Departments (HODs). Web- based questionnaires were designed that examined opinions, beliefs and practices in the areas of three basic functions of the university/teaching institute: Teaching and learning, Research, and Service to the community. In addition, policies for promotion, reward structures and priorities for allocating resources in support to community health services and $\mathrm{CBE}$ were explored as proxy to identify the (CBE) culture of HPE institutions.

\section{Results:}

Most of the community departments have relatively a reasonable number of teaching faculty members; among them half have post graduate qualification in public health. Regarding their practices, HODs reported that faculty and student activities at the community field sites are limited to consult patients or, at most, health education. Community research is not common, and where a few researches are done these are in isolation. Lack of role models has been identified as one of the major impediments in the implementation of $\mathrm{CBE}$ 


\section{Conclusions:}

Academic leaders have contributed to move CBE agenda in the HPE institutes. Now to comprehensively integrate CBE in HPE, such leadership is required which is prepared to push a paradigm shift, enhancing a "culture" of balanced approach to health care.

\section{Key Words:}

1. Academic leadership

2. Institutional Culture

3. Community Based Education

4. Health Profession's Education 


\section{INTRODUCTION}

Reforms in Health Professions Education (HPE) have mainly focused on the curriculum changes, as these are the most recognizable and easily modified. Other elements of higher education including faculty development, governance and administrative structures are often less comprehensively addressed ${ }^{[1-5]}$. Evidence concerning Community Based education ( $C B E$ ) suggests that despite the resources poured into the implementation of $\mathrm{CBE}$, many continue to doubt about the effectiveness of its implementation, mainly due to deficiencies in HPE institutional structures, lack of commitment from administration, communication issues amongst stakeholders, weak leadership and faculty ownership ${ }^{[5-10]}$. It remains therefore unsure whether faculty staff have internalised the real meaning of $\mathrm{CBE}$, because if not, many concepts and competencies may remain to them nothing more than empty labels without true substance. If CBE is all about competencies and teaching a subject one will not see a change in the program or in the academic environmentwhich would resemble a situation Bloom referred to earlier to as "reform without change" ${ }^{[3]}$.

The notion of achieving HPE's mission involves much more than just curricula. The current movement to develop competencies of health professional graduates rather than pouring the courses and coursework is an important step ${ }^{[6,12]}$, in particular for improving health care in the community. Competency approach in CBE has the potential to emphasize organizational structures and interactions between all stake holders including academicians, community representatives and policy makers. 
For implementation of this movement, it would be critical to analyze the attitudes, beliefs and perceptions of the institutional decision makers and examine the culture of academic institutions over simply evaluating the curricula on its content.

Academic leaders are positioned to influence change at all levels, especially at their own institution where they are authorized to guide the development of mission, goals, policies and structures. They play a key role in not only setting the direction for curricular decisions but also have authority over decisions pertaining to the allocation of resources ${ }^{[11,12]}$. Individual faculty members are usually driven by their own values and beliefs which determines the way they take academic decisions and infuse

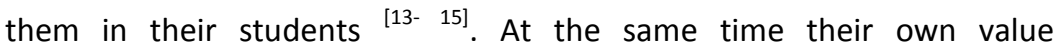
orientations are largely shaped by the institutional culture and the practices of their colleagues ${ }^{[15,16]}$. The role of the academic leader, as suggested by House is to continuously influence, motivate, and enable others to contribute towards the effectiveness and success of the organization ${ }^{[17]}$. The individual mindset (attitude, values, beliefs) is continuously shaped, and how this shaping and reshaping occurs depends crucially on who has how much power and who interacts with whom, in what context, for what purpose, and so forth [18], most of the times this comes from the institutional leaders.

Institutional leadership and culture have become popular topics in management and organizational sciences literature, and are increasingly being recognized as important in educational literature as well ${ }^{[15-21]}$. The term "institutional culture" is used widely in describing the personality of 
institutions. Ravasi and Schultz state that organizational culture is a set of shared mental assumptions that guide interpretation and action in organizations by defining appropriate behavior for various functions ${ }^{[20]}$. Schein believes that culture begins with leaders who impose their own values and assumptions on community members and therefore culture can define leadership in that community ${ }^{[18,19]}$. In a similar vein, for academic culture, Cox et al, suggested that "university leaders attempt to use administrative policies to shape the institution's faculty culture in a way that increases the use of effective instructional practices" ${ }^{[21]}$. Though leadership and institutional culture constructs have been well studied, their importance to the field of higher education in general ${ }^{[15]}$ and HPE in particular has not been established ${ }^{[11,14,22,23]}$. CBE perspectives and practices reported in previous work suggest a need for further research on the attitudes, beliefs and assumptions of the academic

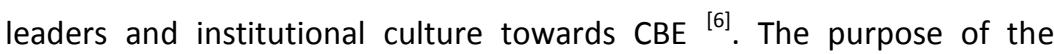
present research therefore is, to explore perspectives of academic leaders and the culture of HPE institutes. By identifying the opinions, beliefs and practices expressed by a purposive sample of academic leaders, we hope that this study will increase awareness of academicians and other stakeholders towards CBE. Hence our questions are:

1. What are the perspectives of academic leadership about CBE? Do these perspectives promote a culture of community service and $\mathrm{CBE}$ ?

2. What attributes of HPE institutes' culture support and promote CBE? 
3. What attributes of HPE institutes' culture will hinder CBE?

\section{METHODOLOGY}

The study protocols were reviewed by the Research \& Ethics Board for Shifa Colleges of Nursing and Medicine, Islamabad.

\section{Questionnaire development:}

We designed two web-based questionnaires to elicit responses regarding opinions, beliefs and practices of respondents in the areas of three basic functions of a university/teaching institute: (a) Teaching and learning, (b) Research, and (c) Service regard to CBE. In addition, policies for promotion, reward structures and priorities for allocating resources in support to community health services and $\mathrm{CBE}$ were explored as proxy to identify the (CBE) culture of HPE institutions.

It was a challenge to design such a tool which can capture the attitudes and deeply held beliefs while ensuring that the questionnaire is short, crisp and to keep most questions as close ended to ensure optimum response from our participants. We could not find any instrument that matched our research agenda; therefore to construct our own questionnaires we reviewed literature on the role of academic leadership, institutional culture and its influence over other elements (faculty, curriculum, structures) of institutes. From the health services literature, the studies that we found were primarily about organizational culture, leadership and decision making styles, change (attitude, creating and management) and reward structures ${ }^{[11,14,15]}$. There were only a handful of studies in HPE that have analyzed faculty development, promotions and 
reward structures for community services and research ${ }^{[13,14,24]}$.The primary author prepared initial drafts and shared with the other two authors, an expert in questionnaire designing and a CBE expert who reviewed the drafts for face and content validity. Before finalization pilot testing of both the questionnaires was done. Table 1 outlines the variables on which the questionnaires were designed; the variables were determined based on the scope of respondents' functions, for example, questions to Deans /Principals were concerned with the college and for HODs it was the community medicine department.

Both questionnaires had two to three questions under each variable altogether there were 25 items out of which $80 \%$ were one liner that examined the extent to which the respondent perceive on a scale of 1-5 that an element was practiced in their institution for e.g. To what extent does your school/college participates in designing national level policies and programs? Another example: To what extent the strategy of your school/college addresses issues of community health? To examine opinions, $15 \%$ of questions had a vignette with multiple choice items and 2 questions were open ended that asked respondents to share their or faculty' experiences of working with communities. 
Table 1: Variables

\begin{tabular}{|l|l|}
\hline Variables for AH questionnaire & Variables for HODs questionnaire \\
\hline $\begin{array}{l}\text { Appreciation / believe in CBE in } \\
\text { general. }\end{array}$ & $\begin{array}{l}\text { Appreciation / believe in CBE in } \\
\text { general. }\end{array}$ \\
\hline $\begin{array}{l}\text { Opinion and satisfaction about } \\
\text { application of CBE in their institute/ } \\
\text { country. }\end{array}$ & $\begin{array}{l}\text { Opinion and satisfaction about } \\
\text { application of CBE in their institute/ } \\
\text { country. }\end{array}$ \\
\hline $\begin{array}{l}\text { Institutional reward and support } \\
\text { structures. }\end{array}$ & $\begin{array}{l}\text { Departmental reward and support } \\
\text { structures. }\end{array}$ \\
\hline $\begin{array}{l}\text { Transferability of CBE goals into } \\
\text { institutional research. }\end{array}$ & $\begin{array}{l}\text { Transferability of CBE goals into } \\
\text { departmental research. }\end{array}$ \\
\hline $\begin{array}{l}\text { Participation/ involvement of } \\
\text { community in institutional decision } \\
\text { making and activities }\end{array}$ & $\begin{array}{l}\text { Participation/ involvement of } \\
\text { community in departmental decision } \\
\text { making and activities. }\end{array}$ \\
\hline $\begin{array}{l}\text { Contribution / influence towards } \\
\text { building national health services/ } \\
\text { system (notion of "giving back"). }\end{array}$ & $\begin{array}{l}\text { Contribution / influence towards } \\
\text { building national health services/ } \\
\text { system (notion of "giving back"). }\end{array}$ \\
\hline \multirow{2}{*}{ student activities in communities. } \\
\cline { 2 - 2 } & $\begin{array}{l}\text { Faculty preparation, understanding } \\
\text { of CBE and their practices. }\end{array}$ \\
\hline
\end{tabular}

\section{Setting and Participants:}

Considering that various tiers of leadership and individuals are involved in academic decision-making in HPE institutions, for the study we included a purposive sample of Academic Heads (AHs) - deans /principals of HPE 
institutes (medical and nursing colleges) and heads of community departments (HODs). In medical colleges of Pakistan, deans/ principals hold general leadership and decision-making responsibility for the whole institution. Broadly speaking, they have authority over decisions pertaining to institutional strategy, reward structures, policies and approval for resource allocation. Curricular planning, recruitment of faculty and ensuring their continuous education is the responsibility of departmental heads. In nursing colleges, there are no individualized departments or departmental heads, AHs are solely responsible for all academic management and decisions. Hence data were collected from AHs of nursing colleges, and from AHs and HODs of medical colleges.

List of recognized colleges of medicine and nursing were obtained from their respective councils, all those HPE institutes were shortlisted where undergraduate programs for both professions -medicine and nursing were present, there are 15 such HPE institutes, hence a total population of 30 colleges. First contact to the college was made through phone call, at this stage, four colleges dropped due to wrong or outdated phone number. In the remaining 26 colleges, separate phone calls were made to the deans/principals of medical and nursing colleges and HODs of community medicine department. Being mindful of our participants' busy schedules, we made a follow up call after initial waiting of two weeks from the date the survey was emailed and then two times more, each call one week apart. Finally, we received response from thirteen individuals (7AHs and 6 HODs), who represented major HPE institutes and were in position to 
provide an overall picture of the CBE scenario in Pakistan, and whose responses were analyzed and are presented here.

\section{RESULTS}

\section{Respondent's characteristics:}

The respondents represented a mix of heads from seven public and private HPE institutes where undergraduate programs for both professions -medicine and nursing- are present, from the four major cities of Pakistan: Karachi (02), Islamabad (02), Lahore (01) and Peshawar (02). The AHs were mostly -90 percent males, having an average job experience of nine years as deans or principals. All the HODs were females with an average two years of experience in their current position.

The perceptions of respondents and their institutional structures towards CBE were analyzed around the functions of Teaching and learning, Research, and Service to the community:

Appreciation and satisfaction with the implementation of CBE: 8 out of 13 respondents identified $\mathrm{CBE}$ as part of their institutional strategy, they further perceive that their curriculum design encourages faculty and students to practice in community settings and that $\mathrm{CBE}$ is implemented from some to full extent in their institution. Simultaneously, all respondents shared their dissatisfaction over implementation of CBE in other HPE institutes of the country. Out of 13 respondents, 9 identified lack of role models; 2 believe financial constraints, and 2 consider lack of quantitative evidence about CBE in improving health of population as 
important challenges and reasons for CBE not fully implemented in the country.

\section{Faculty preparation and practices:}

The average number of faculty in community medicine departments is 6 . The maximum was 12 in one institute for a class of 100 students, about half of these faculty members have received formal training in public health. With respect to the activities the faculty performs when they are in community field sites, HODs shared that most frequent $(80-100 \%$ of time) faculty's activities include supervision of students at the clinic (while they are consulting patients) or consulting patients themselves. Occasionally to rarely (10-20\% of time) they carry out community based researches; plan \& implement community projects \&/or assessment, and participate in community meetings. The average time a faculty spends at the field site is around $30 \%$ of their total time in the college. Experiences which HODs consider that their faculty members have initiated to improve health outcomes of the population include initiation of health education programs through students and managing health centers at the field site. The perceptions of HODS about expertise of faculty members in various functions concerning CBE is that they are competent to a great extent for classroom-based teaching and are fairly competent in teaching at the field site. In their understanding about issues of CBE and community health the HODs perceived their faculty to be somewhat competent and not competent to write grants, carry out community-based research and community-based assessments. Two HODs identified promotion of critical 
thinking and planning skills as important development needs for their faculty.

\section{Student activities in communities:}

For students, two respondents reported to have structures in place to encourage work in community settings, while in the remaining institutions there are few to no structures to facilitate community based activities and practices for students. The most frequently performed activities by students include health education and individual consultation of patients at the clinic. Occasionally they carry out a small project and organize health education sessions for groups of a number of families. They seldom get engaged with mass level screening or immunization, or involve community members in their projects.

\section{Reward and support structures:}

Most AHs consider teaching to be the most important factor in promotion criteria, followed by publications. Service to the community or research in the field and acquiring grants were not mentioned as important promotion criteria. However, faculty members' service in the community is recognized through offering extra points towards promotion or by financing them to attend conferences.

To keep abreast with the developments in community health and CBE, faculty development activities consist of attending and presenting in conferences and workshops and at a few places departmental journal' clubs are part of ongoing education. Interestingly, none of the community 
departments within medical colleges have subscriptions to CBE / community health related journals. The introduction of a faculty incentive model is one on the wish lists of AHs.

\section{Research:}

In only three institutions out of seven from our sample, 5-10\% of researches are concerned with the health issues prevalent in their respective community populations. Out of the total community related researches, half are carried out in collaboration with external agencies of which a further half are partnered with the local communities and the remaining with international agencies. None of the researches are partnered with local or national health departments.

\section{Community support and development:}

Few institutions partnered with local community representatives for the selection of field sites. The involvement of most respondents at national and international level activities is restricted to participation in conferences or at health meetings. Rarely any input in the development of national or international health policies or programs was reported.

\section{Propositions:}

The suggestions coming from Academic and Department Heads for enhancing CBE focused only on the curriculum, not on the broader institutional structures; some examples they gave include adding prevalent community health problems in student assessment; the rationalization of the curriculum to suit the needs of the community; 
matching curricular content with current global trends, and clinical training to be integrated within community rotations.

\section{DISCUSSION}

Our exploratory findings suggest that the academic leaders consider their institutional mission and strategies aligned with the broader HPE mission i.e. preparing effective graduates, providing high quality care to the communities they serve, and advancing knowledge through research. The practices, experiences and recommendations as shared by academic leaders evidently indicate that their belief of community service and their notion of contribution are not translated into their institutional practices, policies and priorities. We found that there is a dissonance between opinions \& beliefs with the practice of faculty, and policies of institutions as communicated by academic heads. In a number of responses we have found that faculty practices, student activities and research are not aligned with the overall mission of HPE or goals of CBE. Faculty and student activities at the community field sites are limited to consult

patients or, at most, carry out health teaching sessions ${ }^{[6,9]}$. Community research is not common, and where a few researches are done these are in isolation.

With respect to the reward structures and promotion criteria, one of the interesting finding is that teaching is considered more important than publication in the promotion criteria; and the other two criteria namely community service and community based researches are found to be on the lower side and not a priority concern of the institutes. This finding is in conformity with a number of other studies ${ }^{[3,6,13,14,24]}$; except for the fact 
that in academia there seems to be a general agreement that teaching is undervalued, research is overvalued, and service is the least valued ${ }^{[24-26]}$ Diane and colleagues suggested that faculty are more likely to receive promotion for publishing articles in peer-reviewed journals than for demonstrating an active commitment to addressing community problems. They further added that well aligned university's mission and reward structures and emphasis on community service and civic engagement encourages faculty to value community service and helps them sustain their involvement in communities ${ }^{[13]}$.

We also found that, there aren't too many faculty development activities targeted towards managing perceptions and creating an academic culture conducive to CBE. The current definitions of faculty development are emphasizing change in attitudes along with knowledge and skills, extending its reach from the individual learner to the entire educational system, and encompassing the whole spectrum of teaching, which is particularly pertinent to the approaches such as CBE and competency model ${ }^{[26-29]}$. Another critical finding in this realm is that faculty development activities are limited to workshops or seminars only, while scientific journals on CBE are hardly available. There are a number of other effective faculty education methods such as short courses, fellowships, peer coaching, mentorship, self-directed learning, computeraided instructions which HPE institutes must recognize and employ to not only improve practice and manage change among faculty members but also to enhance organizational capacities, infrastructure and culture, similar to what was earlier emphasized ${ }^{[3,28,29]}$. 
Lack of role models has been identified as one of the major impediments in the implementation of $\mathrm{CBE}{ }^{[30}{ }^{31}$. Role modeling is often an unconscious process, and some of the powerful role modeling tools in HPE is the personal approach of teachers such as showing enthusiasm, commitment and passion, being competent, etc. ${ }^{[30,31]}$. We found that a number of faculty members only visit community sites to supervise students and have limited roles for themselves in the field. This goes true for AHs also who are not frequent contributors towards community development in general and healthcare of local communities in particular. It is expected from academic leaders to set the direction, influence the decisions and identify the challenges the institution is facing to achieve their mission. In addition, they are responsible for creating an organizational culture which stands out as one of the important components that leaders can employ to sustain performance. What institutional leadership emphasizes and measures overtime shapes the organization's culture, provides benchmarks for faculty members and all other staff that ultimately inspires students and affect their performance. What and where the attention is placed upon belongs to the most powerful indicators of how leaders and organizational founders communicate values, beliefs and priorities [19 -24]. Despite obvious limitations due to a small sample size, we could see a common and consistent thread among all responses that the idea about community service and the notion of purpose and contribution, which the academic leaders consider as important, are insufficiently translated or reflected 
into what they described as their institutional practices, policies, priorities and structures.

\section{LIMITATIONS}

Our sample size was small due to two important factors; to begin with, the HPE institutes offering both medical and nursing undergraduate programs are relatively fewer in Pakistan. Secondly, we were seeking organizational information from individual executives, which typically receive substantially lower return rates ${ }^{[32-34]}$. Nonetheless, as all our respondents were coming from major HPE institutes and were fully responsible for all academic management and decisions in their respective institutions, we believe the findings do provide an overall picture of the CBE scenario in Pakistan. Moreover, the study has generated a number of hypotheses that can be empirically tested in future researches.

\section{CONCLUSION}

There are no valid instruments available in the field of HPE to examine institutional culture toward $\mathrm{CBE}$; the aspects that were examined using the self designed tool provided a sketch of CBE culture in HPE institutes of Pakistan. The study identified that academic leaders have contributed to move CBE agenda in their institutes; its timely and necessary now to move on the next level, that is to reflect on ways that can help develop such academic leadership which is ready to bring a paradigm shift - a "culture" of giving back to societies, serving the communities and populations, teaching, learning and researches that are focusing on the health care 
needs of local communities and involving community representatives in HPE decision making.

\section{REFERENCES}

1. Hecker K. Medical School Curricula: Do Curricular Approaches Affect Competence in Medicine?

Family Med 2009; 41(6):420-6.

2. Morahan P.S. Gold J.S. Bickel J. Status of faculty affairs and faculty development offices in U.S. medical schools. Acad Med 2002; 77(5):398-401

3. Bloom S.W. Structure and Ideology in Medical Education: An analysis of resistance to change. Journal of Health and Social Behaviour. 1988; 29: 294-306

4. Hafferty F. W. Beyond Curriculum Reform: Confronting Medicine's Hidden Curriculum Acad. Med. 1998;73:403-407.

5. Lubna B. A. Akram D.S. Ali S.K. Development of the CommunityOriented Medical Education Curriculum of Pakistan: A Case Report on the national initiative on curriculum development. Education for Health. 2006; 19: $223-228$.

6. Ladhani Z. Scherpbier A.J. Stevens F.J. Competencies for Undergraduate Community Based Education for the Health Professions - A Systematic Review. Medical Teacher. 2012; 39 (9): 733-743

7. Hays R. Community-oriented medical education. Teaching and Teacher Education. 2007; 23: 286-293.

8. Kristina T.N. Majoor G.D. Van Der Vleuten. Does Community-Based Education come close to what it should be? A Case Study from the developing world: students' opinions. Education for Health. 2006; 19: $179-188$.

9. Kristina T.N. Majoor G.D. Van Der Vleuten. Does Community-Based Education come close to what it should be? A Case Study from the developing world: evaluating a program in action against objectives on paper. Education for Health. 2005; 189:208.

10. Frenk, J. Chen L. Bhutta Z.A. et al. Health professionals for a new century: transforming education to strengthen health systems in an 
interdependent world. www.thelancet.com. 2010 November 29; doi:10.1016/S0140-6736(10)61854-5

11. Bikmoradi A. Exploring academic leadership in medical schools and universities in Iran: A report. (2009). Medical Management Centre, Department of learning, informatics, Management and Ethics. Karolinska Institute, Stockholm, Sweden

12. Alice A.K. \& Stuart J.S. Community-based education: is the effort worth it. Medical Education. 2001; 35:315 \pm 316 .

13. Diane C. Jordon C. Sarena D. S. Community-engaged scholarship: Is faculty working communities a true academic enterprise? Academic Med. 2005; 80: 317-21.

14. Linda P. David E. K. Phyllis C. Peter C. Sharon K. The Culture of Academic Medicine: Faculty perceptions of the lack of alignment between individual and institutional values. J Gen Intern Med. 2009 Dec; 24(12):1289-95 doi: 10.1007/s11606-009-1131-5.

15. Kathleen M. B. Assessing Pre-service Leaders' Beliefs, Attitudes, and Values Regarding Issues of Diversity, Social Justice, and Equity: A Review of Existing Measures, Equity \& Excellence in Education. 2004; 37:4, 332-342. http://dx.doi.org/10.1080/10665680490518948.

16. House R.J. A path goal theory of leader effectiveness. Administrative Science Quarterly, 1971; 16(3). 321 - 339.

17. Taylor W. E. The logic of global business: An interview with ABB's Percy Barnevik. Harvard Business Review. 1991; 69(2): 93-105.

18. Schein E. Organizational culture. American Psychologist. 1990; 45, 2: 109-119

19. Shein E. (1992). Organizational Culture and Leadership: A Dynamic View. San Francisco, CA: Jossey-Bass. p. 9.

20. Ravasi D. \& Schultz M. (2006), "Responding to organizational identity threats: exploring the role of organizational culture", Academy of Management Journal, Vol.49, No.3, pp. 433-458.

21. Cox B. E. \& McIntosh K.L. Reason R.D. \&Terenzini P. A Culture of Teaching: Policy, Perception, and Practice in Higher Education. Research in Higher Education .2011; 52: 808 - 829

22. Tsai Y. Relationship between Organizational Culture, Leadership Behavior and Job Satisfaction BMC Health Services Research. 2011, 11:98 doi:10.1186/1472-696311-98. 
23. Casida J. Pinto-Zipp G. Leadership-organizational culture relationship in nursing units of acute care hospitals.

NursingEconomic 2008, 26(1):7-15

24. Joyce S. Joanne R. Perceptions of tenured nursing faculty related to decision-making for community service. Nursing Outlook. 2007; 55:202-207

25. Bravaro J.A. A review of the construct of scholarship in the literature. Educational Resources Information Center (ERIC). U.S. Department of Education 1995; 1-38.

26. Colbeck C.L. Integration: Evaluating faculty work as a whole. New Directions for Institutional Research 2002; 43-52.

27. Dath D. \&Lobst W. The importance of faculty development in the transition to competency-based medical education. Medical Teacher. 2010; 32: 683-686.

28. Steinert Y. Mann K. Centeno A. Dolmans D. Spencer J. Gelula M. Prideaux D. A systematic review of faculty development initiatives designed to improve teaching effectiveness in medical education: BEME Guide No. 8. Medical Teacher. 2006; 28(6):497-526.

29. Steinert Y. Mann K.V. Faculty development: Principles and practices. J Vet Med Education. 2006; 33(3):317-324.

30. ReulerJ. B. \&NardoneD. A. Role modelling in medical education. West J Med. 1994 April; 160(4): 335-337.

31. Hutchinson L. ABC of learning and teaching in medicine: Educational environment.BMJ 2003; 326:810-812.

32. Hager M.A. et al. Response Rates for Mail Surveys of Non-profit Organizations: A Review and Empirical Test. Nonprofit and Voluntary Sector Quarterly, vol. 32, no. 2, June 2003 252-267

33. Baldauf A. Reisinger H.\&Moncrief W. C. (1999). Examining motivations to refuse in industrial mail surveys. Journal of the Market Research Society, 41, 345-353.

34. Tomaskovic-Devey D. Leiter J. \& Thompson S. (1994). Organizational survey non-response.

Administrative Science Quarterly, 39, 439-457. 
Chapter 6

General Discussion 


\section{DISCUSSION}

Health Professions' Education (HPE) is a dynamic process and should take place within a local context which must be determined based on the health care needs of the local population. Physicians and nurses need to be competent to respond to the needs of the populations they serve, and improve access to health care especially through reaching out to remote and poor communities who otherwise have no means to access health care. Community Based Education ( $\mathrm{CBE}$ ) is recognized as a means to achieve educational relevance to community needs and its learning activities requires extensive utilization of the community field sites ${ }^{[1]}$.

The overall goal of CBE which is to improve universal access of basic health care is still not realized, as everywhere there remains pockets of vulnerable populations without access to health care and availability of competent health professionals to work in community settings is an acute and complicated issue ${ }^{[2-5]}$. Problems with health systems and poor working conditions in remote and rural areas poses significant threats that keep health professionals from opting to work in community setting [4- 7]; however health systems obstacles represent only one side of the coin, the other side concerns with HPE and preparation of health professionals. In recognition of the problems within HPE, this thesis examined CBE from the perspectives of health professionals practicing in the community setting, faculty who teach and supervise students in their community rotations, academic heads who are responsible to make decisions and harness culture of the institution. The thesis has also reviewed literature to identify what is known about competencies that 
best fit for community based education, and identified gaps in the published literature and practice at the HPE institutes of Pakistan. The basic research questions investigated in this thesis were broadly framed as: Is CBE implemented in its true spirits in the HPE institutes? What are the opportunities and challenges for implantation of CBE? Is competency approach a better curricular strategy for CBE? In the following paragraphs, we have summarized and synthesized the key findings from our studies, share its strengths and limitations, and have considered their implications for future research and policy development.

This chapter presents the findings and conclusions emerged from our research studies on CBE and how curriculum, faculty members, and academic leaders affect the learning and career choice of HP students and ultimately health care of population.

\section{SUMMARY OF RESEARCH FINDINGS}

\section{CBE Competencies in literature:}

Through a systematic review (Chapter2) aimed at identifying and categorizing CBE competencies implemented in nursing and medical schools and documented in peer reviewed journals, we found only 19 research articles which have explicitly identified competencies for CBE. We categorized these competences into six broad themes namely: Public Health, Leadership \& Management, Advocacy \& Community Development, Research \& Evidence Based Practice and Cultural and Generic. The articles extracted are not only limited in numbers but also lacks representation of developing nations. The results supported our 
assumption that not many places have developed competency approaches for CBE and competency models documented in HPE literature mainly focuses on preparing physicians and nurses to treat diseases and for providing care to sick at secondary and tertiary levels.

\section{CBE competencies in practice:}

Using the categories of CBE competencies, our next study (chapter3) investigated practice of physicians and nurses working in community settings and also explored potential variations in competencies between different settings and employers - government, NGOs, and university run health facilities. The aim of this study was to find out whether these competencies are identifiable in the practice at community settings, whether these are affected by impeding factors and whether these are recognised by various stakeholders including the health professionals themselves. The results of the study provided insight into some critical facts. Firstly, the current generation of health professionals are not well prepared by education and training to provide comprehensive care to the general population. Secondly, in community settings there are many synergies between the competencies of physicians and nurses. At the same time these two groups offer distinct sets of services, which at present are not harnessed to build effective, non-hierarchal, collaborative health teams. Finally, there are a number of factors concerning the health system -such as poor work environment, lack of clear roles and job descriptions, fewer opportunities for continuous education and professional development- that have negative effect on the practice of 
health professionals which could only be improved through strong collaboration between academicians and policymakers.

\section{CBE competencies in HPE institutes:}

The most critical challenges that CBE and/ or competency approach faces within HPE institutes concerns either with the structure: faculty practices and curriculum (chapter 4) or culture: values, polices and leadership (chapter 5).

Among the faculty members who are entrusted with the delivery of $\mathrm{CBE}$, we found two common problems: the first one is related to faculty members' grounding of CBE concepts (chapter 4). There are many who are not properly prepared; while their views on CBE are limited and they consider lectures and field trips as adequate methods for preparing graduates for practice in community settings. Second, there is a lack of commitment and to a certain degree resistance to change. There are faculty who are not fully committed to or believe in CBE; they know of various CBE models and case studies, but their practice does not support that awareness. They seem not to have internalised the real meaning of $\mathrm{CBE}$, with many concepts and competencies remaining to them nothing more than empty labels without true substance. Unless comprehensive faculty development programs aimed at holistic change are introduced in HPE institutes, one would continue to find temporary and superficial adjustments without real impact on practice of faculty, students' learning or health of communities.

Similar kinds of issues were also present at the leadership level (chapter5). Our exploration into practices and experiences as shared by 
academic leaders evidently indicate that their belief of community service and their notion of contribution are not effectively translated into their institutional practices, policies and priorities. Teaching and publication is generally considered important functions of faculty members and are the top two criteria for promotion and budgetary allocation whereas community service and community based researches are found to be on the lower side and not a priority concern of the institutes. In addition, lack of community oriented role models are also identified as impediment in the implementation of CBE. The issue identified by us and by other

researches ${ }^{[8-10]}$ can be overcome through managing perceptions and for creating an academic culture conducive to CBE.

\section{STRENGHTS}

\section{Subject matter:}

The questions and topics researched as part of the thesis are critical and important for HPE as well as for the larger context of health care system in several ways. First, the topics that we have concentrated on are important elements concerning CBE which were not studied in-depth before, not at least in Pakistan such as CBE competencies, perceptions and practices of faculty members and academic leadership. Secondly, the thesis has identified some critical gaps in the existing literature such as our chapter 2 which was a systematic review have identified that CBE specific competencies are not well represented in HPE literature. Likewise, chapters 4 and 5 have indicated a dearth of literature on leadership, institutional culture and values $\&$ beliefs systems specific to 
the discipline of HPE. Finally, findings of our research studies have not only added to the existing knowledge but also have highlighted practical implication for proper recognition and integration of CBE within HPE and in the health systems.

\section{Methodology:}

A variety of methods were employed to test the assumptions and answer research questions of the thesis such as use of focus group discussion, indepth interviews, review of documents (job description) and web based questionnaires. The diverse methods and tools also allowed us to validate the results both within and between chapters and studies.

\section{Participants:}

The research participants of our studies were diverse and represented different cadres of workers within and outside HPE institutes, for example we for our initial study, the participants were HPE graduates and their employers from there on, for our next studies we included faculty members and then head of departments and finally head of institutions, thus through our studies we explored all key players involved with HPE directly or indirectly.

\section{LIMITATIONS}

A limitation of this thesis is that many of the studies were conducted within the setting of the undergraduate medical and nursing programs in Pakistan only. Even though it may have limited the scope of its generalizability to some extent, we believe that the issues addressed in these

studies and the thesis is common and pertinent to CBE situation 
elsewhere too especially to countries with similar socio economic and geo-political makeup. Moreover, most of our results are also applicable to other settings because many of the research findings are supported by earlier publications on CBE from around the world ${ }^{[10-17]}$.

Secondly, we have studied programs, competencies, challenges and strengths of physicians and nurses side by side which may have presented a somewhat confusing picture and may have given out a false impression that we were trying to overlap these two distinct professions. While we recognize that the competencies, roles and expectations for each of these health professionals vary considerably, it is also critical to espouse the interdisciplinary nature of $\mathrm{CBE}$, particularly in resource poor countries where usually there is an overlap in the roles of health professionals as a means for improving access and providing comprehensive and continuous care to underserved populations. Hence recognizing the significant implications for the education and training of future health professionals who must be prepared to provide full spectrum of care including roles of other providers also, we included two health professions in our thesis.

\section{FUTURE RESEARCH IMPLICATIONS}

A number of important areas for further research have been identified in this thesis. There are certain topics which need to be further tested empirically, these topics are elaborated here:

\section{Competency approach for CBE:}

Through systematic review, we have identified and categorized a number of specific competencies (Chapter 2) which through further research must 
be validated and tested in various health care scenarios and practice settings. Research is also needed on how CBE competencies are perceived by faculty members, students and communities; how to assess competencies in community settings and more importantly, future research should quantitatively examine the impact of the competency approach in CBE on graduates' career choice and practice.

\section{Institutional culture:}

One of our research studies (Chapter 5) has identified the need for empirical investigation into academic leadership especially the top executives' impact on the culture of the institution and values and belief systems of individuals in the institution. There is also a need to enrich these investigations by qualitatively exploring how and why a dean's or principal's leadership behavior, if at all, affects institution's prevalent cultural values. Yet another interesting area for further research would be to explore what kind of culture in HPE institutes promote community orientation among its faculty and students, and to examine the role of academic leadership in harnessing institutional culture in support of community needs. These research topics are important because, firstly, there are hardly any empirical studies in HPE and, secondly, in business models there are conflicting evidences. On the one hand there is evidence that leadership does impact performance ${ }^{[18-24]}$, while on the other hand a number of researches have also indicated that in many situations leaders'

actions produce no difference in organizational performance ${ }^{[25-28]}$. Therefore it is essential that this construct be studied in depth. 


\section{FUTURE HPE and POLICY IMPLICATIONS}

Throughout the thesis and within individual chapters we have discussed a number of general implications, some of which suggest reforms within HPE - such as revisiting its priorities, policies, reward structures, curricula and methods of teaching/ learning, while other propositions stipulate going beyond HPE institutions to support health systems and policies. There are a number of contextual evidences ${ }^{[3-6]}$ including our own research that have identified that difficult working conditions in remote /rural areas - poor systems \& structures, lack of resources, safety concerns, being alone without professional support or advice, no one to 'check' on them, social isolation - affects the career choice and performance of HPs. Thus HPE and Health systems HPE are inseparable and HPE reforms would not be complete without restructuring the health systems and vice versa. In addition to the aforementioned implications, we still would like to elaborate on few additional specific recommendations:

\section{Leadership development:}

Although we have already discussed in detail the implications of leadership development for sustainable and effective change towards $\mathrm{CBE}$, we would like to further emphasise this point. HPE institutes should strive to develop academic leadership if it wants to engage leadership and faculty to respond effectively to complex health care and health education concerns. For an effective change of culture, research suggests such a leadership which is capable of providing a vision and direction to HPE institutes across all health professional school ${ }^{[21,29]}$. We recommend 
a leadership program to be implemented in two phases: on immediate basis a program to develop young leadership which can take forward the agenda of change; and for a long term, a reform in academic leadership including structural (policies, governance and stewardship); cultural (norms, routine and values), managerial (rules and regulations) and relationship building within circles of HPE institutes, outside with health systems and health care providers, policy makers and community representatives.

\section{Comprehensive faculty development programs:}

We found a number of challenges pertaining to faculty development; while some institutions do not allocate resources for faculty development programs, others have diluted training sessions which focus only on knowledge domain, and the methods used are often outdated or limited [30-32]. The current literature demonstrates an over-reliance on traditional methods for teachers training such as workshops and seminars. While these methods seem to be highly prevalent in HPE institutions for practical reasons, given the sensitive nature of $\mathrm{CBE}$ and complexity of introducing it with the competency approach, we recommend other methods of teaching that encompass cognitive and affective domains also such as experiential learning opportunities, on-going peer coaching and mentorship as well as self-directed learning ${ }^{[31-33]}$ as these would help to build a community of interested educators with heightened motivation and increased level of competence.

Moreover, our researches have signify that faculty development programs needs to be comprehensive with the aim of preparing faculty members as 
role models, who are able to encourage and bring about attitudinal change in students and other stakeholders, such as institutional administrators, community representatives and policy makers. These programs may include aspects ranging from instructional development, leadership development and organizational development for orienting new faculty members as well as are built into the continuous education programs [30]. Such programs are not only fundamental for academic vitality but also necessary for integration of concepts like CBE and competencies into HPE as Mahler puts it: "The development of health personnel able and willing to serve communities by providing health care, promoting health, preventing disease and caring for those in need is a major and formidable task of educators. It is they who have the responsibility of ensuring that training programs are relevant to present and future community requirements as well as to the characteristics of learners, and that the programs are effective and efficient in maximizing the potential of each student to acquire the competencies and attitude needed to carry out his or her tasks as a member of health care team" (Mahler in the preface of WHO report -34].

\section{Role and career path for Community Health nursing:}

From one of our studies on practice of health professionals (Chapter 2), we found a huge gap in the availability of Registered Nurses (RNs) in the community care settings. There are very few RNs employed in community settings $[35,36]$ and no official data is available on the number of community health nurses (CHNs). As the author herself has worked for a few years as a Community Health Nurse in Pakistan, the personal contacts 
informed that at present out of 52,000 RNs registered with council ${ }^{[37]}$ (no data is available on the exact number of nurses currently in the workforce), only thirty to forty work as Community Health Nurses (CHNs). The gravity of this problem could further be elucidated by the fact that in the public sector there is no designated position or career structure for RNs in community settings, although a recent pilot programme ${ }^{[38]}$ has introduced the position of staff nurse at the secondary level of community care in ten districts (out of 136). However the long term sustainability of the program and the staff employed is a big question. Our research has clearly identified an urgent need for clearly defined roles and career paths for nurses in community setting in Pakistan, which can be reflected in their curriculum.

\section{CONCLUSION}

For HPE programs to be capable of producing community oriented health professionals who are available to improve access to health care, who are competent to improve the health outcomes of the population and who could avert the current health care challenges of society, our research studies and thesis have arrived to following conclusive remarks and recommendations:

\section{Integration of CBE in its true sense:}

We found that changes in the name of CBE mainly represent content addition in the HPE curriculum which is expected to be "covered" by "community medicine department". For a strategic and sustainable change, the reforms within HPE institutes must be conceived and 
delivered in a well balanced manner. The reorganization must aim at improving, stabilizing and aligning all its elements- institutional culture, structure, policies, curriculum, teaching methods, research priorities, faculty and leadership - for community as well as hospital settings. That, these reforms must surround all levels of care -primary, secondary and tertiary - in a holistic and integrative fashion for promotion of health, prevention and treatment of disease and rehabilitation.

\section{Harness synergies between health professionals:}

Our thesis also indicated that in community settings there are many synergies between the competencies of physicians and nurses. At the same time these two groups offer distinct sets of services, which should be harnessed to build effective, non-hierarchal, collaborative healthcare teams. Recent literature has a lot to offer on how to effectively mobilize services of health professionals by incorporating an integrative health perspective into health professions education and a workforce planning, deployment, and utilization, thus creating a better integrated health care system.

\section{Partnerships between academicians, policymakers and communities:}

Finally, as mentioned a number of times in the thesis that HPE or CBE for that matter cannot be delivered in a vacuum, it is affected by the society and by its prevalent systems. Presently, HPE is working in its own silo; curriculum planning and delivery is solely carried out within the institutes, researches are hardly partnered and contributions by its faculty or graduates are limited ${ }^{[39-42]}$. For the transformation in its values, beliefs, 
practices and policies, one valuable action would be to go beyond the walls of HPE and embrace meaningful partnerships with other stakeholders - health sector policy makers, other socio-economic sectors that influence health and community representatives- to bring the change within HPE. Thus, in the change process, the health care delivery system should also be considered.

\section{REFERENCES}

1. Menin S. Menin R. Community Based Medical Education. The Clinical Teacher. 2006; 3: 90-96

2. Iliffe $\mathrm{S}$. All that is solid melts into air -the implications of community based undergraduate medical education. British Journal of General Practice. 1992; 42, 390-393.

3. Durso S. C. Form Follows Function: Moving Medical Education into the Community. Virtual Mentor. 2005; 7 (6).

4. Kinfu Y. Dal Poz M.R. Mercer H. \& Evans D.B. The health worker shortage in Africa: are enough physicians and nurses being trained? Bulletin of the World Health Organization 2009;87:225230. doi: 10.2471/BLT.08.051599

5. Naicker S. Plange-Rhule J. Tutt R.C. Eastwood J. B. Shortage of healthcare workers in developing countries-Africa. Ethn Dis. 2009; 19(1 Suppl 1):S1-60-4.

6. Mareck D.G. Federal and State Initiatives to Recruit Physicians to Rural Areas. Virtual Mentor. 2011; 13 ( 5 ): 304-309.

7. Chaudhury N. \& Hammer J.S. Ghost Doctors: absenteeism in rural Bangladeshi health facilities. The World Back Economic review. 2004; 18 (3): 423-441

8. Diane C, Jordon C, Sarena D S. Community-engaged scholarship: Is faculty working communities a true academic enterprise? Academic Med. 2005; 80: 317-21.

9. Linda P. David E. K, Phyllis C, Peter C, Sharon K. The Culture of Academic Medicine: Faculty perceptions of the lack of alignment 
between individual and institutional values. J Gen Internal Medicine. 24(12):1289-95 doi: 10.1007/s11606-009-1131-5.

1. Kathleen M. Brown (2004): Assessing Pre-service Leaders' Beliefs, Attitudes, and Values Regarding Issues of Diversity, Social Justice, and Equity: A Review of Existing Measures, Equity \& Excellence in Education, 37:4, 332-342. http://dx.doi.org/10.1080/10665680490518948

2. Mullan F. Chen C. Petterson S. Kolsky G. Spagnola M. The Social Mission of Medical Education: Ranking the Schools. Ann Intern Med. 2010; 152: 804-811.

3. Larry W.C. et al. Perceptions and valuation of a CommunityBased Education and Service (COBES) program in Uganda. Medical Teacher. 2011; 33: e9-e15.

4. Kristina T.N. Majoor G.D.Van Der Vleuten. Does CommunityBased Education come close to what it should be? A Case Study from the developing world: students' opinions. Education for Health. 2006; 19: $179-188$.

5. Kristina T.N. Majoor G.D. Van Der Vleuten. Does CommunityBased Education come close to what it should be? A Case Study from the developing world: evaluating a program in action against objectives on paper. Education for Health. 2005; 189:208.

6. Frances M. O. Yoshimoto C. M. Bell S.\&Nuinos R. Educating health professionals in a community setting: What students' value. Education for Health. 2001; 14(2), $256-266$.

7. Tyler I. V. \& et al. Canadian Medical Students' Perceptions of Public Health Education in the undergraduate Medical Curriculum. Academic Medicine, 2009; 84 (9): 1307 - 13129

8. Bloom S.W. Structure and Ideology in Medical Education: An analysis of resistance to change. Journal of Health and Social Behaviour. 1988; 29: 294-306.

9. Rosenblatt R. A. Commentary: Do Medical Schools Have a Responsibility to Train Physicians to Meet the Needs of the Public? The Case of Persistent Rural Physician Shortages.Acad Med. 2010; 85:572-574.

10. Wisniewski M.A. Leadership in higher education. Implications for leadership development program. Academic leadership, the online journal. 2007; 1-13 
11. Day D.V. Leadership development. A review in context. Leadership Quarterly. 2000; 11: 581-613

12. Dill D.D. The management of academic culture: notes on the management of meaning and social integration. Higher Education. 1982; 11, 303-320

13. Bikmoradi A. Exploring academic leadership in medical schools and universities in Iran: A report. (2009). Medical Management Centre, Department of learning, informatics, Management and Ethics. Karolinska Institute, Stockholm, Sweden

14. Shein E. (1992). Organizational Culture and Leadership: A Dynamic View. San Francisco, CA: Jossey-Bass. p. 9.

15. Tsai Y. Relationship between Organizational Culture, Leadership Behavior and Job Satisfaction. BMC Health Services Research. 2011; 11: 98 doi:10.1186/1472-6963-11-98.

16. Casida J. Pinto-Zipp G. Leadership-organizational culture relationship in nursing units of acute care hospitals. NursingEconomic 2008; 26(1):7-15

17. Waldman D. A. Ramirez G. G. House R. J. \&Puranam P. Does leadership matter? CEO leadership attributes and profitability under conditions of perceived environmental uncertainty. Academy of Management Journal. 2001; 44: 134- 143.

18. Howell J. P. \& Dorfman P. W. Substitutes for leadership: Test of a construct. Academy of Management Journal. 1981; 24:714- 728.

19. Pettigrew A. M. On studying organizational cultures. AdministrativeScienceQuarterly. 1979; 24: 570 -581.

20. Pfeffer J. The ambiguity of leadership. Academy of Management Review. 1977; 2: 104- 112.

21. Kimberly J. R. Preparing Leaders in Public Health for Success in a Flatter, More Distributed and Collaborative World Public Health Reviews. 2011; 33:289-99.

22. Steinert Y, Mann K, Centeno A, Dolmans D, Spencer J, Gelula M, Prideaux D. A systematic review of faculty development initiatives designed to improve teaching effectiveness in medical education: BEME Guide No. 8. Medical Teacher. 2006; 28(6): 497-526.

23. Flynn S.P. Bedinghaus J. Snyder C. \& Hekelman F. Peer coaching in clinical teaching: a case report. Educational Research and Methods, 1994; 26(9), pp. 569-570. 
24. Morzinski J.A. Diehr S. Bower D.J. \& Simpson D.E. A descriptive, cross-sectional study of formal mentoring for faculty. Family Medicine. 1996; 28(6), pp. 434-438.

25. Bligh J. Faculty development. Medical Education. 2005; 39, (2): 120-121.

26. F. M. Katz and T. Fülöp: editors. Personnel for health care: case studies of education programs. Public health papers 70 , Vol 1. Geneva: World Health Organization 1978. http://apps.who.int/iris/bitstream/10665/39452/1/WHO PHP 70

27. Gulzar, S.A. Shamim, M.S., Khuwaja, A.K. Promoting motivation towards community health care: A qualitative study from nurses in Pakistan. J Pak Med Assoc. 2010; 60 (6): 501-503.

28. Ladhani Z. Developing competencies for a community-based nursing curriculum. Medical Education. 2009; 43: 471-499. doi: 10.1111/j.1365-2923.2009.03324.x

29. Official Web site of Pakistan nursing council : [http://www.pnc.org.pk/Registration.htm]

30. Minimum service delivery standards for primary and secondary health care in Punjab: Report. Accessed on April $22^{\text {nd }} 2013$. http://www.pdssp.gop.pk/downloads/documents/MSD Health Final.pdf

31. Boelen $C$. The challenge of changing medical education and Medical Practice. World Health Forum. 1993; 14: 214- 216.

32. Bryant J.H. Educating Tomorrow's Doctors. World Health Forum. 1993; Vol 14: 216- 230.

33. Showstack J. et al. Health of the public: the academic response. Journal of the American Medical Association. 1992; 267: 2497 2502.

34. Topps M \& Strasser R. When a community hospital becomes an academic health centre. Can J Rural Med 2010; 15 (1). 
Chapter 7

\section{Summary}




\section{CHAPTER 1: GENERAL INTRODUCTION}

This thesis concerns Community Based Education (CBE) within the undergraduate medical and nursing programs. Most literature on CBE describes its characteristics, goals and purpose or lately evaluation of various CBE models have started to emerge in the literature. However, there is little insight into the process of integrating $C B E$ in the larger context of HPE or about the professional competencies required to effectively practice in community settings. The thesis has examined institutional structures, perspectives and practices on CBE in HPE institutes and professional competence of HP graduates working in community settings of Pakistan.

CBE is an HPE approach that focuses on groups and individuals, taking into account the health needs of the community concerned. It aims to produce community oriented health professionals who are able and willing to serve their communities and deal effectively with health problems at all levels of care. The overall goal of CBE is to improve the universal accessibility of basic health care through expanding HP students' notion of community health problems. To achieve this, CBE must consist of activities that utilize the community extensively, where not only students but also teachers, members of the community and representatives of other sector are actively engaged throughout the educational process. During last half a century, on one hand, CBE expanded from a handful of HPE institutes to hundreds of institutions worldwide, on other there remain growing concerns about the effectiveness and sustainability of $\mathrm{CBE}$. The health care challenges, for which $\mathrm{CBE}$ was introduced, are not 
only prevalent but in some places have exacerbated, requiring new roles and competences from health professionals. Competency is defined as the blend of skills, abilities, and knowledge needed to perform a specific task. Use of competency as an approach to education originated from elementary education and vocational training which was soon introduced into HPE as well. The competency approach is well adopted in HPE because of the clear relationship between student performance and work force expectations. So far the focus in competency models in HPE is on clinical care at tertiary or secondary settings and its affinity with CBE is yet to be studied in-depth.

While CBE and competency approach as separate constructs have previously been studied extensively, to examine these two together is central to this thesis which seeks to answer: (a) What CBE related competencies are identified in the literature? (b) Do community settings require different sets of competencies for physicians and registered nurses? (c) What variations exist in the competencies of physicians and registered nurses working in rural, urban and semi urban community settings? (d) What variations exist in the competencies of physicians and registered nurses working in community facilities run by the government, non-governmental organisations (NGOs) or universities? (e) What are perceptions and practices of faculty members' in relation to the implementation of $\mathrm{CBE}$ in their institutions? 


\section{CHAPTER 2: COMPTENECIES fOT UNDERGRDAUTE CBE PROGRAM FOR THE HEALTH PROFESSIONS-A SYTEMATIC REVIEW}

Community Based Education (CBE) along with competency approach is increasingly becoming popular; however, there appears to be a lack of evidence on $\mathrm{CBE}$ competencies for the undergraduate curriculum. Therefore a systematic review was carried out to identify and categorize these. We searched MEDLINE, CINAHL and ERIC databases published in English between January 2000 and December 2009 that described an explicit relationship between "competency" and curricular approaches. Studies where competency was referred to as outcomes or which were concerned with postgraduate or on-line education, were excluded from the review. Following the guidelines of Best Evidence Medical Education (BEME), 19 original, peer reviewed journal articles were included for final review.

Most articles reported that competencies were derived from already existing competency models. A few places had designed their own, with only one article reported full integration of CBE competencies throughout the curriculum. The competencies identified were grouped into six themes identified as Public health; Cultural Competence; Leadership \& Management; Community Development; Research and Generic Competencies. Additionally, a number of clinical competencies were also found to be overlapping with CBE.

The chapter concluded that the literature on CBE competencies is limited in number and lacks representation of lower income countries. To expand the efforts to other institutions and countries, core competencies for CBE 
must be recognized and disseminated widely for its integration in health professionals' curriculum

\section{CHAPTER 3: DOES COMMUNITY HEALTH CARE REQUIRE DIFFERENT COMPTENCIES FROM PHYSICINS AND NURSES?}

Utilizing the professional competencies identified in the previous chapter, we investigated the use of these in the practice of community care. We explored recognition of these competencies by various stakeholders including the health professionals themselves and the factors that encourage or impede competency based practices of physicians and nurses in various settings. The study was conducted in twelve primary and secondary health care facilities, managed either by university, government or non-governmental organizations of two major cities of Pakistan - Karachi and Islamabad - and its surrounding towns/villages. This study examined the specific tasks of health providers and variations in their competencies in a context where there is a structural scarcity of health professionals. In-depth Interviews were done with 11 Physicians and 6 Registered Nurses (RNs) working in rural, semi urban and urban areas and their job descriptions were reviewed.

The most frequently mentioned competency for physicians is "direct patient care" and for nurses it is either "public health" or "administration". Location of health facility or level of care was not reported as demanding different competencies, however depending on the employer the required competencies do vary. The critical factors in 
determining the tasks performed by health providers were availability of a functional health team and the preparation of health providers for CBE competencies. They have also provided some important insights into the practice of community health provision informing us that in Pakistan, firstly, not many health professionals opt to work in community settings, and those who do are not perceived as competent to provide the full range of services required in a community setting. Secondly, emphasis was only on curative care; health promotion and prevention were not of priority concern. Thirdly, health professionals have learned most tasks over time either through formal in-service training or informally by observing colleagues participants, during undergraduate training they reported having been exposed to and by practicing to provide curative care to patients coming to hospitals. Finally, working in rural areas in general, and for government run facilities in particular, were identified as factors adding to the challenge of opting for work in community settings. The specific tasks of physicians and nurses working in community settings provide a useful framework to analyze competencies, and can help educators revisit the curricula and instructional designs.

\section{CHPATER 4: COMPTENCE, COMMITMENT AND OPPORTUNITY: VIEWS OF FACULTY ON CBE}

Alignment and balance between the three elements - institutional structure, curriculum and faculty members - of Health professional education institutions are fundamental to accomplishing optimum integration of CBE. We conducted a study to specifically explore the third element, that is: faculty members' perspectives and practices in relation 
to the implementation of $\mathrm{CBE}$ in their respective institutes. Six institutes which were either part of a medical university or of a faculty of health sciences of a general university financed and governed by the public sector, armed forces or private sectors from two cities of Pakistan were selected. We conducted twelve focus group discussions and four key informant interviews. All data was analysed using qualitative research software. The participants in the study commented on various aspects of CBE and its implementation including barriers set by institutional structure, the curriculum and their own preparation for CBE.

The availability of resources for teaching, service or research activities in the community appeared to be a major problem in all types of institutions. Community-based encounters were considered inadequate, having little relevance to the content that was taught. The participants in our study also mentioned that poor reward structures and low priority for community service as well as ambiguity concerning expectations and policies constitute structural barriers. In relation to the curriculum, we found that community concepts were not connected with or integrated in other subjects or clinical training. Of the participants in our study more than half were not formally trained for CBE. There was also an absence of clarity regarding certain important concepts such as community participation; competencies for health professional students in general and for CBE in particular. Their description of these competencies underscored the view of CBE as a mere 'add on' to the 'core' curriculum. Moreover, lack of commitment, appreciation of and resistance to CBE 
appeared to permeate opinion at all levels - regulatory bodies, institutional heads and faculty members.

Our findings suggest that $\mathrm{CBE}$ continues to pose a real challenge, and unless institutional structure, curriculum and faculty are strengthened and brought into alignment, this situation is unlikely to change. Considering that informed and engaged faculty members are crucial to the success of any HPE endeavour, it is imperative to invest not only in their training but also in creating mechanisms to harness their interest and enthusiasm to advance the promotion and delivery of $\mathrm{CBE}$.

\section{Chapter 5: ACADEMIC LEADERSHIP AND INSTITUTIONAL CULTURE FOR CBE: ANEXPLORATION OF INSTITUTIONAL PRACTICES AND PRIORTIES IN PAKISTAN}

CBE perspectives and practices of faculty members at HPE institutes reported in previous work suggest a need for further research on the attitudes, beliefs and assumptions of the academic leaders and institutional culture towards CBE. Moreover, though leadership and institutional culture constructs have been well studied, their importance to the field of higher education in general and HPE in particular has not been established The purpose of the research presented in Chapter 5 was therefore to explore perspectives of academic leaders and the culture of HPE institutes.

A purposive sample of seven Academic Heads (AHs) - deans /principals of HPE institutes (medical and nursing colleges) and six heads of community departments (HODs)was drawn from the list of HPE institutes in Pakistan 
where undergraduate programs for both professions -medicine and nursing- were taught. These represented a good mix of seven public and private HPE institutes from the four major cities of Pakistan.

We designed two web-based questionnaires to elicit responses regarding opinions, beliefs and practices of respondents in the areas of three basic functions of a university/teaching institute: (a) Teaching and learning, (b) Research, and (c) Service regard to CBE. In addition, policies for promotion, reward structures and priorities for allocating resources in support to community health services and CBE were explored as proxy to identify the (CBE) culture of HPE institutions.

The practices, experiences and recommendations as shared by academic leaders evidently indicated that their belief of community service and their notion of contribution were not translated into their institutional practices, policies and priorities. We found a dissonance between the opinions \& beliefs and the practice within faculty, and policies of institutions as communicated by academic heads. In a number of responses we also found that faculty practices, student activities and research were not aligned with the overall mission of HPE or goals of CBE. Faculty and student activities at the community field sites were limited to consult patients or, at most, conducting health teaching sessions. Community research was not common, and where a few researches were done these were in isolation. With respect to the reward structures and promotion criteria, teaching and publication were higher on the promotion criteria than community service and community based researches. These were not even a priority concern of the institutes. We 
also found that, there were not many faculty development activities targeted at managing perceptions and creating an academic culture conducive to CBE Moreover, a lack of role models was identified as one of the major impediments in the implementation of CBE.

Finally, the study also identified that academic leaders have contributed to move CBE agenda in their institute. However, it is timely and necessary now to move on to the next level of institutional building to develop a culture that could promote and encourage aims and principles of CBE.

\section{CHAPTER 6: GENERAL DISCUSSION}

In chapter 6 we discussed the conclusions with regard to the need of future research and practical implications of $\mathrm{CBE}$ and competency approach in the undergraduate medical and nursing programs.

On CBE competencies, research is needed on how CBE competencies are perceived by faculty members, students and communities; for example, how to assess competencies in community settings and to quantitatively examine the impact of the competency approach in CBE on graduates' career choice and practice. There is also a need to investigate the relationship between academic leadership and institutional culture and to explore how and why an academic leader's behavior, if at all, affects institution's prevalent cultural values, also examining the role of academic leadership in harnessing institutional culture in support of community needs.

In terms of implications of the findings of this thesis on practices and policies within the sphere of HPE and outside that is on health systems we specifically refer to: 
- Strengthening and engaging leadership for an effective change of culture; we recommend a leadership program to be implemented in two phases: for the short-term, programs to develop young/new leadership which can take forward the agenda of change. For the long term, a reform in academic leadership is needed including structural (policies, governance and stewardship) cultural (norms, routine and values), managerial (rules and regulations) elements, and relationship building within circles of HPE institutes, the broader healthcare system and its health care providers, policy makers and community representatives.

- Introducing a comprehensive faculty development program and methods that encompass cognitive and affective domains in addition to enhancing knowledge such as experiential learning opportunities, on-going peer coaching and mentorships, as well as self-directed learning for orienting new faculty members as well and built into the continuous education programs.

- Developing roles and career structures for community health nurses and their specific roles for community settings to be reflected in their undergraduate curriculum; this implication is of particular significance to the healthcare system in Pakistan. 
Samenvatting 


\section{Hoofdstuk 1: Introduktie}

Dit proefschrift gaat over Community Based Education (CBE) in medische en verpleegkundige opleidingen. De meeste literatuur over CBE beschrijft de karakteristieken en doelen. Sinds een paar jaar verschijnen er artikelen waarin de verschillende modellen van CBE worden geëvalueerd . Er is echter weinig inzicht in de integratie van CBE in het gezondheidszorgonderwijs en over de professionele competenties die nodig zijn om effectief te werken in de community . In dit proefschrift is onderzoek gedaan naar de structuren, perspectieven en de praktijk van $\mathrm{CBE}$ in gezondheidszorgopleidingen en de professionele competenties van afgestudeerden die in de community werken in Pakistan.

CBE is een onderwijsbenadering die zowel op groepen als op individuen is gericht, waarbij rekening gehouden wordt met de gezondheidszorgnoden in de community. Het doel van CBE is om community oriented health professionals op te leiden die hun communities kunnen en willen dienen en in staat zijn om effectief om te gaan met gezondheidszorgproblemen op alle niveaus van zorg. De ambitie van CBE is de toegankelijkheid van basale zorg verbeteren door het besef van community health problems bij studenten te vergroten. Daarom wordt bij CBE de community intensief benut. Niet alleen de studenten maar ook de docenten, leden van de community en vertegenwoordigers van andere sectoren zijn actief betrokken in het hele onderwijsproces. De laatste 50 jaar is CBE uitgebreid van een handvol instituten tot honderden over hele wereld. Er zijn nog wel zorgen over de effectiviteit en de duurzaamheid van CBE. De gezondheidszorgproblemen waarvoor CBE is geïntroduceerd bestaan nog 
steeds en zijn in sommige landen zelfs verergerd, dat betekent nieuwe rollen en competenties voor de werkers in de zorg. Competenties bestaan uit vaardigheden, kunde en kennis om een special taak op te lossen. Competenties komen uit het basisonderwijs en zijn inmiddels ook in het gezondheidszorg onderwijs ingevoerd. De competentie benadering sluit goed aan bij het onderwijs in de zorg omdat er een duidelijke relatie is tussen de prestaties van de student en de verwachting in het veld. Tot nu toe is er vooral aandacht voor competenties in de tertiaire en secundaire zorg, competenties in CBE moeten nog verder bestudeerd worden.

Hoewel CBE en de competentie benadering apart uitgebreid zijn onderzocht, worden ze in dit proefschrift gezamenlijk onderzocht. Er worden antwoorden gezocht op de volgende vragen: (a) Welke CBE gerelateerde competenties zijn bekend uit de literatuur? (b) Zijn er verschillenden competenties voor artsen en verpleegkundigen in de community ? (c) Welke variaties bestaan er in de competenties van artsen en verpleegkundigen die werken in rurale, stedelijke of semistedelijke communities? (d) Welke variaties bestaan er in de competenties van artsen en verpleegkundigen die werken in communities georganiseerd door de regering, non-governmental organisations (NGOs) of door universiteiten? (e) Wat zijn de percepties van stafleden en wat gebeurt er in de praktijk met betrekking tot de implementatie van $C B E$ in de onderwijsinstellingen? 


\section{HOOFDSTUK 2: Competencies for Undergraduate Community Based Education for the Health Professions - A Systematic Review}

Community Based Education ( $\mathrm{CBE}$ ) en de competentie benadering is toenemend populair. Er lijkt weinig bewijs voor de CBE competenties in de opleidingen. Een systematische review is gedaan om te zoeken naar informatie over dit onderwerp. MEDLINE, CINAHL and ERIC databases werden doorzocht, om Engelse artikelen te vinden, die gepubliceerd waren tussen januari 2000 and december 2009 en die een expliciete relatie legden tussen competentie en curriculumbenaderingen. Studies waar competenties als outcomes werden beschouwd of die over de vervolgopleidingen of online onderwijs gingen werden niet geincludeerd. Op geleide van de regels van Best Evidence Medical Education (BEME), werden 19 originele, peer reviewed artikelen geincludeerd voor de review.

De meeste artikelen rapporteerden dat de competenties afgeleid waren van al bestaande modellen. Soms ging het over zelf ontwikkelde competenties en er was maar een artikel waar volledige integratie van CBE competenties door het hele curriculum was gerealiseerd. De geidentificeerde competenties warden in ondergebracht in zes thema's :

Public health; Cultural Competence; Leadership \& Management; Community Development; Research en Generic Competencies. Een aantal klinische competenties vertoonden overlap met CBE.

De literatuur over CBE competenties is beperkt en lage lonen landen zijn weinig vertegenwoordigd. De competenties voor CBE moeten herkend 
worden en naar andere landen worden verspreid om goede integratie van CBE met het curriculum mogelijk te maken.

\section{Hoofdstuk 3: Does community health care require different competencies from physicians and nurses?}

De vraag was of de geïdentificeerde competenties in hoofdstuk 2 gebruikt werden in de praktijk. Bij verschillende stakeholders inclusief de gezondheidszorgers zelf werd nagegaan of ze de competenties herkenden. Ook werd nagegaan welke belemmerende of bevorderende factoren artsen en verpleegkundigen herkenden om competentie gericht te werken in verschillende situaties. Het onderzoek werd uitgevoerd in 12 primaire en secundaire gezondheidszorg instellingen van de regering, een NGO of universiteit in twee grote steden in Pakistan - Karachi and Islamabad - en dorpen en steden in de omgeving. In deze studie is onderzocht wat de specifieke taken van gezondheidszorgwerkers zijn en ook de variatie in hun competenties in een context waar een gebrek aan gezondheidszorgwerkers is.Diepte interviews werden gedaan met 11 artsen en 6 geregistreerde verpleegkundigen, die in rural, semi stedelijke en stedelijke omgevingen werkten. Ook werden hun functieomschrijvingen beoordeeld .

De meest frequente competentie van artsen is"patiëntenzorg" en voor verpleegkundigen is "public health"of" administratie". De plek van de faciliteit werd niet genoemd als oorzaak voor verschillen in de gevraagde competenties, hoewel de werkgever wel invloed op de gewenste competenties. Als kritische factoren bij het bepalen van de taken werden genoemd de beschikbaarheid van een functionerend 
gezondheidszorgteam en de voorbereiding van gezondheidszorgwerkers op CBE. De interviews hebben ook inzicht gegeven in de praktijk van zorgverlening in de communities in Pakistan: Er zijn niet veel gezondheidszorgwerkers die in de community willen werken en diegene die het doen worden als niet competent beschouwd om alle taken te vervullen; $\mathrm{Er}$ was vooral aandacht voor curatieve zorg, gezondheidsbevordering en preventie werden niet als prioriteit gezien; gezondheidszorgwerkers hebben de meeste taken in de loop van de tijd geleerd door hetzij formele training of door collega's te observeren. Ze vertelden dat ze in hun basisprogramma vooral bezig waren met curatieve zorg in ziekenhuizen; het werken in rurale gebieden en het werken in faciliteiten, die door de regering werden aangestuurd waren factoren die een uitdaging vormden voor het werken in de community. De specifieke taken van artsen en verpleegkundigen die in de community werkten, zijn een bruikbaar framework om competenties te analyseren en kan helpen om onderwijsprogramma's te verbeteren zowel wat betreft het curriculum als het ontwerp van het programma.

\section{Hoofdstuk 4: Competence, Commitment and Opportunity: Views of faculty on Community-Based Education (CBE)}

Afstemming en balans tussen de elementen: structuur, curriculum en stafleden in gezondheidszorginstellingen is cruciaal om CBE goed in programma's te integreren. In dit hoofdstuk wordt een studie beschreven naar het derde element, de stafleden. De percepties van stafleden en 
praktische uitwerking van de implementatie van CBE in hun opleidingen. Zes opleidingen, die deel uitmaakten van een faculteit Geneeskunde of Gezondheidswetenschappen, publiek, privaat of van het leger in twee steden in Pakistan werden geselecteerd. Er werden 12 focusgroepen en vier interviews gehouden. De data werden geanalyseerd met software voor kwalitatief onderzoek. De deelnemers aan de studie werden vragen gesteld over verschillende aspecten van $\mathrm{CBE}$ en de implementatie inclusief de barrières van structuur en curriculum. Ook werd hen gevraagd naar hun eigen voorbereiding op CBE.

De beschikbaarheid van middelen voor onderwijs, dienstverlening en onderzoek in de community is het grootste probleem in alle opleidingen. De bezoeken in de community warden beschouwd als niet adequaat en ze zijn niet erg relevant voor de inhoud van het onderwijs. De deelnemers aan ons onderzoek noemden ook de slechte beloning en de lage prioriteit voor dienstverlening aan de community. De verwachtingen en het beleid over de communities is niet consistent en wordt gezien als een structurele barrière. De concepten over de community waren niet verbonden of geïntegreerd met andere delen van het curriculum . Meer dan de helft van onze deelnemers was niet formeel getraind in CBE. $\mathrm{Er}$ was geen duidelijkheid over belangrijke concepten zoals participatie in de community, competenties voor gezondheidszorgwerkers in algemene zin en specifiek voor CBE. Uit de beschrijvingen blijkt dat CBE wordt gezien als een toevoeging aan het kerncurriculum. Er was een gebrek aan betrokkenheid, waardering en weerstand tegen CBE op alle niveaus. 
Uit onze bevindingen blijkt dat CBE op een goed manier uitvoeren nog een grote uitdaging is. Als de structuren, het curriculum en de staf niet op een lijn komen, zal dat waarschijnlijk ook niet veranderen. Omdat goed geïnformeerde en betrokken stafleden cruciaal zijn voor het succes, is het aan te raden om te investeren in training van de staf en mechanismen te creëren om hun enthousiasme voor het versterken en uitvoeren van CBE te stimuleren.

\section{Hoofdstuk 5: Academic Leadership and Institutional Culture for Community Based Education: An exploration of institutional practices and priorities in Pakistan}

Uit eerdere hoofdstukken blijkt dat het nodig is om verder onderzoek te doen naar attitudes, overtuigingen en meningen over CBE van de leidinggevenden en de cultuur rondom CBE. In algemene zin zijn leiderschap en cultuur wel bestudeerd, maar het belang voor het gezondheidszorgonderwijs heeft nog niet zoveel aandacht gekregen. Het doel van deze studie was om de perspectieven van leidinggevenden en de cultuur inde opleidingen te onderzoeken.

Zeven leidinggevenden van geneeskunde en verpleegkunde opleidingen en zes hoofden van community afdelingen werden benaderd voor het onderzoek. Zij vormden een goede steekproef van zeven publieke en private instituten in de vier grote steden in Pakistan.

Er werden twee web-based vragen lijsten ontworpen om informatie te krijgen over meningen, overtuigingen en over de praktijk op het gebied van de drie basale taken van een universiteit/ opleidingsinstituut: a) 
onderwijs en leren, b) onderzoek en c) dienstverlening naar de community. Om een beeld te krijgen van de (CBE) cultuur in de instellingen werden vragen gesteld over promotiebeleid, beloningstructuur en prioriteiten voor de middelenverdeling om dienstverlening in de community en CBE te ondersteunen.

De meningen en het gevoel van bijdragen aan de dienstverlening aan de community van de leidingegevenden bleek niet vertaald te worden in het beleid en de prioriteiten. De activiteiten van de staf, de studenten en het onderzoek waren niet afgestemd met de missie van het gezondheidszorgonderwijs of met de doelen van CBE. De activiteiten van staf en studenten in de community waren beperkt tot patiëntenzorg of soms onderwijs over gezondheid. Onderzoek in de community was ongebruikelijk, soms was er geisoleerd onderzoek. Onderwijs en publiceren waren belangrijker voor de carrière dan dienstverlening en onderzoek in de community. Deze laatste waren niet eens een prioriteit van de instellingen. Er waren nauwelijks activiteiten voor stafleden om een academische cultuur rondom CBE te creëren. Ook bleek er een duidelijk gebrek aan rolmodellen te zijn en dit werd ook gezien als een rem op de implementatie van CBE.

De leidinggevenden hebben wel geprobeerd om CBE meer op de agenda in hun opleidingen te krijgen. De tijd is rijp en het is nu nodig om een cultuur te ontwikkelen waarin CBE gestimuleerd kan worden.

\section{Hoofdstuk 6: General Discussion}

In hoofdstuk 6 worden de conclusies besproken wat betreft de noodzaak voor verder onderzoek en de praktische implicaties van CBE en de 
competentie benadering in de basisopleiding voor artsen en verpleegkundigen.

Wat betreft CBE competenties is onderzoek nodig naar hoe deze competenties worden ervaren door stafleden, studenten en de communities. Voorbeelden : hoe moeten competenties in de community getoetst worden en hoe kan de impact gemeten worden van de competentiebenadering op de carrièrekeuze en de praktijk van afgestudeerden? Ook moet de relatie tussen academisch leiderschap en de institutionele cultuur onderzocht worden. Voorbeelden: heeft het gedrag van een leider invloed op de cultuur, hoe werkt dat en waarom en wat is de rol van academisch leiderschap in het versterken van de de cultuur om de noden in de community te ondersteunen?

Wat betreft de implicaties van de bevindingen uit dit proefschrift voor de praktijk en het beleid, in gezondheidszorgonderwijs en op het gezondheidszorgsysteem hebben we de volgende aanbevelingen:

- Voor een effectieve cultuurverandering moet het leiderschap versterkt worden. We bevelen aan dat het leiderschap programma geïmplementeerd wordt in twee fasen.Een korte termijn benadering voor jonge en nieuwe leiders om de verandering op gang te brengen. Voor de langere termijn is een herziening van academisch leiderschap noodzakelijk . Hierbij zijn structurele ("policies, governance and stewardship") culturele ("norms, routine and values"), managerial ("rules and regulations") elementen belangrijk. Daarnaast moeten relaties ontwikkeld worden met instituten voor 
gezondheidszorgonderwijs, met het gezondheidszorgsysteem , zorgverleners, beleidsmakers en vertegenwoordigers van de communities.

- Introduceer een programma voor de training van stafleden en bested aandacht aan methoden die zowel het cognitive en affective domein bevatten om zo de kennis te vergroten, zowel voor nieuwe stafleden als voor nascholing. Voorbeelden hiervan zijn experientieel leren, longitudinale peer coaching, mentorschappen en self-directed learning .

- Ontwikkel rollen en carrière mogelijkheden voor verpleegkundigen in de community. De specifieke rollen in de community moeten aan de orde komen in de basisopleiding. Dit is met name van belang voor het gezondheidszorgsysteem in Pakistan. 


\section{SHE DISSERTATION SERIES}

The SHE Dissertation Series publishes dissertations of PhD candidates from the School of Health Professions Education (SHE) who defended their PhD theses at Maastricht University. The most recent ones are listed below. For more information go to: www.maastrichtuniversity.nl/she.

Jippes, M. (01-02-2013) Culture matters in medical schools: How values shape a successful curriculum change

Duvivier, R. J. (12-12-2012) Teaching and Learning Clinical Skills. Mastering the Art of Medicine

De Feijter, J.M. (09-11-2012) Learning from error to improve patient safety

Prescott, L. (09-11-2012) Ensuring the Competence of Dental Practitioners through the Development of a Workplace-Based System of Assessment

Cilliers, F.J. (05-09-2012) The Pre-assessment Learning Effects of Consequential Assessment: Modeling how the Examination Game is Played

Spanjers, I. A.E. (05-07-2012) Segmentation of Animations: Explaining the Effects on the Learning Process and Learning Outcomes

Al-Kadri, H.M.F. (28-06-2012) Does Assessment Drive Students' Learning?

Leppink, J. (20-06-2012) Propositional manipulation for conceptual understanding of statistics

Van Zundert, M.J. (04-05-2012) Conditions of Peer Assessment for Complex Learning

Claramita, M. (30-03-2012) Doctor-patient communication in a culturally hierarchical context of Southeast Asia: A partnership approach 
Kleijnen, J.C.B.M. (21-03-2012) Internal quality management and organizational values in higher education

Persoon, M.C. (19-01-2012) Learning in Urology; The influence of simulators and human factors

Pawlikowska, T.R.B. (21-12-2011) Patient Enablement; A Living Dialogue

Sok Ying Liaw, (14-12-2011) Rescuing A Patient In Deteriorating Situations (RAPIDS): A programmatic approach in developing and evaluating a simulation-based educational program

Singaram, V.S. (7-12-2011) Exploring the Impact of Diversity Factors on Problem-Based Collaborative Learning

Balslev, T. (24-11-2011) Learning to diagnose using patient video cases in pediatrics: Perceptive and cognitive processes

Widyandana, D. (19-10-2011) Integrating Pre-clinical skills training in skills laboratory and primary health care centers to prepare medical students for their clerkships

Durning, S.J. (09-09-2011) Exploring the Influence of Contextual Factors of the Clinical Encounter on Clinical Reasoning Success (Unraveling context specificity)

Govaerts, M.J.B. (08-09-2011) Climbing the Pyramid; Towards Understanding Performance Assessment

Stalmeijer, R. E. (07-07-2011) Evaluating Clinical Teaching through Cognitive Apprenticeship.

Malling, B.V.G. (01-07-2011) Managing word-based postgraduate medical education in clinical departments

Veldhuijzen, J.W. (17-06-2011) Challenging the patient-centered paradigm: designing feasible guidelines for doctor patient communication. 
Van Blankenstein, F. (18-05-2011) Elaboration during problem-based, small group discussion: A new approach to study collaborative learning.

Van Mook, W. (13-05-2011) Teaching and assessment of professional behavior: Rhetoric and reality.

De Leng, B. (8-12-2009). Wired for learning. How computers can support interaction in small group learning in higher education.

Maiorova, T. (29-05-2009). The role of gender in medical specialty choice and general practice preferences.

Bokken, L. (04-03-2009). Innovative use of simulated patients for educational purposes.

Wagenaar, A. (18-09-2008). Learning in internships. What and how students learn from experience.

Driessen, E. (25-06-2008). Educating the self-critical doctor. Using portfolio to stimulate and assess medical students' reflection.

Derkx, H. (18-06-2008). For your ears only. Quality of telephone triage at out-of-hours centers in the Netherlands.

Niessen, Th. (30-11-2007). Emerging epistemologies: making sense of teaching practice.

Budé, L. (05-10-2007). On the improvement of students' conceptual understanding in statistics education.

Niemantsverdriet, S. (26-07-2007). Learning from international internships: A reconstruction in the medical domain.

Marambe, K. (20-06-2007). Patterns of student learning in medical education - A Sri Lankan study in traditional curriculum. 
Pleijers, A. (19-01-2007). Tutorial group discussion in problem-based learning.

Sargeant, J. (21-09-2006). Multi-source feedback for physician learning and change.

Dornan, T. (12-06-2006). Experience-based learning.

Wass, V. (12-05-2006). The assessment of clinical competence in high stakes examinations.

Prince, K. (21-04-2006). Problem-based learning as a preparation for professional practice. 